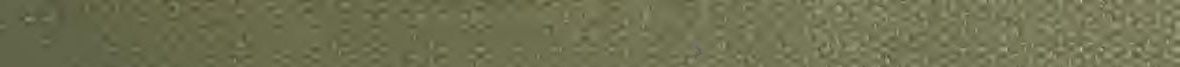

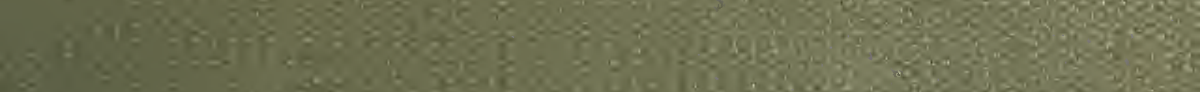

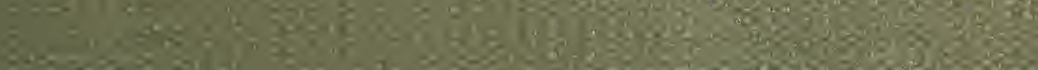

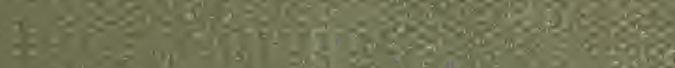

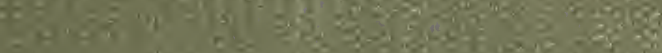

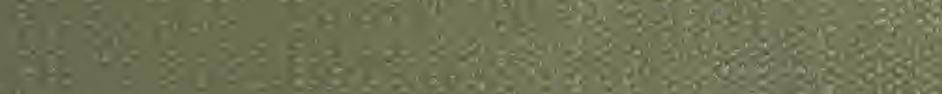

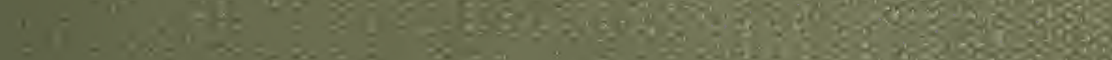

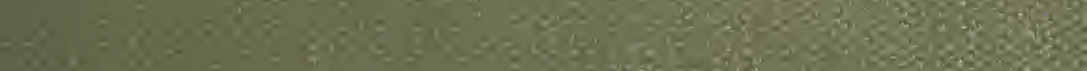

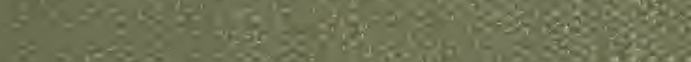

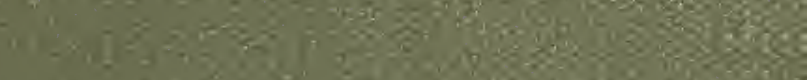

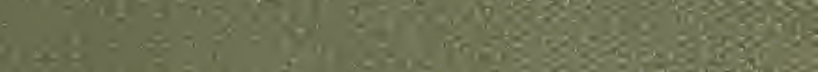

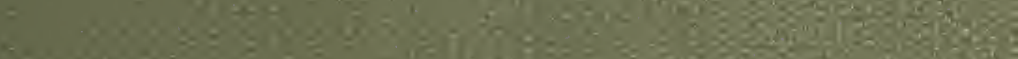

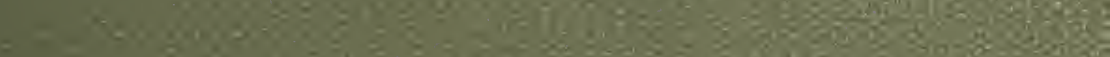

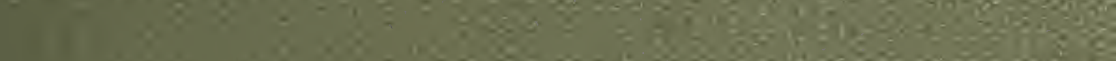

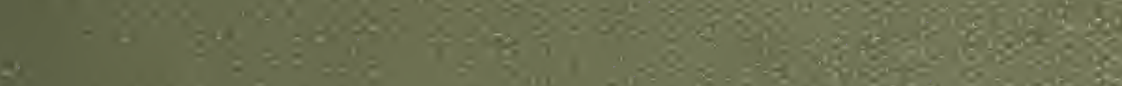

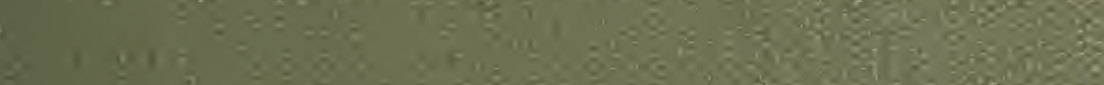

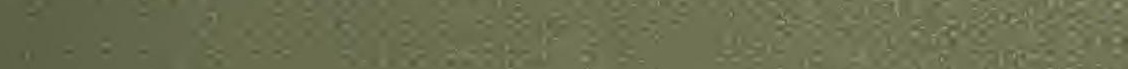
a.

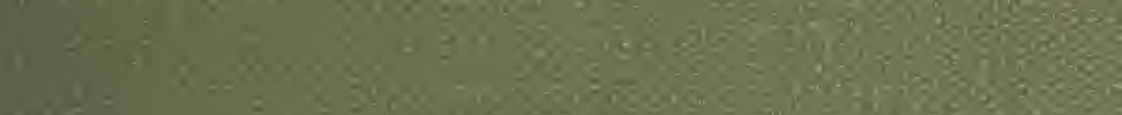

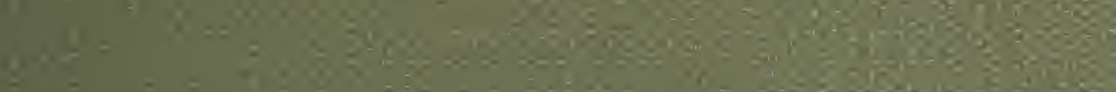

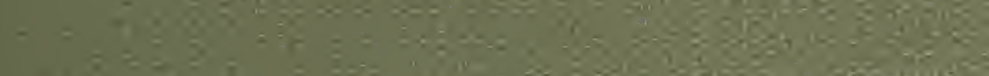

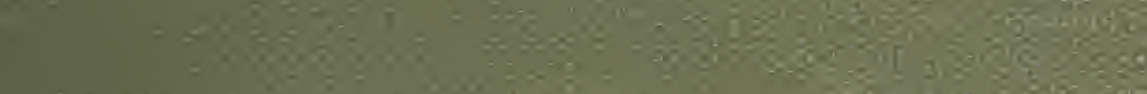

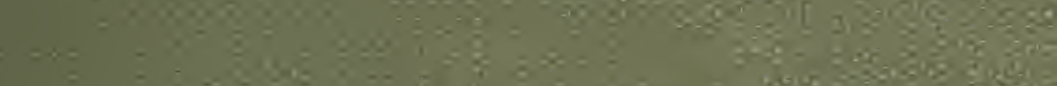

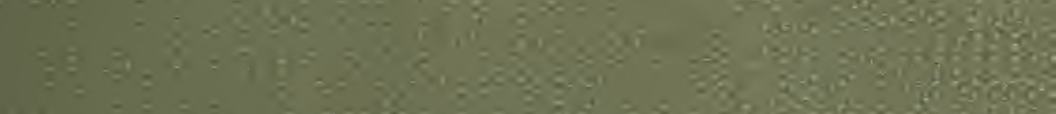

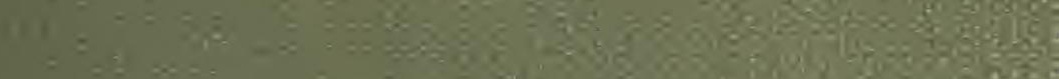
a

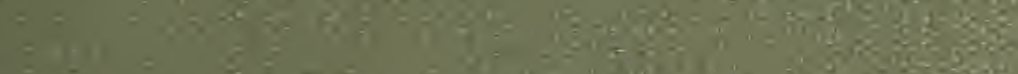

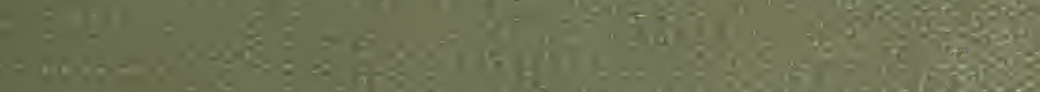

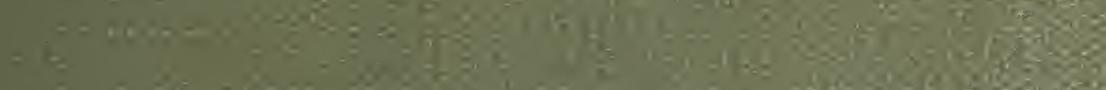

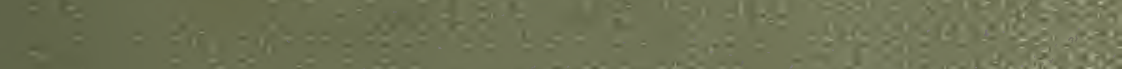

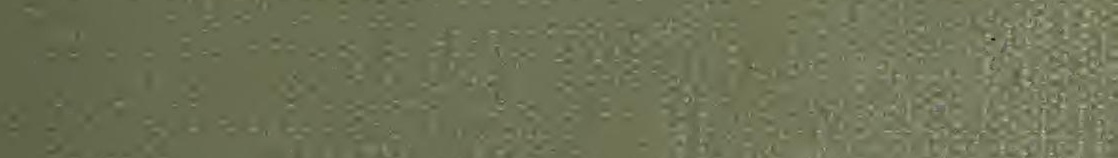

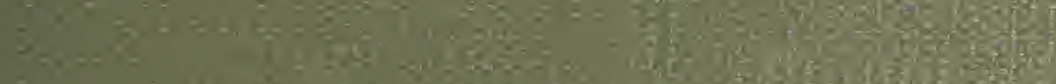

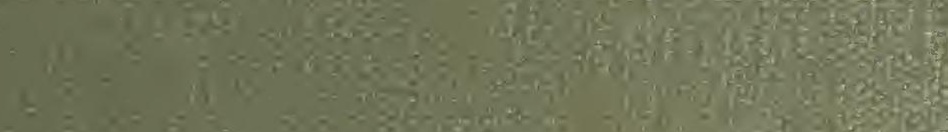

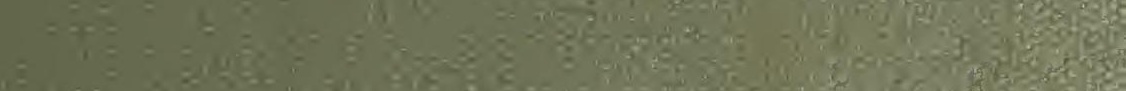

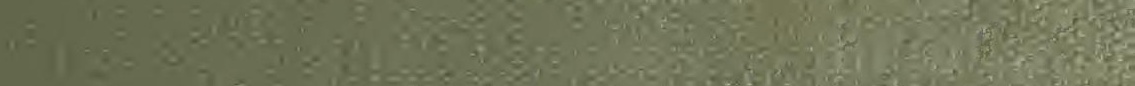

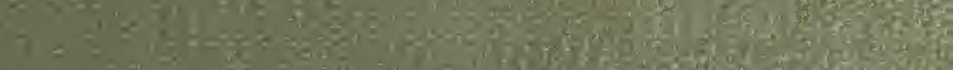

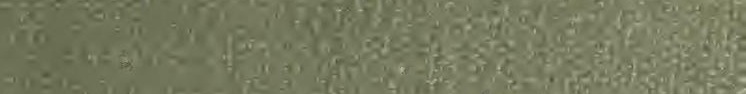

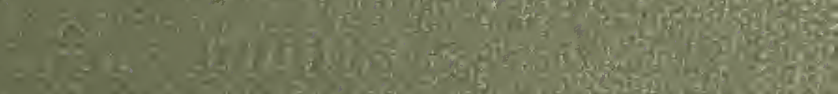

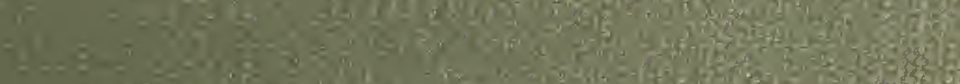

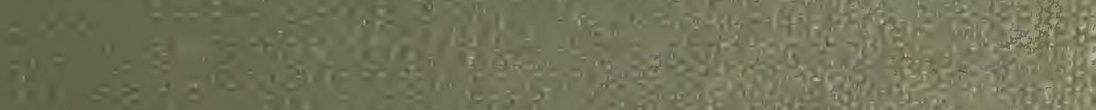

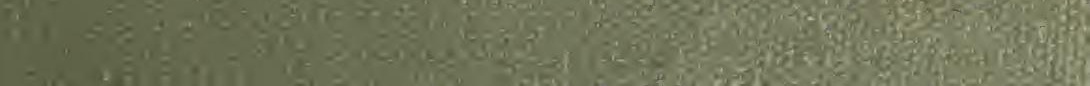




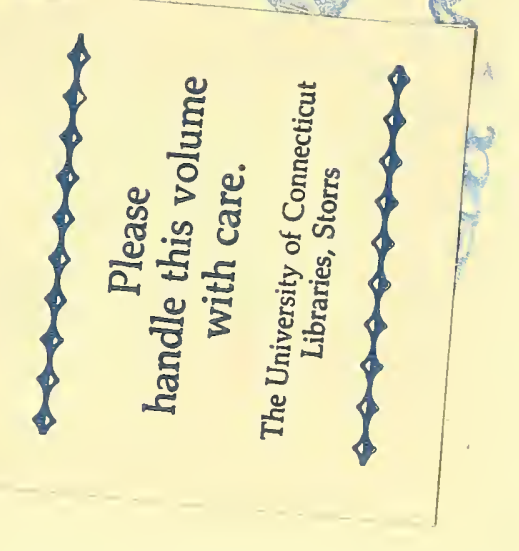

hbl, stx

SD $397 . \mathrm{C} 7 \mathrm{H} 3$

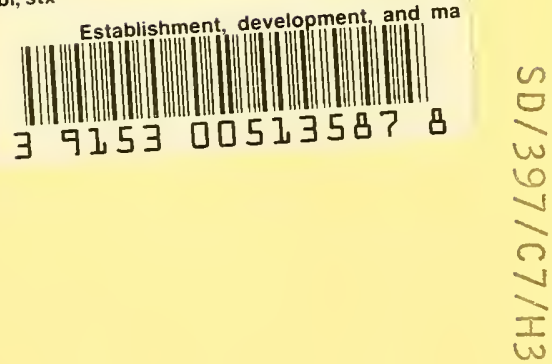




Digitized by the Internet Archive in 2011 with funding from

Boston Library Consortium Member Libraries

http://www.archive.org/details/establishmentdev00hawl 



\section{ESTABLISHMENT, DEVELOPMENT, AND MANAGEMENT OF CONIFER PLANTATIONS IN THE ELI WHITNEY FOREST, NEW HAVEN, CONNECTICUT}

BY

RALPH C. HAWLEY

Morris K. Jesup Professor of Silviculture, Yale University

and

HAROLD J. LUTZ

Associate Professor of Forestry, Yale University

NEW HAVEN

Yale University

I 943 


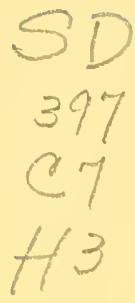

The publication of the results of this investigation was made possible by the Forest Production Research Fund at Yale University. 


\section{CONTENTS}

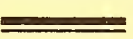

INTRODUCTION

CLIMATIC, PHYSIOGRAPHIC, AND ECONOMIC FACTORS CONTROLLING FOREST PLANTING

PLANTATION ESTABLISHMENT

Choice of species

Seed source

Pure versus mixed plantations

Growing the nursery stock

Planting methods

Spacing

Planting site in relation to species

NATURAL CYCLE OF DEVELOPMENT

Creation of a forest canopy

Formation of a forest floor

Disappearance of the herbaceous vegetation $2 I$

Dying of the lower branches $2 \mathrm{I}$

Live-crown ratio 24

Crown spread, total height, and diameter of white and red pine in mixed and pure stands

Natural pruning

Differentiation into crown classes

Prediction as to ultimate natural course of development

EFFECT OF THE PLANTATIONS ON SOIL CONDITIONS

PROTECTION AGAINST AGENCIES THREATENING INJURY 4I

White pine blister rust

Fomes root fungus

Tympanis canker

White pine weevil

European pine shoot moth

Eastern spruce gall aphid

Mound-building ant

Wildlife

CULTURAL OPERATIONS TO INCREASE AMOUNT AND VALUE OF THE CROP

Release from overtopping vegetation

Artificial pruning of branches

Cost of pruning and financial return expected

Thinning

HARVEST OF THE MATURE TIMBER WITH PROVISION FOR ESTABLISHING A NEW CROP 


\section{ESTIMATED COSTS AND RETURNS OF GROWING PLANTED \\ WHITE PINE AND NORWAY SPRUCE \\ CONCLUSIONS

APPENDIX

\section{ILLUSTRATIONS}

Figures

I. Number of trees planted by years, IgOI to I940

2. Progress of closing of pine plantations

3. Arrangement of branches on a white pine tree

4. Profile through a mixed plantation

5. View showing arrangement used in a mixed plantation

6. Estimate of yields from pine plantations

Plates (placed at end of text)

I. Old-field planting site stocked principally with grasses and cedars.

2. White pine plantation, established 7 years, which has not quite closed.

3. A dense white pine plantation 23 years of age.

4. White pine plantation with protective border of live branches extending to the ground.

5. White pine plantation 28 years of age.

6. A 30-year-old Norway spruce plantation.

7. White spruce plantation 22 years old.

8. A I 4-year-old red pine plantation having an original spacing of 6 by 6 feet.

9. Red pine plantation 28 years of age.

Io. Red pine plantation 6 years old having an original spacing of 8 by 8 feet.

I I. Red pine plantation 12 years of age in which closure of crowns has recently taken place.

I2. Scotch pine plantation 24 years old.

I3. A mixed plantation of four species arranged in 9-tree units.

I4. Red oak established by direct seeding.

I 5. Red pine tree, Io years old, that has just been pruned to a height of 7 feet.

I6. Red pine tree, I 5 years old, that has been pruned to a height of I 7 feet.

17. A white pine tree pruned to a height of 18 feet in two operations.

18. Pruning by the saw and ladder method.

19. Two views through a pruned white pine branch stub.

20. Zone of clear wood formed over pruned branch stubs.

2I. A bark and pitch pocket enclosed on a completely covered white pine branch stub.

22. White pine plantation, 23 years of age, after a first thinning.

23. White pine plantation thinned 7 years ago.

24. Norway spruce plantation, 30 years old, after a first thinning.

25. Red oak established by direct seeding 35 years ago and recently thinned. 
ESTABLISHMENT, DEVELOPMENT, AND

\section{MANAGEMENT OF CONIFER PLANTATIONS IN THE ELI WHITNEY FOREST, NEW HAVEN, CONNECTICU'T}

\section{INTRODUC'TION}

SOON after the Yale School of Forestry was founded in Igoo reforestation on an experimental scale was begun by the School in parts of the Eli Whitney forest. ${ }^{\mathrm{x}}$ For the first nine years the total area reforested amounted to less than $5^{\circ}$ acres. In I909, planting on a larger scale by the New Haven Water Company was started in the Eli Whitney forest and has continued ever since, so that there are now approximately 2,800 acres of conifer plantations, forming 13 per cent of the total area. Experience in forest planting now has been accumulated over a 40-year period. Many of the plantations have been growing more than a quarter of a century and, while they have not passed through their entire life cycle from establishment to harvest, still they are old enough to furnish valuable indications as to the methods to be used and the results which can be expected from forest planting in southern New England. The bulletin has been prepared for the purpose of making this information available to other landowners interested in forest planting in this region or in other localities of similar character.

\section{CLIMATIC, PHYSIOGRAPHIC, AND ECONOMIC FACTORS CONTROLLING FOREST PLANTING}

F ACTORS such as climate, topography, and soils, together with the I social and industrial situation, strongly influence all forestry projects and among them forest planting. Hence, a brief consideration of these factors is needed to furnish a background for the detailed discussion of the subject which comes later. Southern Connecticut is situated on the seacoast between $4 \mathrm{I}$ and 42 degrees N. latitude. Although influenced by the ocean, the climate is continental, since the winds are chiefly from the southwest, northwest, and north. Rainfall over a long series of years averages approximately 4 inches a month throughout the year. There is,

I. A forest of approximately 22,000 acres, named after the Hon. Eli Whitney, Yale I869, located closely adjacent to New Haven, owned by the New Haven Water Company and managed under the direction of the Yale School of Forestry. 
however, a wide variation both in total annual precipitation and in its monthly distribution in different years. Variations of the latter type are of especial importance in the growing season. Occasional droughts which may occur in the spring, summer, or fall of any year affect the survival of young plantations as well as influence their rate of growth. The mean monthly temperature during the growing season varies from approximately 47 to 72 degrees Fahrenheit. The frost-free period averages 170 to Igo days in length. Periods of extreme cold in the winter are rare. Only once or twice during a Io-year period is the temperature likely to fall below zero for more than a few hours at a time on widely scattered days.

For a distance of 30 miles inland from the Connecticut coast the land lies mainly at levels of less than 100 to 500 feet above sea level with a few points rising to around 800 feet. It is, however, not a level plain, even slope, or uniform plateau but rather exhibits a variety of topography often changing abruptly in short distances. Originally all forested, the region was progressively cleared of forest until about I820 approximately only 25 per cent of the land area remained in forest. Subsequent to 1820 changing economic conditions caused much of the cleared land to be left unused for agricultural purposes with a consequent reversion to forest. This process and the reasons for it, applying as they do to the northeastern United States in general, have been too often discussed to need further attention. It is sufficient to state that at least 50 per cent of the land area in southern Connecticut is already in forest and many areas of unused agricultural land, formerly cropped or pastured, are on the verge of reverting to forest. These latter are the type of areas upon which most forest plantations in southern Connecticut have been established.

Land in southern Connecticut needs further classification for planting purposes on the basis of geology and soils. Three major groups of rocks may be recognized, namely the trap rock (dolerite) and sandstones of the Connecticut Valley lowland and the crystalline complex (gneiss, schist, granite) of the adjacent eastern and western upland.

Trap rock, in the form of sills and lava flows, is much more resistant to erosion than the weak sandstones and now projects as sharp ridges often 200 feet above the latter rocks. The tops of the trap rock ridges frequently have pockets of deep soil fairly well supplied with moisture because of the relatively impervious character of the underlying rock mass. Holyoke loam and very fine sandy loam, the principal soils derived from trap rock, are well supplied with plant nutrients but contain 
numerous roughly angular rock fragments. These soils usually are unsuited to agriculture owing to their pronounced slope and shallowness, or to the amount of rock which they contain. The forest on some of the areas underlain with trap rock was in early days cut off and the land pastured. Such areas were among the first to be abandoned and hence reverted naturally to forest. Trap rock areas are from the practicalstandpoint unplantable, because of the high rock content of the soil which makes the operation costly. Only a few of these areas have been planted in the Eli Whitney forest. It is better policy to allow such areas to restock by natural seeding.

The sandstones (together with some shales) are weaker than the associated trap rocks or the crystallines of the eastern and western uplands. Consequently, areas underlain by the former rocks now occupy positions of relatively low relief, the sandstones having been worn down by erosion during pre-glacial time. Sandstones and shales have supplied the parent materials for four important soils, namely, Cheshire and Wethersfield (developed from glacial till) and Manchester and Hartford (developed from alluvial deposits). Texturally these soils are sandy loams, fine sandy loams, or loams. A large proportion of the land with soils derived from sandstones was cleared and in agricultural use in earlier times. In fact many good fruit orchards and truck farms are still in operation on these lands. Thousands of acres have been abandoned for agricultural production, however, and these represent some of the best forest planting sites in the region.

Soils of the uplands lying to the east and west of the Connecticut Valley lowland are derived principally from non-calcareous crystalline rocks (schists, gneisses, granites). The most important soils, developed from deposits of glacial till, are the Gloucester, Brookfield, Hinsdale, and Maltby. All of these soils occur in areas of rough topography and, being fine sandy loams and loams, furnish good sites for planting. They are well drained, frequently shallow, and nearly always rocky. A very substantial acreage of land formerly used for agriculture, and now in the process of reverting to forest, is found in the areas of schists, gneisses, and granites.

Forest planting in the Eli Whitney forest has been done principally on land with soils derived from sandstone and the crystalline rocks because of the existence there of extensive non-forested areas unused for agriculture. Planting has been confined largely to non-forested lands since it was a logical first step to reforest the unused bare areas. From the stand- 
point of watershed protection it was desirable to establish forest stands on open areas in order to enhance the protective value of the watershed cover.

The old pastures and meadows, allowed to lapse from agricultural use, were of course generally not of such good quality as those retained in crops or pasture, but compared favorably with the lands never cleared of forest. In the Eli Whitney forest some lands of excellent agricultural quality which lie adjacent to reservoirs or streams have been planted to forest. Whether these lands are really any better for forest production than much of the natural forest area which was never cleared is open to question. Factors, such as freedom from stone, which are of paramount importance in agricultural production, may not detract from the fertility of the land for the growth of forests.

In summation, planting in the Eli Whitney forest has had as its primary objective the reforestation of the open lands which were not needed for administration or other purposes. Practically all such lands on this property not reserved for other purposes have now been planted, thus substantially completing the policy of reforestation originally contemplated.

Table I shows the areas in various land classes in the Eli Whitney forest as of January I, I94I, while Table 2 gives areas of the plantations arranged by species and age classes. Since there have been reductions in plantation areas during the last 40 years because of land sales, fires, and other causes, the figures in Table 2 do not give a complete record of the total amount of planting, but they do indicate the relative importance of the different species in the planting.

TABLE I. LAND CLASSIFICATION IN THE ELI WHITNEY FOREST

\begin{tabular}{lr}
\hline \multicolumn{1}{c}{ Land Class } & Acres \\
\hline Hardwood & $14,716.0$ \\
Hardwood swamp & $1,338.2$ \\
Hemlock-hardwood & 969.5 \\
*Pine & $2,860.2$ \\
Cedar swamp & 65.4 \\
Old fields & $1,106.5$ \\
Agricultural areas & 611.3 \\
Open swamp & 271.6 \\
Administrative and barren & 133.5 \\
\hline Total & $22,072.2$ \\
\hline
\end{tabular}

*Includes all plantations of conifers as well as a small area of naturally seeded pine. 


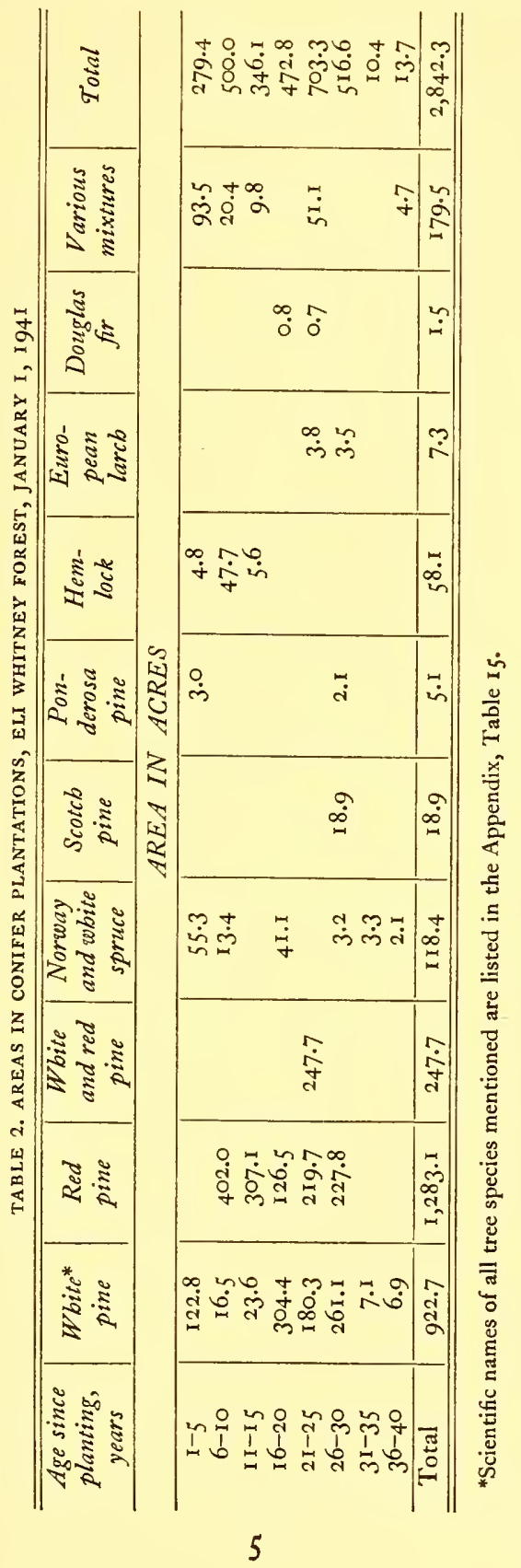




\section{PLANTATION ESTABLISHMENT}

\section{Choice of Species}

DLANTING in the Eli Whitney forest began in a period when conifers, particularly the pines and spruces, were in high favor as they still are. Eastern white pine, Scotch pine, and Norway spruce were at that time the three species principally used in northeastern United States. White pine was a natural choice because of its preëminent place as the leading timber tree in the Northeast. Scotch pine, in spite of being an exotic, was used because of the ease and cheapness with which seed could be secured, its ability to survive on dry. sites, and its remarkably fast growth in youth. Norway spruce, also an exotic, was favored because of cheap seed, ease of production in the nursery, and its high yield and value as a pulp and timber tree. It was natural that planting in the Eli Whitney forest should parallel the general trend of the regional movement. During the period Igor to 1908 white pine and Norway spruce were used principally, with a little Scotch pine and smaller quantities of red pine, northern white cedar, and red spruce.

In the years IgOI to I 910 , nursery production in the United States was insufficient to supply the demands for cheap stock for forest planting. Consequently for a few years forest nursery stock was imported from Europe. In I 909 planting was done with white pine stock imported from Germany. The same plan was followed in I910. Meanwhile a nursery had been started and in I I I stock from this nursery was ready for planting. Since then practically all the trees planted in the Eli Whitney forest have been grown in nurseries close to the forest. During the period IgI I to I 9 I 4 small quantities of Scotch pine were used each year. About this time it became possible to obtain seed of red pine in quantity and a change from Scotch to red pine was made. Foresters in the Northeast were alarmed around I9I I by the threat of the white pine blister rust to the native white pine. This led, in the Eli Whitney forest, to reducing the planting of white pine and increasing the proportion of red pine whenever seed of the latter species could be obtained. Eventually, after the problem created by the introduction of white pine blister rust was more accurately appraised and methods for its control developed, it became evident that planting of white pine need not be stopped. After 1930 the spread of the European pine shoot moth became so threatening to red pine plantations in the region along the Atlantic coast that planting of 
this species was discontinued. The last large planting of red pine was made in 1932.

Meanwhile the small experimental plantations of Norway and white spruce had developed so well, in spite of relatively slow growth compared to the pines during the first fifteen to twenty years after planting, that it now became evident spruce could be counted on to make good stands of timber in southern Connecticut. Experience over the years indicated also that the native white pine was one of the most reliable conifers to plant in this region. Forty years of experience leads to the conclusion that this species and Norway spruce, and probably white spruce also, are the best conifers for forest planting in southern Connecticut. Since I934 white pine and Norway spruce have formed an important part of the planting each year. During the period I933 to 1937, inclusive, eastern hemlock was planted to some extent, principally in mixture with white pine and Norway spruce. It is more difficult to obtain success with hemlock planted on old fields than it is with the pines and spruces and the species is commercially of less value.

The approximate number of trees planted in the period I90 I to I 940 arranged by species and years is shown in Table 3 . Red pine leads the list with white pine a close second. All other species combined make up only about one-third of the white pine total. A graphic representation of the data in Table 3 is given in Figure I. This brings out clearly the fluctuations in the planting program. It started slowly in the period Igo I to I9I I. During the 6 years I9I 2 to I9I 7 , inclusive, over 40 per cent of the total number of trees were planted. The decrease in I9I8, I9I9, and I920 was a consequence of the first World War in its effect on labor and seed supply. Planting increased again in I92 I but gradually decreased from that year until 1927 as the lands scheduled for planting were stocked. However, beginning in 1929 planting was started on newly purchased lands in the territory from North Branford eastward. The decrease in. 1933 and 1934 was caused by a sudden decision to stop the planting of red pine. The trend from 1935 through 1940 was a gradual decrease until at the present time, since 1940 , the planting is reduced to about 25,000 trees per year used in finishing odd corners, in refilling blanks in plantations previously established, or in stocking small areas of cutover forest.

Experience has also shown that successful stands of red oak can be established either by direct seeding or by planting (see Plate 14). Red oak is one of the most valuable of the hardwood timber species native to southern Connecticut. Many landowners may choose to plant red oak 


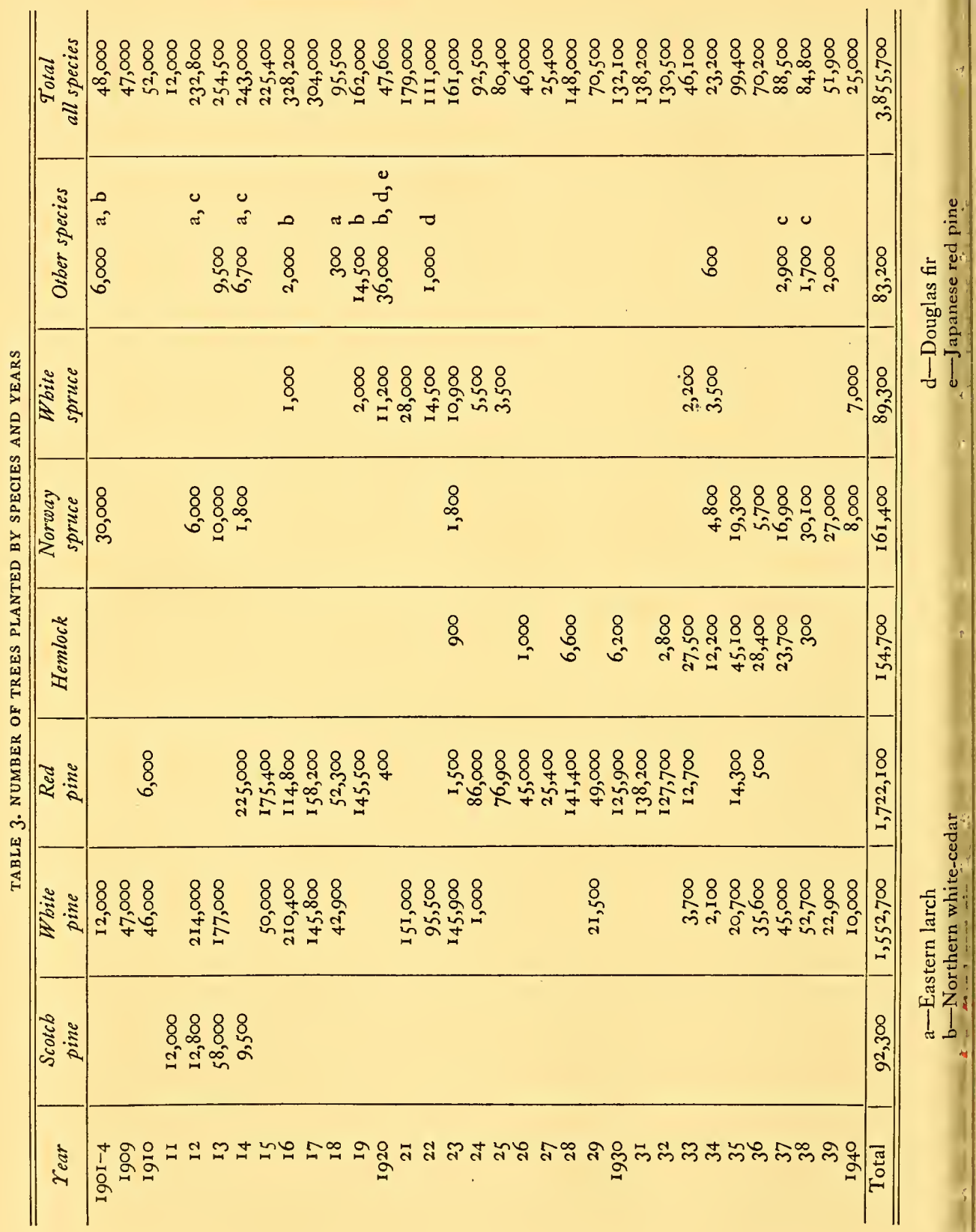


instead of the conifers. The Eli Whitney forest, however, contains about 16,000 acres of natural hardwood forest and relatively few areas of conifer forest. Hence, the purpose in planting was to establish conifer forest on the existing open lands, thereby increasing the proportion of conifer to hardwood forest.

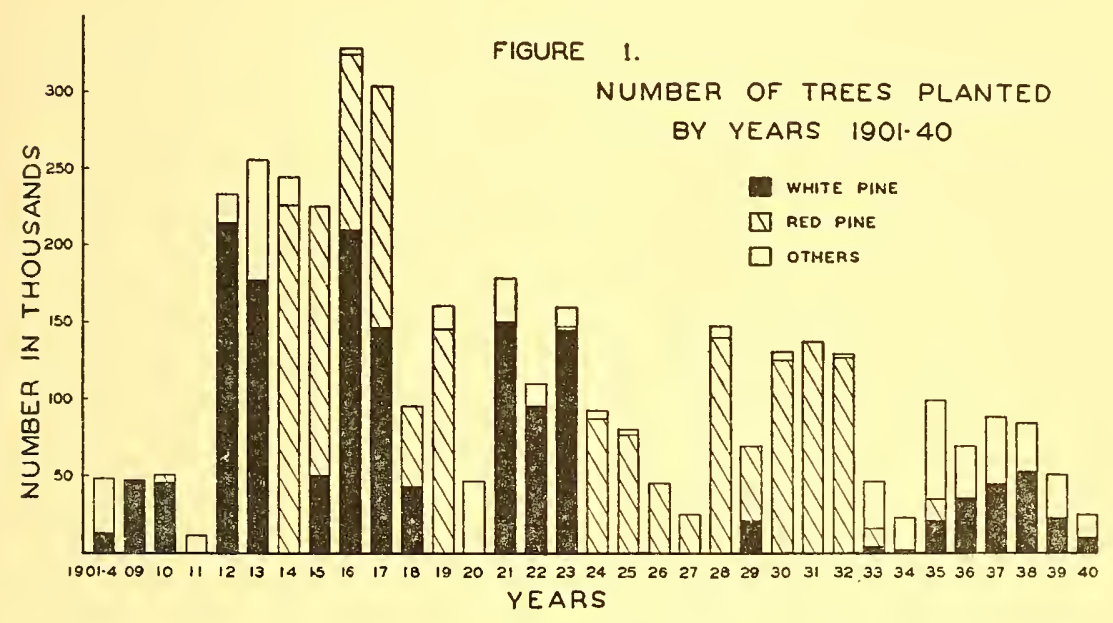

\section{Seed Source}

In the light of present-day emphasis upon accurately known and correctly chosen seed sources the early efforts to obtain seed were not highly scientific. Nevertheless, over the forty-year period most of the seed of the two principal species planted, namely, white and red pines, was secured from regions sufficiently like southern Connecticut in climate to ensure a race suited to the region. More seed of these species has come from the territory in northern New York, lying between Lake Champlain and the Adirondacks, than from any other locality. In a few cases red pine and less frequently white pine seed was secured from the Lake States region. Once or twice white pine seed was brought in from Germany, exact source unknown, and for two years (Igog and I9I0) white pine transplants were purchased from a German nursery. Incidentally, the stock so secured developed in to one of the best plantations in the forest.

Many of the white pine plantations are now 25 to 30 years of age and 
are beginning to bear enough cones to be worth collecting. In the future locally collected seed will be the main source of supply for nursery stock of this species.

Norway spruce seed has been secured from German or Swedish sources. A few of the planted stands are approaching seed-bearing age and as soon as possible will be used as seed sources for future Norway spruce planting. White spruce seed has been obtained either from northern New England or eastern Canada. Only in the case of Scotch pine have bad conditions traceable to wrong seed source developed in the plantations. Undoubtedly the few Scotch pine plantations established on the forest are composed of trees which belong to inferior races or else are unsuited to the climate (see Plate I2).

In conclusion, the policy of using seed from thrifty trees of high quality growing in or near the Eli Whitney forest is accepted as advisable and will be applied as rapidly as possible. The fact that this policy has not been pursued strictly in the past, owing to lack of an adequate local seed supply, has not had the evil effects which in theory might have accrued. That bad results from wrong seed source have been so inconsequential may be attributed; first, to using a native species (white pine) and seed from similar climatic regions for a large share of the planting, second, to using other American species not native to southern Connecticut but almost so (red pine and white spruce), while finally, Norway spruce, the chief foreign species used, had been already proven through landscape planting to be suited to the climate.

\section{Pure versus Mixed Plantations}

Most of the planting in the Eli Whitney forest has been of pines in pure stands. Because of the diversity of site conditions, land use, and vegetation cover, the average plantation is of relatively small area. A single pure plantation, not interspersed with other species, as large as 40 acres is a rarity (in fact only two of approximately that area have been established), one of 20 acres is unusual, and the average will fall below Io acres in size. The natural forest adjoining and interspersed within the plantations, along old fence lines and on small never-cleared, more shallow-soiled, or stonier areas than those cleared for agriculture, is of hardwood composition, forming a decided contrast to the conifer plantations.

Pure stands theoretically are considered less satisfactory than mixed 
stands. Greater safety from injurious agencies is the chief argument for the mixed stand, since failure of one species will not result in loss of the whole crop as in the case of the pure stand. Furthermore, it is sometimes argued that there is less chance for a serious attack by a plant pest upon a single species in a mixed than in a pure stand because smaller quantities of the same food are available in the former than in the latter kind of plantation. This argument has its practical limitations since mixed plantations are customarily made to contain only a few species and will ordinarily afford sufficient food of a given kind of tree to encourage strong development of plant pests.

In spite of these arguments the expense of planting leads the forester in many instances to plant the one species which is best adapted to the site and is likely to give a return justifying the costs of establishment. As planting has been conceived in relation to long-time policy in the Eli Whitney forest, the forest type established by planting is intended for one rotation only. The forest which follows may or may not be the same as the planted stands. This point will be brought out in some detail later on in discussing the natural cycle of development in the planted forest. Recognition of this viewpoint goes far toward taking the alleged curse off the pure plantation. Experience to date in the Eli Whitney forest indicates that adaptability to the site coupled with proper treatment is of greater importance to the success of a plantation than the question of whether the stand is pure or mixed.

Because of the danger from the white pine blister rust, planting of white and red pines in an intimate mixture was tried in 1917 and 19 I8. Single rows of each species were alternated with the idea that if the white pine was killed by the rust, red pine would remain to furnish a full stand. This proved to be a poor arrangement for the reason that the red pine outgrew the white pine in most instances. Furthermore, it finally developed that there was more danger of the red pine being ruined by the European pine shoot moth than there was of the white pine succumbing to blister rust, because of the relatively sure and cheap control possible for this disease. Mixing the red and white pine in alternate rows furnished an illustration of an unwise arrangement, because of the difference in early height growth between the two species.

The making of relatively small pure plantations has continued and is still considered to be a satisfactory method for this region.

As an experiment to determine the minimum space which an individual species requires, in order to establish itself surely in a dominant position 
in stands of merchantable age, several areas have been planted with mixtures of two to four species arranged in the form of small squares of one species adjoined by similar-sized squares of other species. Squares ranging in size from those containing 9 to 36 trees have been used, with the individual trees spaced 6 by 6 feet apart. Figure 5 illustrates the arrangement in a plantation containing four species each planted in units of 9 trees. The 9-tree square is the smallest which might be expected to guarantee that at least one tree, the individual in the center, will be protected against encroachment by adjoining species. The 36 -tree unit occupying a 36 by 36 foot square certainly should ensure the survival of several trees from each unit. Units containing a smaller number of trees may prove equally satisfactory. Whether mixed plantations of this character will be any more safe from insect and fungus injury than small pure stands is an open question. Abundant food, sufficient for a given insect to develop into a serious pest, might be provided even if a fourspecies mixture were used.

It is quite possible to make mixed plantations of this small groupwise type without appreciably increasing per acre costs, provided too great stress is not laid upon obtaining exactly the same number of trees in each group. In the mixed plantations, which were established in 1934 and subsequent years, Norway spruce, white pine, and red oak have been the principal species used (see Plate I3). It is believed that yellowpoplar should be tried with these two conifers. Ten per cent of the plantation area put into hardwoods is considered ample for southern Connecticut, because of the scarcity of softwood stands and the abundance of hardwoods. Information on the relationships developed between the species planted in these mixed stands will eventually furnish guidance for establishing good mixtures, if such stands are desired.

It is of interest to note that at the present time, after only nine years' growth in the field, substantial differences are to be observed in the development of the species employed for the groupwise mixtures established in 1934. Measurements obtained at the end of the 1942 growing season are presented in Table 4, and shown graphically in Figure 4. So far white pine has shown the most rapid growth and red oak the slowest. Development of spruce and hemlock is practically the same and falls about midway between the extremes set by the other two species. The differences in total height, crown length, and crown width shown in Table 4 give little basis for predicting subsequent development of the four species, but they do indicate marked variations in the initial growth 
rate and crown development. The relatively slow development shown by red oak is owing to injuries caused by mice and rabbits during the first few years after the plantation was established.

TABLE 4. DEVELOPMENT OF FOUR SPECIES IN A MIXED PLANTATION AFTER NINE YEARS' GROWTH IN THE FIELD

\begin{tabular}{l|c|c|c}
\hline \hline Species & Total beigbt, feet & Crown length, feet & Crown width, feet \\
\hline Spruce & $9.2 \pm .28$ & $8.7 \pm .28$ & $4.7 \pm .13$ \\
Red oak & $6.8 \pm .60$ & $4.4 \pm .53$ & $3.2 \pm .36$ \\
Hemlock & $9.1 \pm .54$ & $8.8 \pm .48$ & $4.5 \pm .27$ \\
White pine & $11.7 \pm .43$ & $11.2 \pm .42$ & $6.6 \pm .22$ \\
\hline
\end{tabular}

\section{Growing the Nursery Stock}

As earlier stated, nearly all stock planted in the Eli Whitney forest has been grown locally. The conifers have been sown broadcast and kept in the seedbeds for two years with few exceptions. Transplanted when two years old, the pines have been grown for one year in transplant beds and the spruces either one or two years, though preferably the latter. Red oak, the only hardwood which has been grown in any quantity, is sown in drills and taken from the nursery when one year old. The oak acorns are gathered in the fall and stratified over winter in layers of sand several feet below the ground level. Thus the stock commonly sent out from the nursery for planting in the field is of the following classes:

$\begin{array}{lll}\text { White pine } & (2-1) & \text { 3-year-old transplants } \\ \text { Red pine } & (2-1) & \text { 3-year-old transplants } \\ \text { Norway spruce } & (2-2) & \text { 4-year-old transplants } \\ \text { White spruce } & (2-2) & \text { 4-year-old transplants } \\ \text { Red oak } & (1-0) & \text { I-year-old seedlings }\end{array}$

The planting sites are characterized by heavy grass sod, which offers severe competition to the planted trees, particularly in the upper soil layer (see Plate I). For this reason strong stock is needed. Two-year-old seedlings of white and red pine are less satisfactory than 3 -year-old transplants. Sufficiently better results have been obtained with 4-yearold Norway and white spruce transplants to justify leaving the spruces an extra year in the transplant beds.

Red oak plantations have been established both with I-year-old seedling stock and by direct seeding with acorns (see Plate ${ }_{4} 4$ ). On the whole, 
use of the seedling stock has proved more satisfactory than field planting of the acorns, although success in establishing plantations has been secured by the latter method.

On properties where the planting program requires only a small quantity of trees it often will be the best policy to buy rather than to grow the desired nursery stock.

\section{Planting Methods}

The thick grass sod, already mentioned as typical of the planting sites, and prevalence of loose rock in the soil prevents successful use of a compression method of planting. ${ }^{2}$ Removal of the grass sod for a small distance around the planted tree is needed to reduce competition in the first weeks after planting. This is accomplished by scalping off the sod with a grubhoe over a 12- to 15-inch square. In the center of the scalped spot, a hole is dug deep enough to accommodate the tree roots without undue doubling up of the root system. Either the side hole or center hole method of setting the tree may be used, although the former results in more efficient work with the class of labor employed. In a few cases plowing of furrows to turn back the sod has been used, and under the proper conditions may reduce the expense or increase the survival and consequently be worth while.

In the side hole method the tree with roots spread out is held against a vertical side of the hole, then soil free of litter is packed against the roots and the hole filled with earth. In the center hole method the tree is held at the correct height over the center of the hole and soil is packed over and around the roots. There is a tendency in using this method to compact the root system vertically and to get the tree planted too low down in the hole.

\section{SPACING}

In most of the plantations the trees have been set out 6 by 6 feet apart. This spacing provides room for I,210 trees per acre. Application of the 6 by 6 foot spacing, under the conditions usually encountered in the

2. Compression methods of planting are those in which special tools (often known as planting bars) similar in type to the ordinary spade are forced in to the soil, opening a slit into which the tree is inserted. It is a cheaper, less careful method of planting than the hole method. 
field, has resulted in setting out trees at the rate of from 1,000 to 1,250 trees per acre with the tendency toward using less than I,200 trees. The foremen have been urged not to set the trees closer than 6 by 6 feet apart and in some cases have come nearer to a 6.5-foot spacing, or I,000 trees per acre. Where patches of dense brush or tree reproduction occur in otherwise open fields such areas are not planted. Here the actual number of trees set per acre may fall considerably below I,200, depending on the percentage of the area occupied by the non-planted patches. Initial spacing in plantations should be determined by the average survival percentage in relation to the number of trees desired in young established plantations. The trees must be set close enough together to provide for a well-stocked stand of young trees after the early losses from climatic factors and other causes, which ordinarily occur in the first five years after planting, have taken their toll. On the other hand, the number surviving must not be so great as to result in severe early competition between individual trees leading to stagnation of growth.

For white pine ${ }^{3}$ and the spruces a 6 -foot spacing has given a satisfactory survival, neither too dense nor too open. Five years after the planting of $\mathrm{I}, 200$ trees per acre there usually will be 800 to 900 living trees per acre in the case of white pine, 900 to I,I00 in the case of Norway spruce, and $I, 000$ to over $I, I 00$ in the case of red pine. Experience has shown that 6 -foot spacing is too close for red pine under the economic conditions prevailing at present. The survival frequently exceeds 90 per cent of the original planting, and results in stands so dense that diameter growth of this relatively light-demanding tree is reduced too radically and unremunerative early thinnings may be needed to avoid stagnation. Hence a change in spacing to 8 by 8 feet has been used since 1930 for red pine with excellent results (see Plate Io).

Replanting blanks caused by death of trees in the first few years following establishment has proved to be unnecessary in most plantations. If the mortality is scattered through the plantation with reasonable regularity losses up to 50 per cent of the initial stocking in 6-foot spacings and up to 25 per cent in 8 -foot spacings are accepted without replanting.

3. In localities where damage from the white pine weevil is more difficult and expensive to control than is the case in southern Connecticut a 5 by 5 foot spacing, requiring approximately 1,740 trees per acre, may prove advisable in plantations of white pine. Such spacing provides for relatively early closure. The consequent competition between adjoining individuals forces the weeviled trees to grow in upright rather than bushy form, thereby minimizing the damage from the weevil. Use of such a close spacing is likely to require an early thinning before the value of the material to be removed is great enough to pay expenses of the operation. 
Since exceptional droughts or other destructive agencies occasionally cause concentrated losses, killing groups of trees, some replanting has been essential. Plantations under normal conditions are looked over 3 to 5 years after the original date of establishment and any refilling required is attended to at that time. The object in refilling plantations is not to set a new tree on each spot where a previously planted tree has died but, instead, only to plant openings where several trees have died. Any blank less than that caused by the death of a 9-tree group is scarcely worth filling, provided the portion of the stand surrounding the blank is reasonably solid.

\section{Planting Site in Relation to Species}

The soils of the Eli Whitney forest are with minor exceptions relatively heavy-textured as compared with the water-laid sands and gravels found more abundantly elsewhere in New England than in southern Connecticut.

As previously stated, the open areas available for forest planting include average to better sites in the forest. All of the soils are fertile enough for excellent growth of the conifers which have formed the bulk of the planting. On the basis of moisture relations certain broad classes may be recognized among the planting sites. Lands somewhat slowly drained (really wet lands are excluded from the planting program) should be planted to hardwoods, particularly red oak and yellowpoplar. Possibly white spruce will succeed on these sites although this has not been established by local experience as yet (see Plate 7). White pine may be planted on all well-drained sites except very shallow soils. These latter should be excluded from the planting program and allowed to reforest naturally with hardwoods and hemlock. The better half of the welldrained sites can be reforested with Norway and white spruce as well as with white pine.

\section{NATURAL CYCLE OF DEVELOPMENT}

\section{Creation of a Forest Canopy}

NOW that the details which relate to plantation establishment have 1 been reviewed the natural cycle of development which has been (and still is) in operation since establishment can be discussed. One of 
the important points in plantation development concerns the creation of a complete forest cover on the site which at the time of planting was bare of trees.

The old fields, constituting the bulk of the areas planted, usually are stocked at the time of planting with luxuriant vegetation consisting of herbaceous plants, often with scattered shrubs and occasional tree seedlings (see Plate I). In Table 5 are indicated the herbaceous plants having the highest frequency and cover density on the average old field planting sites. ${ }^{4}$ It is evident that a large proportion of the vegetation consists of grasses. Variations in species composition and density of cover occur with differences in soil conditions and time since cultivation. As a rule the number of species and the density of cover is greatest on the best soils and also increases with the length of time since cultivation.

The shrubs most frequently encountered an old field planting sites are poison ivy (Rbus radicans L.), dwarf sumac ( $R$. copallina L.), smooth sumac ( $R$. glabra L.), staghorn sumac ( $R$. typbina L.), bayberry (Myrica carolinensis Mill.), sweet fern ( $M$. asplenifolia L.), hardhack (Spiraea tomentosa L.), and common juniper (Funiperus communis L. var. depressa Pursh.). Tree seedlings which occasionally occur are usually those of trees having seeds which are disseminated either by wind or birds, for example, eastern red cedar, gray birch, flowering dogwood, sassafras, white ash, and red maple.

The strong competition afforded planted trees by the natural vegetation is an important factor in determining survival of the plantation and rate of growth during its early years. Ultimately the herbaceous vegetation is outgrown by the planted trees and, as these increase in size, is overtopped and largely eliminated by the shade and competition of the new forest. Once the crowns of adjoining planted trees touch each other, thus establishing a closed forest canopy, the vegetation characteristic of old fields quickly disappears (see Plate 2).

The number of years after the planting date required for this closed forest canopy to develop depends upon the species planted, the productive capacity of the site, the original spacing at which the trees were planted, and the number which survived after planting. In the Eli Whitney forest the spacing has been fairly constant at 6 by 6 feet with the exception of red pine planted since 1930. Three species, white pine, red pine, and Norway spruce have been commonly used. Since the varia-

4. Data in Table 5 were secured by Arnold D. Rhodes and are filed in the Yale School of Forestry. 
TABLE 5. LIST OF HERBACEOUS PLANTS HAVING A HIGH FREQUENCY AND COVER DENSITY IN OLD FIELDS (ALL SPECIES LISTED HAVE A FREQUENCY OF SO PER CENT, OR MORE; THOSE INDICATED WITH AN ASTERISK HAVE A COVER DENSITY OF IO PER CENT, OR MORE)

\begin{tabular}{ll}
\hline \multicolumn{1}{c}{ Scientific name } & \multicolumn{1}{c}{ Common name } \\
Achillea millefolium L. & Common yarrow \\
Agrostis alba L. & White bent grass* \\
Ambrosia artemisiifolia L. & Ragweed \\
Andropogon scoparius Michx. & Broom beard grass* \\
A. virginicus L. & Beard grass \\
Anthoxanthum odoratum L. & Sweet vernal grass* \\
Chrysanthemum leucanthemum L. & Ox-eye daisy \\
Danthonia spicata (L.) Beauv. & Wild oat grass* \\
Daucus carota L. & Wild carrot \\
Erigeron ramosus (Walt.) BSP. & Daisy fleabane \\
Hieracium pratense Tausch. & King devil* \\
Juncus tenuis Willd. & Slender rush \\
Oxalis stricta L. & Yellow wood sorrel \\
Panicum tennesseense Ashe. & \\
Paspalum muhlenbergii Nash. & \\
Phleum pratense L. & Timothy \\
Plantago lanceolata L. & English plantain \\
Poa compressa L. & Creeping spear grass* \\
P. pratensis L. & June grass \\
Potentilla canadensis L. & Cinquefoil* \\
Prunella vulgaris L. & Heal-all \\
Rubus villosus Ait. & Dew-berry* \\
Rumex acetosella L. & Sheep sorrel \\
Solidago graminifolia (L.) Salisb. var. Nuttallii (Greene) & \\
Fernald & Golden-rod \\
S. juncea Ait. & Golden-rod \\
S. nemoralis Ait. & Oldfield golden-rod \\
S. rugosa Mill. & Wrinkled golden-rod \\
Trifolium agrarium L. & Yellow clover \\
T. pratense L. & Red clover \\
T. repens L. & White clover \\
\hline \hline
\end{tabular}

tions in site have not been great, characteristics of the species as to growth rate, spreading habit, and ability to survive become the determining factors here in fixing the time required for creation of a forest canopy.

Red pine plantations, characterized by a survival of 90 per cent or better, when spaced 6 by 6 feet may form forest canopies within 7 years after planting and on the average do so within I I years (see Plate 8). Where the preferable spacing of 8 by 8 feet is used, closure does not take place until 12 to 15 years after red pine is planted (see Plate I I).

White pine, with an early survival averaging about 70 per cent, does 
not form a forest canopy on the average until the fourteenth year following establishment. In rare instances a canopy may be formed by the seventh or eighth year. The lower survival of white as contrasted to red pine more than offsets the somewhat more rapid spread of the side branches which characterizes white pine in pure plantations and results in tardier development of a forest canopy in pure plantations of this species. Figure 2 shows the progress of closings in pure white, pure red, and mixed white and red pine plantations based on measurements taken on 37 permanent sample plots in the Eli Whitney forest.

Norway spruce, although it has better early survival than white pine, grows more slowly for the first decade, both in height and horizontal spread, than either this or the red pine. These characteristics result in a period of at least 10 and on the average over i 5 years between date of planting and creation of a forest canopy.

\section{Formation of a Forest Floor}

Under the term forest floor is meant the layer of dead leaves, needles, and twigs which mantles the mineral soil in the forest. It stands in definite contrast to the dense, living herbaceous cover which clothes the soil on the old field planting sites. From the standpoint of water conservation, areas with a good forest floor are rightly considered to have advantages over old fields covered with herbaceous vegetation.

Formation of a forest floor is accomplished by the accumulation on the ground of dead leaves and twigs as they fall from the standing trees. The covering and smothering action of this material upon the herbaceous vegetation together with the shading effect of the living foliage of the planted trees and the underground competition of the tree roots, all combined, results in the gradual death of the original old field vegetation and the establishment in its place of an excellent forest floor (see Plate 8 ). The process is gradual and begins directly under each of the small planted trees. As these trees increase in size and in density of foliage an ever-widening circle of forest floor is formed under each tree. These individual zones finally merge as the tree crowns meet, thus forming a continuous forest floor under the stand.

5. Taken from an unpublished manuscript by Arnold D. Rhodes in files of the Yale School of Forestry. 
FIGURE 2.

\section{PROGRESS OF CLOSING OF PINE PLANTATIONS}

- PURE WHITE PINE $\leadsto$ PURE RED PINE $\rightarrow$ WHITE AND RED MIXED

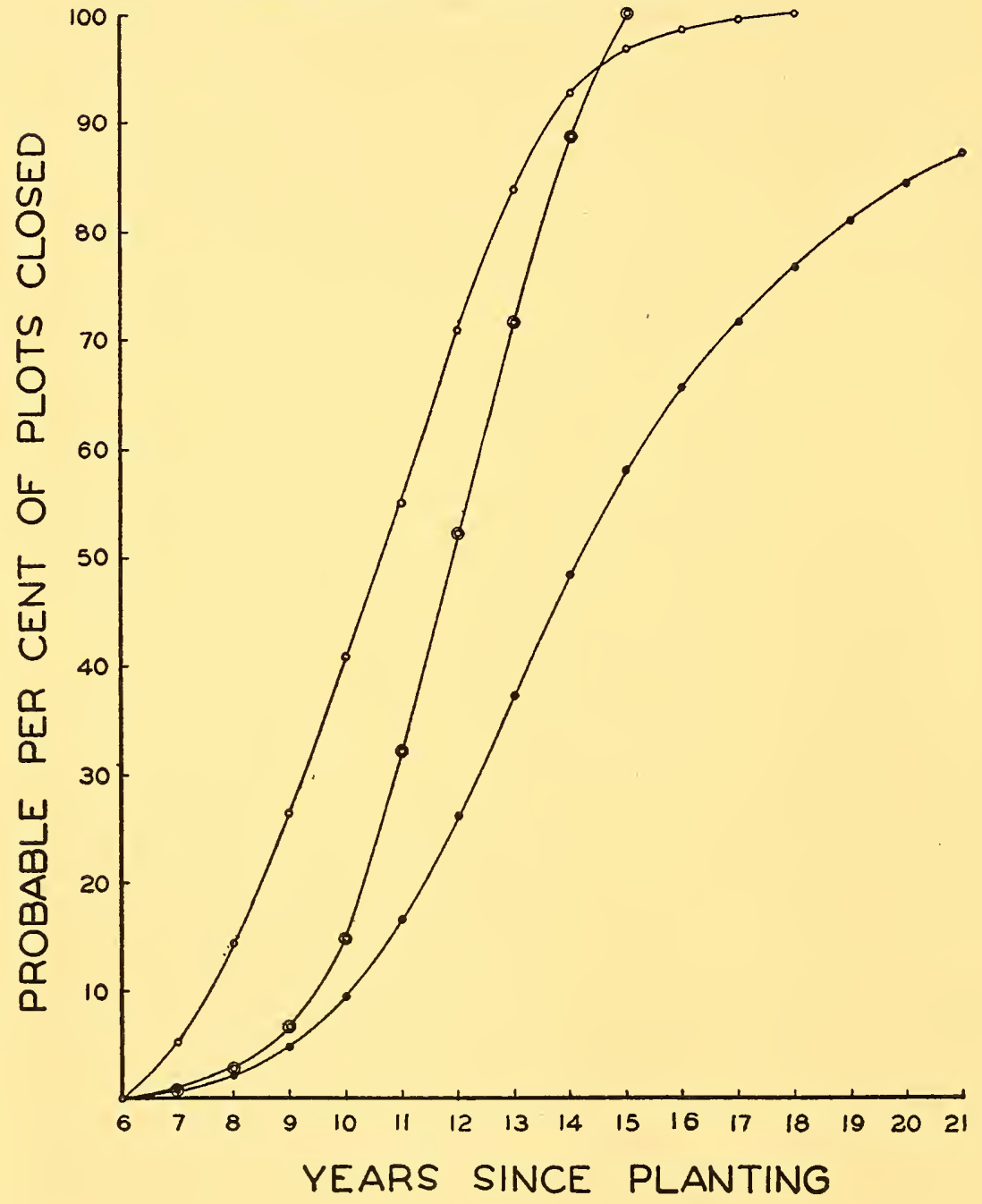




\section{Disappearance of the Herbaceous Vegetation}

The closing of the forest canopy and development of a forest floor results in the virtually complete disappearance of the plants which were so vigorous and abundant in the open fields. Soon after closing the forest becomes so dense and light-excluding as to render the area practically barren of herbaceous plants. Admittedly this is only a temporary condition. Gradually there will enter herbaceous species better suited to conditions in the forest than were those plants characteristic of open fields. The latter as a group definitely disappear and do not return while the area remains forested.

\section{Dying of the Lower Branches}

With the closure of the canopy the forest gains complete domination over other forms of vegetation on the area (see Plate 3 ). There now begins intense competition between the individual trees in the forest which continues throughout life. Control and intelligent direction of this competitive struggle for existence is one of the principal means which the forester uses in producing crops of good timber. Hence it will be of value to inquire further in to the details of the competition. Its first manifestation is the dying of the lower limbs on trees with branches touching or interlocked with those of neighboring trees. This process is very evident as soon as the forest canopy has formed and may even occur to a limited extent on trees not yet touched by their neighbors in cases where the lower branches are outgrown and thickly covered by branches higher up the stem.

Once closure of the forest canopy is attained dying of lower limbs is hastened and progresses up the stem as fast as contact between adjoining trees is made (see Plate 8). Limbs below the highest point of contact are shaded and soon die (see Figure 3). Thus the live crown soon becomes restricted to the upper part of the tree and in exceptionally dense stands may ultimately become reduced to a small tuft of living foliage. Since growth of the trees is dependent upon and roughly proportional to the foliage area of the live crown it is essential that the latter should not undergo too great a reduction. How great a reduction can be allowed without serious injury is discussed in the next section. 
FIGURE 3.

ARRANGEMENT OF BRANCHES ON A WHITE PINE TREE IN RELATION TO THOSE ON TWO ADJOINING TREES

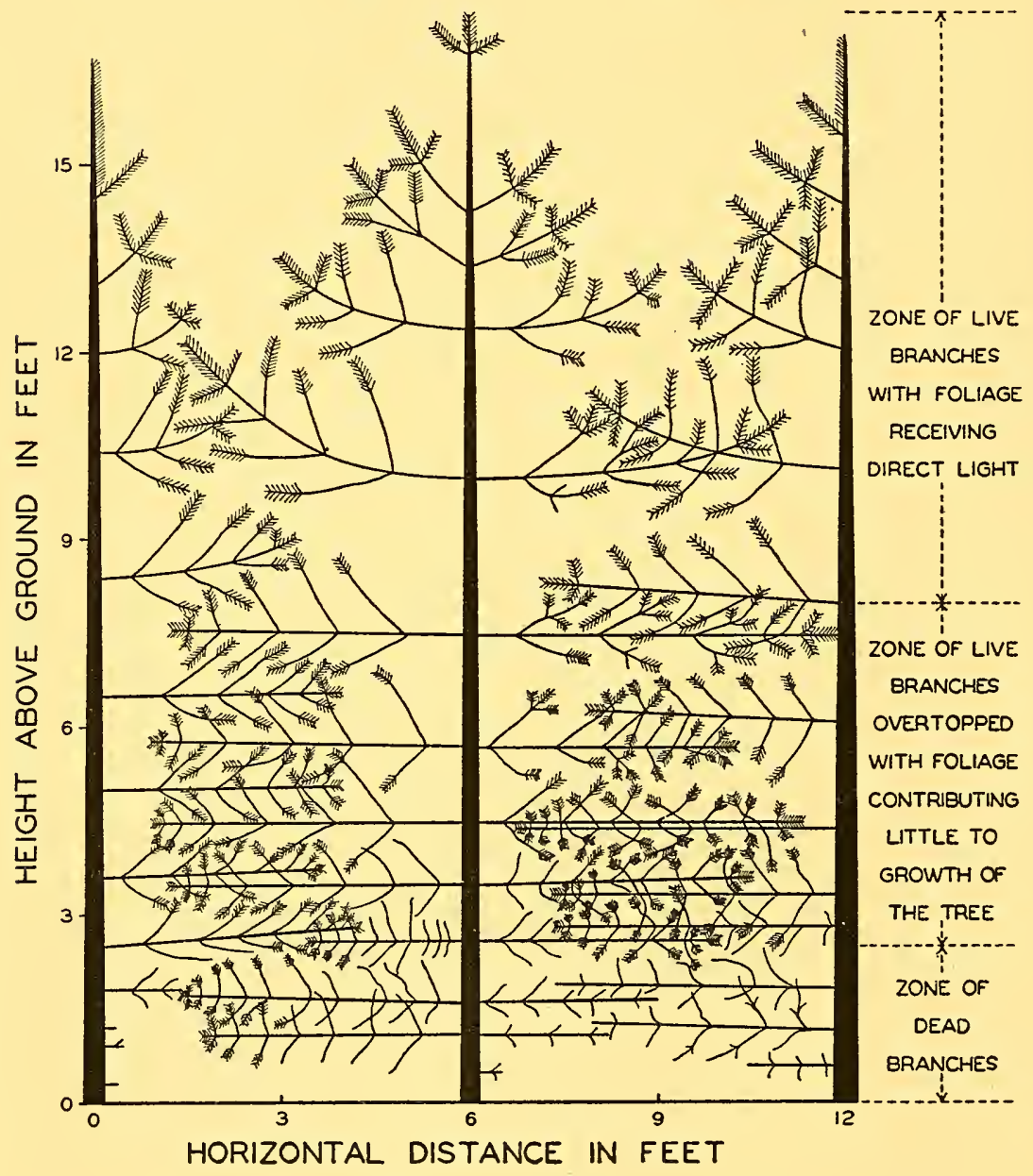


Figure 3 has been drawn to scale showing the competition between a white pine tree and two of its neighbors. The trees were planted 6 by 6 feet apart and had grown in the plantation for 15 years when measured. The diagram recognizes three zones based on the condition of the branches and the photosynthetic activity of the foliage. In the lower zone the branches are practically dead and devoid of foliage; in the middle one the foliage overtopped by the live branches above is sparse and unhealthy and can contribute little toward growth. In the upper zone most of the branches are free; the foliage receives an abundance of direct light and is primarily responsible for the growth of the tree.

It is interesting to note in these plantations how widely the branches of white pine overlap and how deeply they interlace. In pruning a stand in this condition all branches in the two lower zones can be removed without adversely affecting the growth. 


\section{Live-Crown Ratio}

The proportion of the total height of the tree which is occupied by the live crown is known as the "live-crown-total-height ratio" and usually is expressed as a percentage. It is a valuable index to the form and vigor of the individual tree and should be of practical importance in the details of management, particularly in determining the times when thinnings should be made. The term is often abbreviated to "live-crown ratio" and will be so used throughout this publication.

A well-formed vigorous tree should in general have a live crown that extends approximately one-third of the way from the top of the tree down to the ground. The desirable size of this ratio is not always the same but may vary with species of tree, age, and particularly with the form of product which is being grown. Trees with a large live-crown ratio are stocky in form, while trees with a small live-crown ratio are much more slender and consequently weaker in resistance to external forces. In young conifer plantations, such as those here discussed, this ratio is of great importance in determining the time when the first and subsequent thinnings should be made. There is danger in rapidly growing, densely stocked, young plantations that death of the lower limbs will progress upward so fast as to endanger the vigor of the trees. By observing the live-crown ratio and by thinning before this index drops to a dangerously low point the vigor of the stand can be maintained.

The possibility of reducing the live crown to a dangerously low point is greatest with species like red pine, which are relatively light-demanding and do not possess the characteristic of a rapid expression of dominance (for further explanation see page 30 ). Such species when grown in plantations are more likely to develop a low live-crown ratio than are stands of white pine or Norway spruce which possess ability to express dominance rapidly. As already stated when discussing spacing, the number of red pine trees planted per acre was changed from approximately I, 200 to less than 700 because with the good survival of this species the larger number was likely to result in too severe crowding at an early age, reducing diameter growth too radically and ultimately bringing the live-crown ratio down too low.

Measurements ${ }^{6}$ and observations over a series of years lead to the

6. Data relating to live-crown ratios were secured by Gordon Chapman and Arnold Rhodes and are found in unpublished manuscripts in Yale School of Forestry files. 
following conclusions as regards live-crown ratios for red pine, white pine, and Norway spruce plantations. A live-crown ratio of at least 35 per cent is desirable for red and white pines and Norway spruce. This figure is intended to apply to all the trees which will remain in the stand to form the final crop. It does not apply to trees which will be removed or overcome by competition as the crop is growing.

The natural dying of lower limbs in white pine and Norway spruce plantations originally spaced 6 by 6 feet progresses at such a rate that the live crown remains safely at one-third or more of the total height for at least the first 25 to 30 years without any treatment by the forester. In Norway spruce stands of this age the live-crown ratio is likely to be at least 45 per cent.

Even in red pine stands, originally spaced 6 by 6 feet, in many cases the live-crown ratio is maintained at 35 per cent or more for the first 25 years. This may not be true on some of the poorer sites. It is possible that on all sites live-crown ratio for red pine may drop below 35 per cent by the time stands reach 30 years of age.

Data relative to live-crown ratios in mixed stands of red and white pine (alternate row mixtures) which were established in I9I 7 are presented in Table 6. The data are based on a total of 200 trees of each species selected at random. Two features are worthy of note: (I) in both species the livecrown ratio usually exceeds 35 per cent, and (2) red pine has a higher ratio than white pine. The latter feature is explained by the fact that in alternate row mixtures red pine generally outgrows white pine and soon restricts growth of the latter species.

Measurements of live-crown ratios in pure stands of red and white pine present a different picture. On the basis of random samples from

TABLE 6. LIVE-CROWN RATIOS IN ALTERNATE ROW MIXTURES OF RED AND WHITE PINE STANDS 26 YEARS OLD

\begin{tabular}{l|l|l}
\hline \multirow{2}{*}{ Plot } & \multicolumn{2}{|c}{ Live-Crown Ratio } \\
\cline { 2 - 3 } & Red pine & Wbite pine \\
\hline 33 & $44 \pm \mathrm{I} .6$ & $40 \pm 2.2$ \\
37 & $43 \pm \mathrm{I} . \mathrm{I}$ & $4 \mathrm{I} \pm 2 . \mathrm{I}$ \\
47 & $48 \pm \mathrm{I} .7$ & $38 \pm 2.3$ \\
48 & $49 \pm \mathrm{I} .6$ & $36 \pm \mathrm{I} .2$ \\
50 & $40 \pm \mathrm{I} .2$ & $27 \pm \mathrm{I} .4$ \\
5I & $40 \pm \mathrm{I} .4$ & $36 \pm \mathrm{I} .9$ \\
5IC & $42 \pm \mathrm{I} .6$ & $39 \pm 1.8$ \\
6IC & $28 \pm \mathrm{I} .4$ & $29 \pm \mathrm{I} .7$ \\
\hline
\end{tabular}


8 pure stands of each species the average live-crown ratio in red pine was found to be $38 \pm 0.9$ and in white pine $42 \pm 1.5$. The stands investigated were 26 to 27 years old. As mentioned earlier, white pine in pure stands shows much better expression of dominance than red pine. This accounts for the higher live-crown ratio in the former species.

\section{Crown Spread, Total Height, and Diameter of White and Red Pine in Mixed and Pure Stands}

Development of white and red pine trees in mixed plantations having alternate rows of the two species has been investigated in 8 different stands. In each stand a random sample of 25 trees of each species was measured with the results shown in Table 7. Owing to the difference in rate of growth of the two species when occurring in mixture there is a definite tendency toward asymmetry of crowns. This is indicated by the fact that white pine crown diameters measured along the white pine rows are generally greater than the diameters measured across the rows, and that red pine crown diameters measured across the rows are greater than the diameters measured along the red pine rows. Vertical projections of the crowns of both species tend toward a broadly ellipsoidal form; in white pine the long axis of the crown projection is parallel to the row but in red pine it is at right angles to the row. Expansion of red pine crowns in mixed stands is more rapid than in white pine so adjacent crowns of the former species meet, and enter into competition, earlier than do adjacent crowns of white pine. Branches of the red pine continue to develop in to the remaining free space on the sides adjacent to white pine and soon restrict crown spread in the latter species by crowding and overtopping. Mean crown diameters of white pine are consistently less than in red pine.

As indicated in Table 7 white pine averages a few feet less in total height than does red pine. In part the lower height of the white pine results from weevil damage. White pine diameters are also a little lower than those of red pine but the difference is usually slight.

Measurements were also taken on 200 trees in 8 pure plantations of red pine and on 200 trees in 8 pure plantations of white pine to obtain a comparison of the development of the two species. The stands investigated were 26 to 27 years old. In the pure stands, just as in the mixed plantations discussed earlier, white pine averages a little lower than red pine in total height, the values being $38 \pm 0.7$ and $40 \pm 0.6$ feet, respec- 


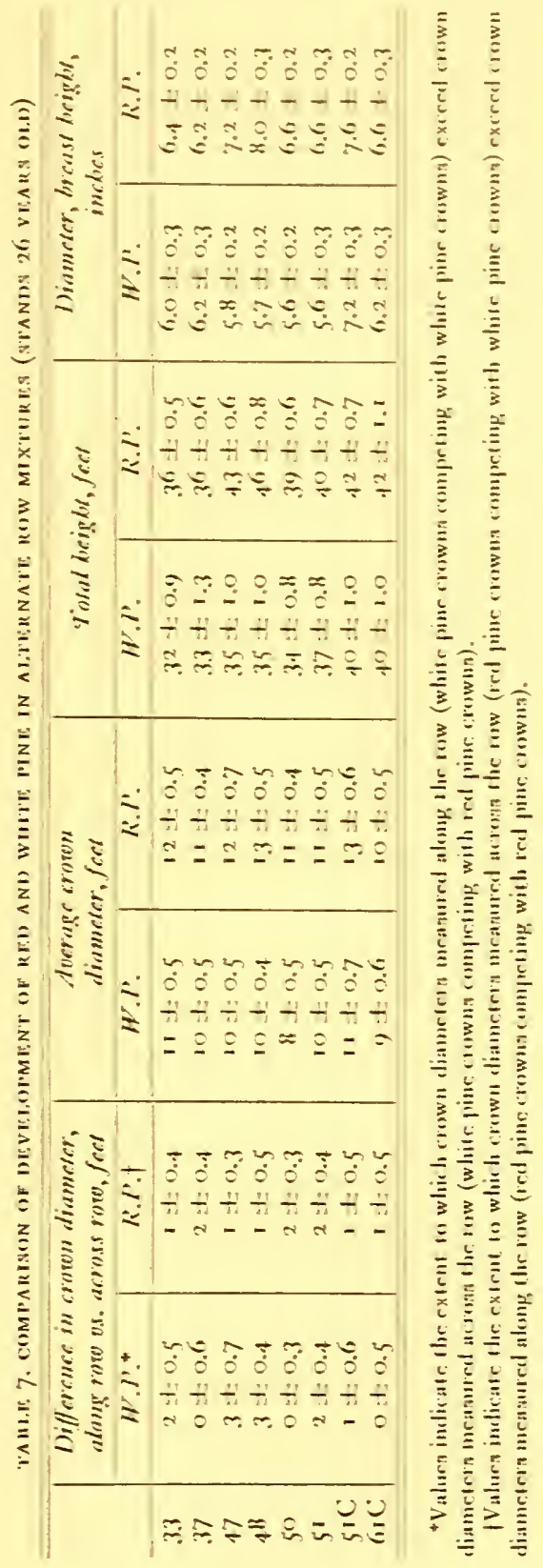


tively. On the other hand, white pine in pure stands has a somewhat higher average stem diameter (white pine 7.I \pm 0.1 and red pine $6.2 \pm 0.1$, inches) and a higher average crown diameter (white pine I I \pm 0.3 and red pine $9 \pm 0 . \mathrm{I}$, feet) than red pine. This may be ex-

FIGURE 4.

PROFILE THROUGH A MIXED PLANTATION SHOWING FOR 4 SPECIES THE TOTAL HEIGHT,

LENGTH OF LIVE CROWN, AND CROWN WIDTH 8 YEARS AFTER PLANTING

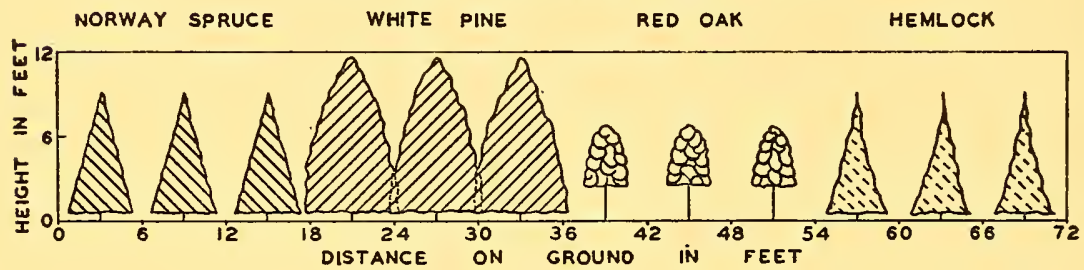

FIGURE 5.

VIEW SHOWING ARRANGEMENT USED IN MIXED PLANTATION CONTAINING 4 SPECIES, EACH PLANTED IN PURE GROUPS OF 9 TREES

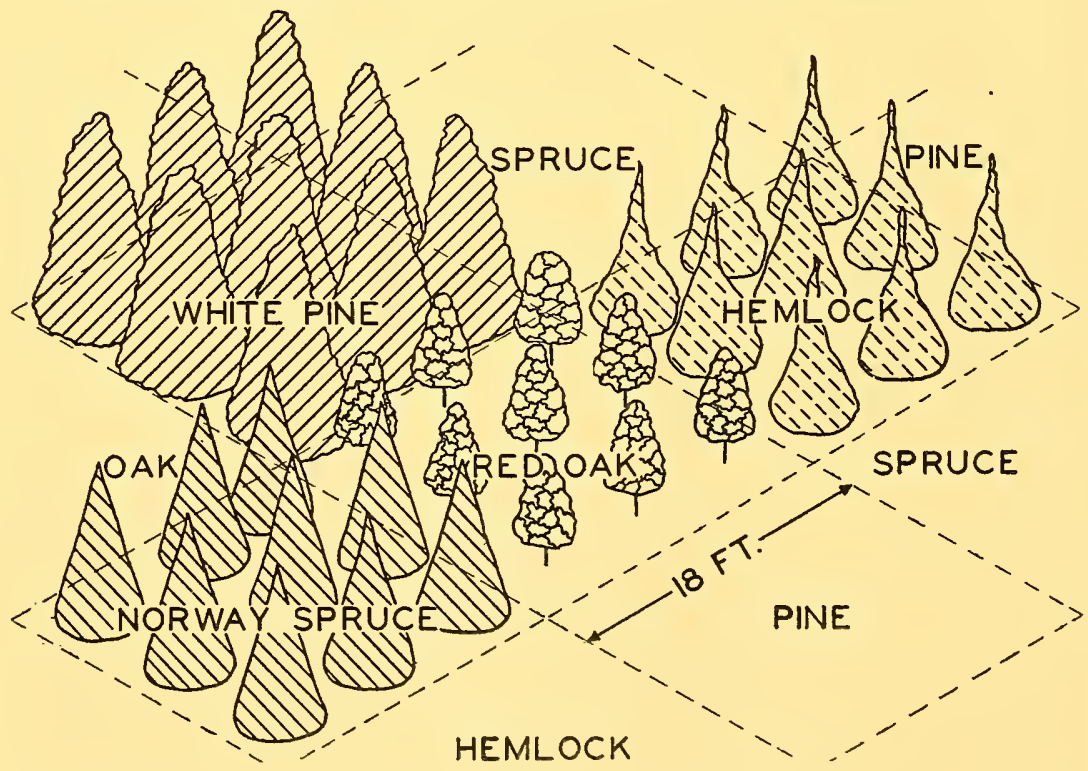


plained by the fact that mortality and expression of dominance in white pine stands is greater than in red pine, thus providing the individual trees with greater growing space both above and below ground.

\section{Natural Pruning}

Dying of the lower limbs should not be confused with natural pruning. The latter implies the disappearance of dead limbs from the tree that eventually occurs. How soon after death this happens depends primarily on the size of the limb and the pruning habit of the species. Natural pruning is of great importance commercially, since only after the limbs have fallen can the more valuable grades of lumber free of knots be produced by the tree. The pines and spruces under consideration are slow natural pruners (see Plates 5 and 6). Some of the lower limbs (those starting in the lower 16 feet of the bole) often attain a diameter of over an inch before dying. Such limbs frequently do not drop until the plantation is 40 to 60 years of age and not always then. Since the age at which these plantations should be harvested for timber is likely to fall between the sixtieth and eightieth years, it is evident that relatively little natural pruning can be expected. Even though a short section of the trunk may be free of limbs when the tree is harvested, the zone of clear wood between the bark and the overgrown limb stubs will be so narrow that boards free of knots cannot be obtained from the log. To illustrate conditions in the older plantations available, branches were counted and their diameter recorded for to trees each of red pine, white pine, and Norway spruce for the section of the trunk included in the first 7 feet above the ground. The first limbs to die are in this section and here, if anywhere on the stem, natural pruning should be in evidence, extending from the ground level upward. The results are shown in Table 8. All the limbs found were dead. Natural pruning has not as yet taken place to appreciable extent. The length indicated as free of branches, even on red pine, is so small as to be negligible since distance between branch whorls alone might be the cause.

Red pine should self-prune more quickly than white pine or Norway spruce. This is indicated by the comparative condition of the limbs. On the red pine trees the limbs measured were classed as partially decayed. A type of dry rot was present, the ends of the limbs frequently had dropped off, the bark had in most cases fallen, but the limb stubs still required force to break them off. The conclusion was reached that red 
pine stands would have to be at least 40 years old, and preferably older, before natural pruning took place over the first log length (see Plate 9).

White pine limbs were classed in most part as sound but a small proportion as partially decayed. The outer ends of the white pine branches were gone although a few branches are still 4 feet in length. The white pine branches are not only sounder but range up to larger diameters than those of red pine, although the average diameter is slightly greater for the latter species. At 60 years in white pine plantations natural pruning of the first log length is not likely to be completed.

Norway spruce develops side branches not only at the so-called branch nodes but also at points between the whorls. The spruce limbs, in spite of averaging much smaller in size than those of red and white pine, are sounder than those of either of the pines and were still nearly intact and in many cases 5 feet long (see Plate 6).

The shade-enduring characteristic of the spruce in contrast to the pines, particularly red pine, enabled the spruce limbs to remain alive longer than was the case with the pines. Norway spruce cannot be expected to prune naturally any sooner than white pine. As concerns number of limbs, red pine has the lowest number on the first 7 feet of stem, white pine nearly twice as many as red pine, and Norway spruce approximately double the number on white pine.

\section{Differentiation into Crown Classes}

As the competition between the individual trees becomes severe some trees outstrip others in height and crown spread and gain a dominant position in the stand. This aspect of the struggle between trees is termed "differentiation into crown classes." Four crown classes are customarily recognized as follows: Dominant, codominant, intermediate, and overtopped. 7 These names are self-explanatory of the relative position in the stand, of the height, diameter, and degree of shading characteristic of the various individuals. The first class is, as its name implies, in the best position, being taller, larger, and obtaining more light than trees of the other classes. Overtopped trees are for practical purposes completely out of the competitive struggle.

Early differentiation into crown classes, or rapid expression of domi-

7. Definitions of these standard crown classes can be found in forestry textbooks and glossaries. 


\section{NATURAL CYCLE OF DEVELOPMENT}

TABLE 8. AVERAgE NUMBER OF BRANCHES ON THE STEMS OF RED PINE, WHITE PINE, AND NORWAY SPRUCE IN THE FIRST 7 FEET ABOVE THE GROUND IN PLANTATIONS WITH SPACING OF 6 в 6 FEET. BASED ON IO TREES OF EACH SPECIES MEASURED IN PLANTATIONS ESTABLISHED 28 YEARS (RED PINE) AND 29 YEARS (WHITE PINE AND NORWAY SPRUCE)

\begin{tabular}{|c|c|c|c|c|}
\hline \multirow{3}{*}{$\begin{array}{c}\text { Diameter } \\
\text { of brancb, } \\
\text { incbes }\end{array}$} & Red pine & \multicolumn{2}{|c|}{ Wbite pine } & Norway spruce \\
\hline & \multicolumn{4}{|c|}{ Aoerage number of brancbes per tree } \\
\hline & $\begin{array}{l}\text { Partially } \\
\text { decayed }\end{array}$ & Sound & $\begin{array}{c}\text { Partially } \\
\text { decayed }\end{array}$ & Sound \\
\hline O.I & 0.6 & 4.1 & 0.4 & 19.3 \\
\hline 0.2 & 1.3 & I.6 & 0.3 & I 5.5 \\
\hline 0.3 & I.I & 3.2 & 0.8 & I 4.4 \\
\hline 0.4 & 2.5 & 4.6 & 1.2 & I 4.2 \\
\hline 0.5 & 2.3 & $5 \cdot 4$ & 1.2 & 12.4 \\
\hline 0.6 & $4 \cdot 3$ & $4 \cdot 4$ & 0.7 & $7 \cdot 4$ \\
\hline 0.7 & 4.6 & 3.2 & 0.4 & 2.8 \\
\hline 0.8 & 3.5 & 3.2 & 0.3 & 1.2 \\
\hline 0.9 & 2.2 & 2.I & & O.I \\
\hline 1.0 & 0.8 & 2.3 & 0.1 & 0.1 \\
\hline I.I & 0.6 & 0.7 & O.I & 0.1 \\
\hline 1.2 & & 0.5 & & \\
\hline 1.3 & & 0.2 & & \\
\hline I. 4 & & 0.3 & & \\
\hline Total & 23.8 & 35.8 & 5.5 & 87.5 \\
\hline $\begin{array}{l}\text { Average length in } \\
\text { feet of stem } \\
\text { naturally } \\
\text { pruned } \\
\text { Average diameter, } \\
\text { inches }\end{array}$ & $\begin{array}{l}0.5 \\
0.62\end{array}$ & & & $\begin{array}{l}0 \\
0.33 \\
\end{array}$ \\
\hline
\end{tabular}

nance as it is sometimes described, is desirable in a plantation. The majority of the trees which are originally planted cannot be allowed to grow until the crop is harvested. The object is rather to concentrate growth upon a few stems which will be developed to large size. If differentiation into crown classes occurs early, rapidly, and without excessive competition among the best dominant and codominant trees the general health and vigor of the stand will be better than in stands where differentiation comes late, is slow and accomplished only by an intense struggle between a considerable number of evenly matched individuals in the two upper crown classes.

Differentiation into crown classes starts earlier in white pine and Norway spruce plantations than in those of red pine. Appreciable differences in height growth and crown development among the individual 
trees appear before the young spruce and white pine plantations have formed forest canopies. By the time the canopy is closed differentiation into crown classes is already apparent and there is no danger of stagnation in growth from too prolonged and severe competition between dominant and codominant trees. Spruce develops even better in this respect than does white pine.

In contrast, red pine trees in early life grow in height with remarkable uniformity and come to the period of crown closure with a large proportion of the trees equal in height. This results in very even and severe competition between trees in the two upper crown classes and, while some of the poorest individuals are soon overtopped, most of the dominant and codominant trees continue to compete evenly.

On the whole, crown class differentiation advances with sufficient rapidity and to such a degree that no serious stagnation of growth, or mutual self-weakening of the better trees through intensive competition, need be feared in either white pine or Norway spruce plantations. This cannot be said in respect to red pine plantations with an original spacing of 6 by 6 feet, for there serious injury from too intense competition is likely to occur unless remedial treatment is provided. The best method of prevention is to plant at spacing wider than 6 by 6 feet. Red pine plantations in which the trees are spaced 8 feet apart will escape such stagnation.

Competition between individual trees continues throughout life but in plantations, once a well-marked differentiation into crown classes has taken place, there is relatively little danger afterwards that intensive competition between the better trees will be so even as to threaten stagnation of growth.

Table 9, showing distribution of trees by crown classes at different periods since planting on three sample plots in Norway spruce, red pine, and white pine plantations, illustrates the progress of differentiation in to crown classes.

Red pine is a hardy tree and when planted on grass-covered fields survives the difficult conditions better than either white pine or Norway spruce. For example, data in Table 9 show that 10 years after establishment, out of the $I, 200$ trees planted per acre, $I, I 64$ red pine were alive in contrast to I,088 Norway spruce and only 896 white pine. Twenty years later nearly half the white pine had died in the competitive struggle for existence, about one-third of the red pine, but only approximately onesixth of the Norway spruce. The Norway spruce is so much more shade- 
TABLE 9. NUMBER OF TREES PER ACRE BY CROWN CLASSES AT VARIOUS PERIODS AFTER

PLANTING IN SAMPLE PLANTATIONS OF WHITE PINE, RED PINE, AND NORWAY SPRUCE

\begin{tabular}{|c|c|c|c|c|c|c|}
\hline \multirow{2}{*}{ Species } & & \multicolumn{5}{|c|}{ Years since establisbment } \\
\hline & & ro & 15 & 20 & 25 & 30 \\
\hline \multirow{5}{*}{$\begin{array}{l}\text { White pine } \\
\text { Plot } 13\end{array}$} & Number of living trees & 896 & 896 & 744 & $54^{2}$ & 450 \\
\hline & $\begin{array}{l}\text { Percentage of total by crown } \\
\text { classes }\end{array}$ & & & & & \\
\hline & Dominant and codominant & 100 & 81 & 62 & 71 & 67 \\
\hline & Intermediate & & 13 & 33 & 22 & 30 \\
\hline & $\begin{array}{l}\text { Overtopped } \\
\text { (at the end of the } 23 \mathrm{~d} \text { year } \\
80 \text { dominant and codominant } \\
\text { trees and } 20 \text { intermediate } \\
\text { trees were removed in a } \\
\text { thinning) }\end{array}$ & & 6 & 5 & 7 & 3 \\
\hline \multirow{5}{*}{$\begin{array}{l}\text { Red pine } \\
\text { Plot 2I }\end{array}$} & Number of living trees & 1,164 & I , I I 7 & 955 & 896 & 795 \\
\hline & $\begin{array}{l}\text { Percentage of total by crown } \\
\text { classes }\end{array}$ & & & & & \\
\hline & Dominant and codominant & 100 & 83 & 85 & 69 & $6 \mathrm{I}$ \\
\hline & Intermediate & & 17 & 12 & $2 I$ & 25 \\
\hline & Overtopped & & & & 10 & 14 \\
\hline \multirow{5}{*}{$\begin{array}{l}\text { Norway } \\
\text { spruce } \\
\text { Plot I } 5\end{array}$} & Number of living trees & 1,088 & 1,088 & 1,083 & $\mathrm{I}, 048$ & 911 \\
\hline & $\begin{array}{l}\text { Percentage of total by crown } \\
\text { classes }\end{array}$ & & & & & \\
\hline & Dominant and codominant & 100 & 86 & 72 & 68 & 65 \\
\hline & Intermediate & & 13 & 27 & 20 & $3 I$ \\
\hline & Overtopped & & I & I & I 2 & 4 \\
\hline
\end{tabular}

enduring than the red pine that after the stand closes the rate of death from crowding is slower for the spruce. There is, however, less reason to fear stagnation of growth in the spruce than in the red pine stands, because an excellent differentiation in to height classes takes place in the spruce stands, avoiding too even competition between a large number of dominant trees. However, so many codominant and intermediate trees live on for long periods and press the dominant crop trees on the sides that the diameter growth rate (although not stagnating) is reduced to a level lower than desired. By the time the spruce stand is 35 to 40 years. old a thinning to keep the diameter growth rate at a satisfactory figure on the crop trees will be necessary.

In red pine stands the dominant and codominant trees show only a narrow range in total heights and consequently compete with one another on too even terms and reduce the diameter growth rate to such a low level as to endanger the vigor of the trees (termed stagnation of growth). 


\section{Prediction as to Ultimate Natural Course of Development}

The older plantations in the Eli Whitney forest are, with the exception of a few small areas, around 30 years of age. From this age they range down to those recently established. Since these plantations are not likely to be harvested before reaching 60 years of age, evidently full experience is lacking for the last half of their natural cycle of development. Certain predictions can however be made with a reasonable degree of assurance. It appears inevitable that as time passes tree and lesser vegetation characteristic of the original forest will seed in and become established beneath the planted trees. The tree species most likely to seed in first are the white ash, sugar maple, red maple, red oak, black cherry, and hemlock. Treatment of the plantations which in any way opens the forest and admits light to the forest floor will expedite this ecological change toward the forest vegetation native to the region. Already there are clear indications of the start of this process.

Even without intentional treatment by the forester, small openings in the forest canopy due to accidental causes are sure to occur and to become filled with natural reproduction, chiefly of hardwood species. Any openings made by cuttings will accelerate the development of hardwood reproduction. Undoubtedly the planted spruce and pines will themselves scatter seed and produce seedlings but the bulk of the natural reproduction will be of the native hardwoods. These hardwood species grow faster in height during early youth than do the pines and spruces and even though they may not outnumber the latter, they succeed in overtopping the conifer seedlings. Since the pines are less tolerant of shade than many of the hardwoods such overtopping may prove fatal. The spruces often live on under shade for many decades.

If left undisturbed to the play of natural forces the plantations of pine and spruce undoubtedly would be converted eventually into a forest of hardwoods with a mixture of hemlock and only a scattering of pine or spruce.

\section{EFFECT OF THE PLANTATIONS ON SOIL CONDITIONS}

W ITH replacement of the herbaceous and shrubby vegetation, characteristic of recently abandoned old fields, by forest plantation stands an entirely new environment is created. Changes naturally 
ensue which, in the course of time, result in reëstablishment of a forest soil profile.

The most obvious influence of a plantation on the soil is the redevelopment of an $A_{0}$ horizon (top soil layer) consisting of unincorporated organic matter, principally needles. This horizon is lacking in old fields because of the small amount of litter added annually to the mineral soil surface. As indicated earlier a continuous forest floor does not develop until a closed forest canopy has formed, usually io to I 5 years after the stands were planted. When white pine stands are 25 years old an $A_{0}$ layer I.O to 2.0 inches thick has accumulated; under red pine of the same age the layer is slightly thicker. The dry weight of the forest floor under white pine plantations 25 years old usually varies between 7,000 and I 5,000 pounds per acre. In red pine stands the amount of litter is somewhat greater. From the standpoint of water conservation the development of a layer of organic debris on the mineral soil is a very desirable feature.

Studies by Ralph L. Demont ${ }^{8}$ show that physical and chemical properties of the mineral soil in conifer plantations, 25 to 30 years old, are not significantly different from those of the soil in adjacent old fields. This may be explained by the fact that the plantations are still young and that sufficient time has not yet elapsed for their full influence to be manifested. The old field soils concerned have suffered very little erosion and have not deteriorated under agricultural use to the extent that soils have in many other parts of the country. Consequently, the early changes to be anticipated as a result of reforestation are small.

All evidence available at present points to the fact that sound soil conditions can be maintained under pure stands of the conifers now being grown in the Eli Whitney forest. With proper application of thinnings there is no reason to fear that the productive capacity of the soils will be impaired.

One of the effects of thinnings in conifer stands will be to hasten the development of native herbaceous and shrubby vegetation characteristic of natural forests in southern New England. The litter of these plants is, in general, relatively rich in nutrient materials and decomposes readily, having much the same effect on the soil as do leaves of hardwood tree species. Consequently, even if no hardwood trees are

8. Soil changes under pine stands on old fields in Connecticut, by Ralph L. Demont. Unpublished thesis in the library of the Yale School of Forestry. 1940. 
present in the conifer plantation - a condition which will seldom existlesser vegetation will contribute to maintenance of soil fertility. A pine or spruce plantation with a rich lesser vegetation may, from a biological point of view, be regarded as a mixed stand.

\section{PROBABLE YIELD OF TIMBER}

$T \mathrm{~T}$ is impossible from experience to accurately appraise the productive 1 capacity of spruce and pine plantations in the Eli Whitney forest, since the oldest plantations have attained only about half the age thought necessary to produce the most satisfactory timber yields. There are indications which lead the authors to believe that 40,000 feet, board measure, of square-edged lumber may be expected, as the yield per acre 60 years after planting, from properly stocked and managed plantations of Norway spruce and white pine in southern Connecticut. Red pine plantations at the same age if unaffected by the European pine shoot moth probably will yield at least 24,000 feet, board measure.

As yet no tables estimating the timber yields of pine and spruce plantations in southern Connecticut at different ages have been prepared. Tables showing the volumes in feet, board measure, of individual trees (up only to the maximum sizes found at the time of measurement), are available for plantation-grown white and red pines. These tables will prove useful in computing the volumes of specific stands, less than 30 years of age, in which the number of trees of different diameters and heights have been measured. (See Tables I6 and 17 in the Appendix.) The lack of old plantations, at the time the measurements for constructing these tables were taken, prevented obtaining values for felled trees larger than 12 inches in diameter breast height for white pine and 9 inches for red pine. Individuals at least 2 to 3 inches larger could now (I943) be obtained. A table showing total heights of white and red pine trees of different diameters may also be found in Table I 8 in the Appendix.

Volumes for three sample plots (numbers I2, I3, and I4) taken in the older white pine plantations and in one Norway spruce plantation (number I 5), have been worked up by applying the volume tables just mentioned and the results are shown in Table IO. Also shown in this table are data secured in a 57-year-old plantation located at Greenfield Hill, Conn., about 30 miles from New Haven, and data obtained from a 62-year-old sowing of white pine, known as the Shaker Pines, located 
about 50 miles north of New Haven. The volume data in Table io have been plotted over age in Figure 6 and a curve of estimated yield projected forward up to the age of 60 years. The data are of course too fragmentary to give more than an indication as to future yields. The Greenfield Hill plots are closely comparable in site conditions with those characteristic of the plantations in the Eli Whitney forest. The Shaker Pines are on sandy soils and represent a site of somewhat lower productive quality. The Davis plantation was located in northeastern Connecticut.

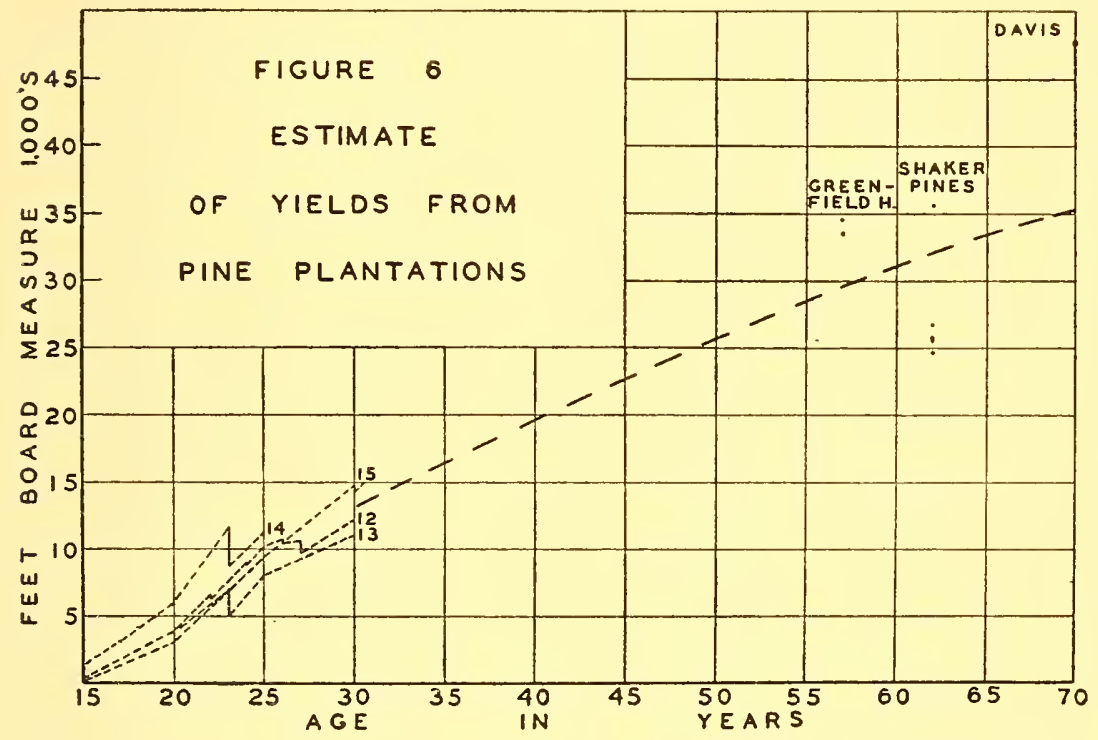

As shown in Table Io mean annual growth at 30 years, expressed in feet, board measure, amounted to 440 and 470 board feet on two of the white pine plots and 480 board feet on the Norway spruce plot. One of the white pine plots showed mean annual production of 570 board feet. An early thinning at the sixteenth year is considered the chief cause of the relatively high growth on this plot. Growth in lumber volume (board foot unit) takes place at a relatively slow rate during the first 30 years of a plantation's life as compared with the second 30 -year period. This point is illustrated by the curve of estimated yield in Figure 6. Consequently, it is not unreasonable to expect mean annual grow th of 650 to 700 board feet over the entire 60-year rotation, giving the estimated yield of 40,000 
feet, board measure, at that age for both white pine and Norway spruce. This is only slightly greater than the volume of the 57-year-old Greenfield Hill plantation, which has not been properly managed.

Successive thinnings systematically made throughout the rotation will have an important part to play in raising mean annual growth to nearly 700 board feet.

Observations on the Yale forest near Keene, N.H., made over the last two decades in connection with harvesting naturally reproduced stands of white pine have shown that untreated stands of natural origin have produced yields of 500 to 700 feet, board measure, mean annual growth per acre. Furthermore, the soils at Keene, on which such production was obtained, are of lower productive quality than those on which pine usually is planted in southern Connecticut. These naturally reproduced untreated stands, because of their much denser stocking and consequent slower diameter growth as compared with plantations, may be expected to furnish smaller yields of lumber at 40 to 80 years of age than wellmanaged plantations.

In Table I I data concerning volume growth from three sample plots in red pine plantations and from two plots in mixed red and white pine plantations are given. Growth is evidently slower than in the white pine and Norway spruce plantations. Mean annual production per acre at the twenty-eighth year varied in the red pine plots from 190 to 360 board feet. By the sixtieth year the mean annual growth should rise to 400 board feet per acre, giving the estimated total yield of 24,000 board feet per acre. These red pine plots were all in plantations with original spacing of 6 by 6 feet. The competition between individual trees has been so even and severe, particularly in Plot $\mathrm{I} 7$, which has not been thinned, that diameter growth has been curtailed, and as a consequence growth per acre has been kept at a low point. Closely spaced red pine plantations will need early thinnings in order to secure a yield of 24,000 board feet at 60 years. With an original spacing of 8 by 8 feet or with an early thinning in the more densely stocked stands such a final yield should be readily obtained from red pine plantations.

As yet neither white pine, red pine, nor even Norway spruce can be sold as pulpwood in southern Connecticut. It is quite possible that within the next ten years this situation may change. If and when pulpwood of the pines and spruces becomes salable a profitable market for material removed in early thinnings will be available, which should have the effect of increasing total yields per acre. 
PROBABLE YIELD OF TIMBER

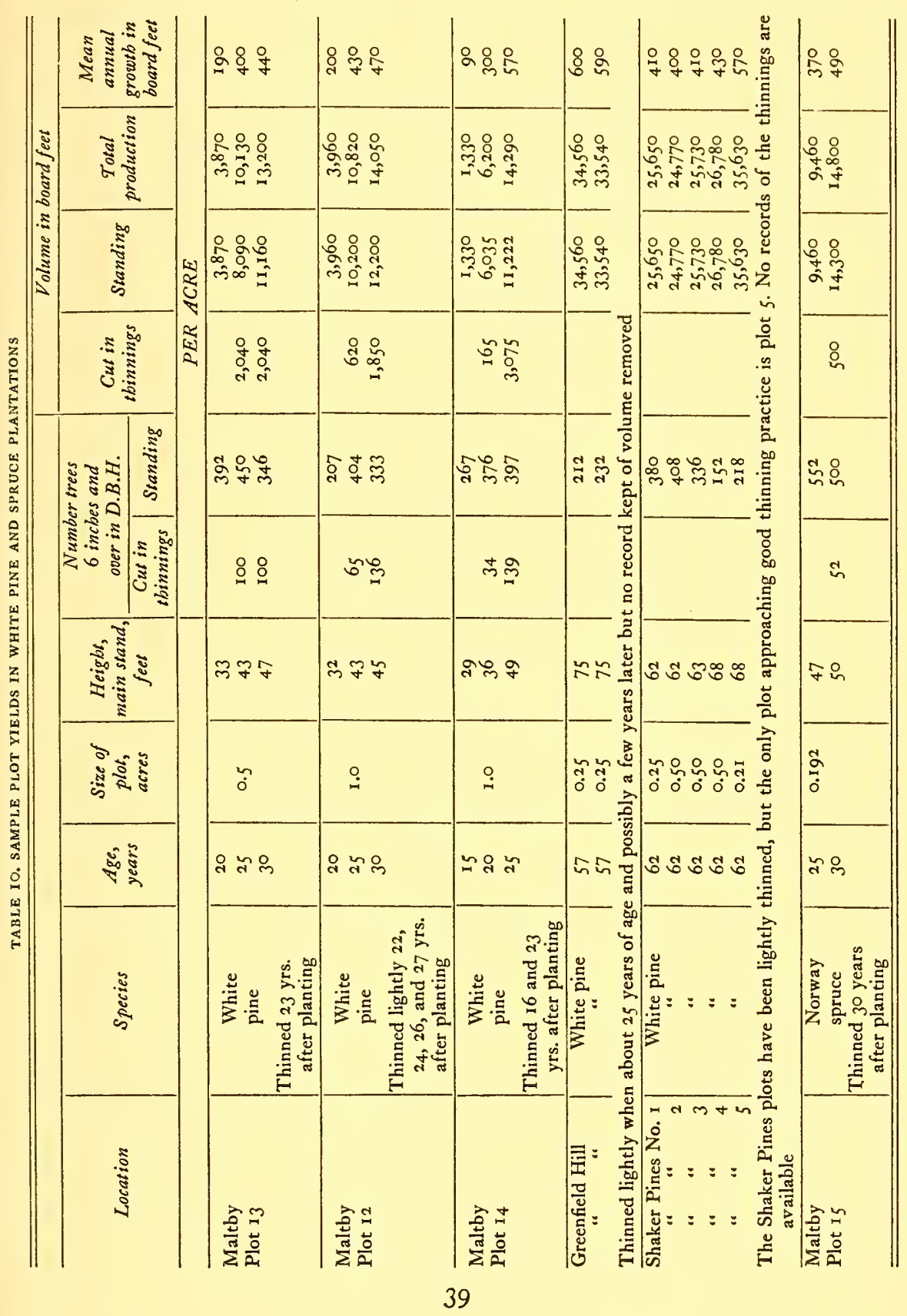




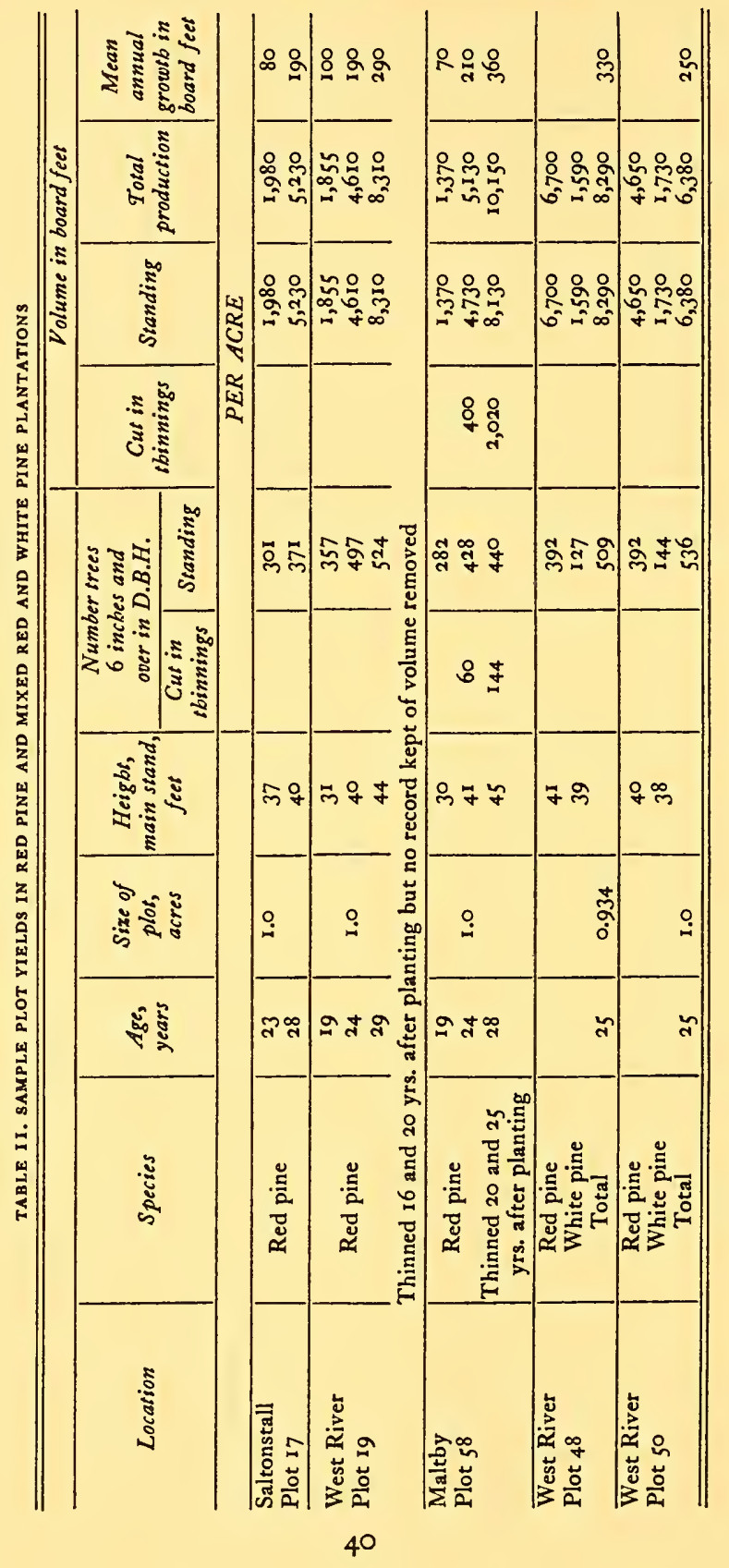




\section{PLANTATION MANAGEMENT}

DLANTING may be undertaken for a variety of objectives and the 1 details of management often will differ, depending upon the purpose for which the plantations were established. The planting of old fields in the Eli Whitney forest was done primarily in order to establish a protective forest cover on open lands, thus improving conditions of stream flow, and in doing so, to develop a type of forest which would produce timber of commercial value and ultimately make the investment financially profitable. The production of timber yields on lands utilized primarily for protection of watersheds is quite feasible under the soil and climatic conditions existing in southern Connecticut. The effect of any contemplated commercial management practices upon watershed protection has to be considered, but in the majority of cases needs little if any modification to afford adequate protection to the watersheds.

The establishment of plantations has already been considered and their subsequent management may now be discussed. After plantations are established their management may be divided into three classes of work, namely:

Protection against agencies threatening injury, cultural operations with the object of increasing the amount and value of the crop, and harvest of the mature timber with provision for the establishment of a new crop.

Protection and cultural operations are overlapping in time of execution and are continuously in the mind of the forester from the date of establishment until the crop is ready to harvest. For purposes of discussion the three classes of work are best taken up separately.

\section{PROTECTION AGAINST AGENCIES THREATENING INJURY}

$\mathrm{D}$

IRECT expenditures for protective measures, which might be appropriate in caring for ornamental trees, must be kept at a minimum in dealing with large areas of forest plantations and results must be secured through less expensive measures. Control of forest fires is of course as necessary for the planted as for the natural forest. Since the conifer plantations form a small proportion of the total forested area their protection from fire is provided for along with that for the rest of the property, and not having any features peculiar to plantation management need not be discussed at this time. 
Domestic animals generally should be excluded from forest plantations because of the damage they do in browsing and breaking small trees and in compacting the soil or starting erosion. However, before the forest canopy has closed a small number of grazing animals carefully restricted as to number, kind, and season of use may in some cases serve a useful purpose by grazing the herbaceous vegetation, thereby reducing the fire danger and the competition between herbs and trees. It should be borne in mind that the danger of injury by the animals to the planted trees is so great as to require careful consideration of each case before grazing animals are admitted to a plantation.

Goats should never be admitted to conifer plantations and horses are undesirable. Cattle do less damage but should be allowed in conifer plantations only during the growing season when plenty of palatable grasses or herbs are available for food.

Every species of tree has plant pests (principally fungi or insects) which attack it during some stage of its life. A few of these enemies may assume major importance, while the majority play only a minor role. Only the enemies of major importance need consideration here. In the following pages the various plant pests likely to become of critical importance in the development of a plantation are described and measures for their control are suggested. These include among fungi: Fomes root fungus, white pine blister rust, and Tympanis canker, and among insects 9 four species which are distinctly pests of young trees, becoming innocuous in older stands, namely, white pine weevil, European pine shoot moth, gall aphids, and the mound-building ant.

\section{White Pine Blister Rust (Cronartium ribicola Fischer)}

This foreign disease has been found in a few plantations in the Eli Whitney forest. Its characteristics and effects have been exhaustively described $^{10}$ and need no further comment here, except to note that unless the proper precautionary measures are taken serious damage may be anticipated in white pine plantations.

White pine nursery stock imported from Germany in I 909 and I 910 is known to have included a few trees infected with the blister rust and

9. The section dealing with insects is based largely upon information furnished by Dr. Roger B. Friend, State Entomologist of Connecticut, and by Stephen $H$. Spurr.

10. The blister rust of white pine, by P. Spaulding. U.S. Dept. Agr., Bur. Plant Industry, Bul. 206, 1911. 
other sources of infection have assisted in establishing the disease. Fortunately in southern Connecticut there are relatively few currant and gooseberry bushes, the host plants from which blister rust may spread to white pines. Ecological conditions of southern Connecticut are not favorable for abundant distribution of native wild species of currants and gooseberries, while areas containing abundant cultivated plantings of currants and gooseberries are limited in number and usually not in close proximity to pine plantations. These conditions, particularly the scarcity of wild currants and gooseberries, have made it possible to grow white pine timber in this region without excessive costs for blister rust control. The usual methods of control, namely, eradication at intervals of five to ten years of currant and gooseberry bushes within 300 to 900 feet of pine plantations have kept, and promise to keep, losses from blister rust at a negligible figure. The necessary width of the zone around the pine plantation from which currant and gooseberry bushes are eradicated varies with the density of the vegetation screening the plantations. In open country the full 900 feet might have to be freed, while, if a dense high belt of shrubs and trees separates the currant and gooseberry bushes from the pine, the zone of eradication may be greatly reduced.

Beginning in I9I7 several eradications of currants and gooseberries have been made in the Eli Whitney forest. One eradication is not enough, since new bushes originate from seeds distributed by birds, and always some bushes are overlooked in an eradication operation. In addition to eradication of currants and gooseberries white pine trees infected with blister rust are cut out whenever found. Very little of this work has had to be done. Costs of eradication are estimated by J. Edwin Riley, Jr., of the U.S. Bureau of Entomology and Plant Quarantine at 6 cents per acre of pine per year as an average throughout the life of the crop.

\section{Fomes Root Fungus (Fomes annosus [Fr.] Cke.)}

Fomes root fungus is one which enters the tree through dead roots eventually destroying the root system and working up into the lower stem where it causes a rot in the heartwood. Trees once attacked cannot be saved. As yet this rot has appeared only on an occasional isolated white pine tree in plantations from 15 to 25 years of age. If it became prevalent and attacked solid clumps of trees, the damage might be severe, as has been the case in some other parts of the world. It is hoped 
that in plantations made on old fields Fomes annosus, or other root rot fungi, will not become distributed abundantly and cause damage on a large scale during the first 60-year rotation. The potential destructive capacity of this disease may prove to be an argument against the repeated use for several rotations of planted conifers on the same ground. Fomes root fungus may attack any of the pines and spruces commonly planted. Boyce ${ }^{\text {II }}$ believes that vigorous trees are seldom attacked by the disease. The occasional trees killed should be cut and burned.

\section{Tympanis Canker}

The Tympanis canker of red pine has been found in red pine plantations in the Eli Whitney forest. ${ }^{12}$ While having caused serious injury within a few small areas, the disease is now recognized as being of secondary importance and susceptible of complete control by good plantation management. Such management consists either in thinning dense red pine stands (those planted with spacing as close as 6 by 6 feet) early enough to prevent excessive competition between the trees, or else in spacing the trees 8 by 8 feet apart in all new plantations.

The following quotation from Hansbrough's conclusions indicates the character of the disease.

A new disease of red pine has recently been found in southern Connecticut, Rhode Island, eastern Massachusetts, western and central New York, northern New Jersey, eastern Pennsylvania, central Ohio, and southern Michigan. It is of serious consequence only on plantation-grown red pine, but it also occurs occasionally on eastern white pine. On the former host it is characterized by axially elongated, annual main-stem cankers which are always centered at the nodes. Infection takes place through adhering lateral dead branches and the grow th of the fungus after it gains en trance to the stem is usually very rapid-i.e., cankers up to three feet in length may be formed in one year's time. Infection of red pine has been found only where the tree has been planted south of its optimum range.

The conclusion is reached that Tympanis sp. is a weak parasite of red pine and can only cause disease when the host is weakened by some environmental factor or complex of factors. The hypothesis is suggested that the presence of the disease only in plantations south of the optimum range of the host may be a result of the fact that a warmer climate exists there than is found within the optimum range of red pine. This warmer climate undoubtedly increases the injurious effects of a severe drought and thereby favors disease outbreaks.

Individual infected trees may be killed outright by the girdling of the main-stem or may remain alive indefinitely. A permanent disfigurement of the bole of the tree is the usual

11. Forest Pathology, by J. S. Boyce, p. 116, 1938.

12. The Tympanis canker of red pine, by J. R. Hansbrough. Yale University, School of Forestry, Bul. $43,1936$. 
result and may be effected through resin infiltration of the wood under the canker, through decay of the wood by secondary fungi gaining access through the open cankers, through the discoloration of the sapwood by staining organisms, or through the breaking of the main-stem at the cankers.

\section{White Pine Weevil (Pissodes strobi Peck)}

The white pine weevil is a serious obstacle to the production of high grade pine lumber in planted stands. For this reason it is considered at some length in the following pages. The larvae kill the leading shoot of the tree during late spring and early summer, and one or more of the lateral branches from the uppermost living whorl (the so-called weeviled node) assumes a more or less perpendicular position and the function of the killed leader. This causes a definite crook in the bole. The same type of injury repeated several times may destroy the timber value of an entire tree.

Weevil attack begins when the trees are 2 or 3 feet in height ( 4 to 7 years old) and increases in intensity until they are 12 to 18 years old, decreasing from then on and becoming economically insignificant at the age of 25 to 30 years.

The adult weevils are attracted to the most vigorous leaders and oviposit in them in preference to more slowly growing trees. This means that dominant and codominant trees are most severely injured, often to such an extent that they are worthless from a lumber production standpoint. In the Eli Whitney forest a random sample of about I,300 trees showed that the weeviled trees average 5 per cent greater in diameter than the unweeviled trees. The size of the leaders also affects the weevil population, for there is a direct relation between the diameter of the leader and the survival of weevil larvae. The highest survival occurs in the larger leaders.

An abundance of vigorous leaders in the relatively open planted stands favors an abundance of weevils. The density of stocking in such stands is not conducive to rapid straightening of the stems. The preference of the insect for dominants and codominants results in injury to the best trees and either decreases the yield of lumber or lengthens the rotation of the stand or both. Concentration of weeviling on that part of the bole which forms the butt log is particularly serious, for nearly 50 per cent of the volume of a tree grown on a 60-year rotation is in this I6-foot butt log. The aim in plantations usually is the production of at least one $\log$ of high quality in each crop tree. 
Although a weevil attack causes slight losses in growth, these losses are insignificant compared to the depreciation in the quality of timber due to crooked and forked boles (see Plate 5).

If a wide bend, or offset, from the vertical stem is produced by the weevil injury, the crooked section will be unfit for sawing, and will have to be cut out of the tree bole when the latter is bucked into logs. This causes a loss in merchantable volume, which may be substantially increased, if the crooks are so near the ground or so close to one another as to leave in between only straight sections too short to have merchantable value.

Within the weeviled crook itself the branch knots will be somewhat larger than normal and cross grain and compression wood will be found. These defects are of course eliminated in the case of all crooks of such wide curvature as to require culling from the merchantable bole. In the case of small crooks which are ultimately so overgrown as to be indistinguishable externally, and require no culling of the tree bole when harvested, these defects may be hidden in the log. Fortunately no serious loss need be expected in such cases. The defects-extra large knots, cross grain, and compression wood-will be found only in a narrow core in the center of the tree which is of low quality even in unweeviled trees.

Investigations of Spurr and Friend ${ }^{\mathrm{x}}$ showed that compression wood extended vertically an average of 9.4 inches and horizontally $\mathrm{I} .9$ inches from the original pith line in the plane of offset at the weeviled node. They concluded that the horizontal extent of compression wood was only slightly in excess of the offset from the vertical due to weeviling. This is so small in trees which overgrow crooks as to be confined to a very few inches in the center of the stem, in a knotty section close to the pith.

The extent of crooked and forked bole in a weeviled tree depends on a number of factors, all of them more or less connected with the rapidity with which the stem straightens and the degree of straightening. In most cases the larvae confine their feeding to one internode, and a lateral from the uppermost healthy whorl of branches moves upward to function as a leader. The asymmetrical distribution of weight of branches at the weeviled node, which results from this process, causes the stem to bend slightly away from the new leader, and thus aids the straightening

13. Compression wood in weeviled northern white pine, by Stephen H. Spurr and Roger B. Friend. Journal of Forestry 39: 1005-1006. 194I. 
process somewhat. Asymmetrical radial growth takes place just above and at the weeviled node, gradually filling in the concave curvatures in the stem.

The most significant of these three processes is the actual upward movement of the dominant lateral, most of which occurs the first two or three years after weeviling and which accounts for most of the straightening. Certain conditions modify the extent of this movement. If the weevil larvae move downward through one node, then a lateral branch from the node below must assume the function of the leader. This lateral will be two years old and more "fixed" in position, hence less capable of straightening. The result is a greater crook in the stem and more frequent forking.

What has so far been said regarding the injury from weeviling presents the unfavorable side, but there are more favorable aspects to the situation. An important point is that in properly managed white pine plantations in southern Connecticut enough trees per acre unweeviled in the butt $\log$ usually can be found to fully stock the area. These trees of course are the ones selected for pruning and are favored in thinning operations.

Furthermore, the amount of horizontal offset in a stem ensuing as a result of a single weeviling in the butt log is usually less than 3 inches. Since the diameter of the stem is very small at the time of weeviling this offset will be completely filled in with compression wood before the stem grows to large diameter. Most or all of the compression wood in such cases will be in the central knotty core which even in unweeviled pruned trees will yield low grade lumber. Consequently in many cases trees weeviled once in the butt log can be selected as final crop trees.

It is anticipated that nearly all white pine trees will be weeviled one or more times during the 6o-year-long rotation. With careful selection of individuals for final crop trees the maximum extent of injury to these trees, caused by the weevil, should be represented by the cutting out between $\log$ lengths of 2 or 3 weeviled sections, each averaging less than I 8 inches in length. The white pine weevil need not prevent production of excellent timber crops of white pine in southern Connecticut (see Plate 23).

Reduction in weevil injury may be attained by decreasing either the number of weevil attacks per log length, or the effects of the attacks, or both. The weevil population is kept down to a certain extent by parasites, predators, and climatic conditions, but at present at least these 
factors are not subject to manipulation and hence little can be done to increase their effectiveness.

An essential for protection is that white pine should be planted only on good sites. Although the adult weevil is attracted to vigorously growing leaders, a long leader confines larval injury to one node, which facilitates straightening of the stem. The effect of larval injury extending through two nodes already has been mentioned. Another benefit derived from rapid growth is the shorter period during which trees are exposed to attack. Granting that the incidence of attack drops off after a height of about 15 feet is reached, then the sooner trees get beyond this height, the less the exposure to attack. Maughan ${ }^{14}$ in his report on the results of weevil control on the Eli Whitney forest, stated that on poor sites the method of control used would not produce enough suitable stems per acre to furnish a fully stocked stand for the final crop.

A dense stand, more than 1,200 trees per acre, theoretically decreases weevil injury by stimulating perpendicular growth. However, the expense of increasing the number of trees planted much beyond I,200 per acre usually is too great to permit the use of this method.

Growing pines among hardwoods has been recommended as a protective measure. The hardwoods should overtop the pines slightly. Theoretically this procedure lessens the chances of attack, but on the other hand the overtopped pines are appreciably slowed down in growth and a much longer rotation is required to obtain timber of a given size as compared with a pine stand free from hardwood cover.

One of the commonly practiced methods of control is the removal of infested leaders and their destruction by burning before the weevils emerge. This method has been used as the standard measure in the Eli Whitney forest for many years and, as brought out by Maughan, has here proved its worth. Under this method to secure protection against serious injury on good to medium sites, spacing in plantations should be as close as 6 by 6 feet and stands of at least 800 trees per acre should be established. To accomplish this may require an occasional replanting of blanks to bring the surviving trees up to the desired number per acre. However, a dense stand alone will not be effective in eliminating attack by the white pine weevil.

The white pine plantations are gone over each year in June or July

14. Control of the white pine weevil on the Eli Whitney forest, by W. Maughan. Yale University, School of Forestry, Bul. 29, $193^{\circ}$. 
when the larvae are actively feeding in the terminals. All infested tips are cut out and burned, thus destroying the larvae. The work is repeated each year until the stand is closed and the tree tops are reached with difficulty from the ground (a period 8 to Io years in length). Maughan estimated that on good and medium sites, by this type of treatment, enough acceptable stems per acre for a full crop could be obtained at a total cost of 5 dollars per acre.

Destruction of the larvae reduces appreciably the population of the insect and, where carefully done for a few years, usually reduces the amount of infestation. The method is particularly adapted for a region like southern Connecticut where white pine is a relatively rare tree in the natural forest, and consequently most of the white pine weevil population is concentrated in the plantations. In a region containing large areas of natural second-growth white pine the method might prove too expensive and also be ineffective because of heavy annual reinfestation of the plantations from natural stands. However, there is some evidencers that the method may be practical even in regions where white pine is abundant.

If white pine stands are wanted on poor sites planting of approximately 1,700 trees per acre ( 5 by 5 foot spacing) is advised in order to secure an early closing of the stand thereby lessening the injurious effects of weeviling.

In order to facilitate straightening of the stem, the clipping of all laterals but one at the weeviled node, at the time the infested leader is removed, sometimes is recommended. That this operation is beneficial is readily seen from measurements made at Branford in the Eli Whitney forest, and in the Yale forest at Keene, N.H. In I935, I7 weeviled trees at Branford were selected and on 7 of them all the laterals but one were pruned from the weeviled node. The other Io were not treated. In the fall of 1939 the pruned trees had an average offset of I.I 8 inches while the untreated trees had an offset of 2.28 inches. At Keene in the summer of 1937 all the laterals but one were pruned from io recently weeviled trees, all but two from Io trees (weaker of the two removed the following year), and to trees were left untreated. The results of this experiment were as follows:

15. Some work on the white pine weevil, by Robert P. Holdsworth. Journal of Forestry 4I: I43144, 1943. 


\begin{tabular}{lccc} 
& \multicolumn{4}{c}{ Offset in inches } \\
Treatment, 1937 & 1937 & 1938 & 1939 \\
ateral removed & 6.15 & 2.25 & 1.71 \\
laterals removed, weaker of the & & & \\
ed in $193^{8}$ & 7.56 & 3.56 & 2.20 \\
$t$ & 7.24 & 4.42 & 3.28
\end{tabular}

Although the difference in offset between the two treatments is not appreciable, both being satisfactory, the first treatment gives a better type of offset. However, there is always danger that the single new leader will be weeviled the year following treatment. Both methods are too expensive for general application in the forest. These data illustrate also how the stem straightens with the passage of time during the first two years subsequent to weeviling.

Since the best trees in the stand are weeviled most severely, an economical method of protecting such trees against attack, without retarding their growth by maintenance of an overhead cover is much to be desired. Recently Potts ${ }^{16}$ and his collaborators published the results of spraying the leaders in March or April with a concentrated insecticide. Using the following formula at the rate of 5 gallons per acre, they obtained excellent control.

$\begin{array}{lr}\text { Lead arsenate } & \text { I part by weight } \\ \text { Water } & \text { Io parts by weight } \\ \text { Oil (linseed, fish, etc.) } & 0.3 \text { parts by weight } \\ \text { Spreader }{ }^{17} & 0.02 \text { to } 0.03 \text { parts by weight }\end{array}$

The method was used successfully in 1942 in the Eli Whitney forest and may prove more economical than cutting out the terminals. One man can treat two acres per day. It may not be necessary to spray the trees more than two or three times during the life of any one stand. Direct control of an insect pest by spraying is not often justified from the economic standpoint. In this case it may prove to be cheaper and more effective than other methods of controlling the white pine weevil under southern Connecticut conditions.

The white pine weevil is sometimes a pest on Norway spruce, although

I6. The white pine weevil and its control by concentrated sprays, by S. F. Potts, A. C. Cline, and

H. L. McIntyre. Journal of Forestry 40: 405-410. 1942.

17. Aresket, Ultrawet, Santomerse D, or sodium lauryl sulfate. 
in southern Connecticut no severely injured stands have been observed. The injury caused by weeviling is of less consequence to a Norway spruce than to a white pine tree since in the former the stem straightens better, avoiding any pronounced crook.

\section{European Pine Shoot Moth (Rbyacionia buoliana Schiff.)}

In the southern part of Connecticut the European pine shoot moth has restricted the use of red pine in forest plantations. The larvae of this species bore in to the needle bases near the tops of the twigs in July, into the buds later in the summer, and in to the growing shoots the following spring. The infestation is concentrated in the tops of the trees, and the effect on the trees depends on its intensity. When the insect is scarce or only moderately abundant the loss of needles, buds, and shoots is not serious. However, a heavy attack leads to a serious loss of new growth. The terminal may be killed back about a foot in over 90 per cent of the trees in a stand; the development of latent buds results in extreme bushy growth, and injury to the leader may cause "post-horn" or "bayonet tip," a permanent distortion of the bole. In cases of excessive injury the tree literally stops growing, old foliage is lost faster than new foliage develops, and deterioration becomes marked. Plantations sometimes become injured beyond a point where recovery is possible.

Although red pine is the most important host in this region, Scotch pine is heavily infested, and Austrian pine to a less extent. Among ornamental pines the mugho is a favored host. So far as known white pine has never been seriously injured.

The abundance of the insect depends much on the stand conditions. If the earliest infestation occurs when the trees are 2 to 4 feet in height, then in about 3 or 4 years the trees may become noticeably injured. For example, in one 5-acre red pine plantation in Guilford the earliest known infestation occurred in one corner in 1937 on a few trees. By the summer of I $94 \mathrm{I}$ the insect had spread through the entire stand and many of the trees, then about 5 feet in height, were visibly injured. Damage became worse in 1942 . In another case very young trees were so severely injured by the time they reached a height of 6 to 8 feet that many appeared almost dead, the condition of the stand as a whole appeared hopeless, and the trees were cut down. On the other hand, there are many red pine stands in the Eli Whitney forest which first became infested after the trees had reached a height of about I $_{5}$ feet and closure had occurred. 
These trees have never been seriously injured, although supporting a very light insect population for years. Other stands, in which the infestation first appeared just before closure, have become quite badly injured but have recovered.

Such observations as these over a period of years have led to the conclusion that the height of the trees and the density of the stand affect the injuriousness of the insect. After a stand closes the infestation tends to decline, and if no serious infestation exists at this time, the trees probably will come through without severe injury. If the trees are small (in a 6 by 6 foot planting and less than 8 feet in height) when first infested, then the insect increases rapidly in abundance and severe injury will result. That the density of the stand is as important as the height is shown by the increase in infestation which occurs when a stand is heavily thinned, and by the greater prevalence of the insect on the edge of plantations over I 2 to 15 feet high.

No matter what the height of the trees, the infestation in red pine is concentrated near the top. This means that a relatively small insect population can cause much injury, and the population does not have to be any greater to injure a tree 20 feet high than to injure one 8 feet high.

Climate exercises an important influence on the shoot moth population. At $-18^{\circ} \mathrm{F}$. the larvae are killed after a very brief exposure, and the buds in which they hibernate offer practically no protection from the cold. Even temperatures of $-15^{\circ} \mathrm{F}$. have a noticeable effect in reducing populations. The lack of resistance to low temperatures is presumably the reason for the absence of severe infestations in central and northern New England. The effect of temperature may well be local, as some stands in any one forest may be exposed to lower temperatures than others.

Several species of imported insect parasites have been introduced into infested red pine stands in this region, but their effect has not been noticeable as yet except possibly in one case where about I 4 per cent of the mature larvae were parasitized by Orgilus obscurator Nees, a species of Hymenoptera. Native parasites of the shoot moth give no appreciable control.

The two direct methods of controlling the European pine shoot moth are pruning off the infested tips and burning them, and spraying. Both these methods are too expensive for use in forest plantations. As yet no economically practical method of control has been discovered. It is true that the pruning and burning method has been applied on a large scale in 
Connecticut by Government agencies. During the period 1934 to 1938 a great deal of control work was done by the Works Progress Administration and other Government agencies in red pine plantations in the Eli Whitney forest. Many plantations were gone over annually for several years and branch tips and terminals infested with shoot moth were cut off and burned. This work undoubtedly delayed the progress of the infestations and may result in the ultimate saving of some plantations. However, this type of work is so time-consuming and consequently expensive as to be an impractical method of control in producing timber crops. It can only be used where the Government is willing to provide funds and men for such work and only so long as adequate control of the men is lodged in a competent supervisory personnel.

Since red pine plantations in southern Connecticut cannot be protected at reasonable cost against injury by the European pine shoot moth, planting of this tree was discontinued in the Eli Whitney forest several years ago. Most of the older red pine plantations, those closed before 1930, probably will survive attacks by the shoot moth and produce good yields of timber.

\section{Eastern Spruce Gall Aphid (Adelges abietis L.)}

This aphid is an abundant pest in young Norway and white spruce plantations before the forest canopy closes and for some years thereafter. Inspection of a spruce plantation 5 to I 5 feet in height often suggests the idea that it will be ruined by the insect. Hundreds of deformed twigs on a single tree bearing the characteristic galls made by this insect give the impression of serious injury. In fact some trees are killed, others suffer a great reduction in growth, but on the whole the trees survive the annual attacks and after the stand closes increase their growth rate. There are two generations of the insect a year, one of which hibernates at the base of the buds and the other lives in galls formed at the base of the current year's growth. The galled twig may die, and usually does so when the gall completely encircles its base, or it may survive, the gall being later. sloughed. Trees highly susceptible to attack may be seriously injured, but on the other hand lightly infested trees are unharmed.

In Norway spruce plantations in southern Connecticut about onethird of the trees are immune to aphid attack. Although the winged adults may lay eggs on these trees in September and the young which hatch from these eggs may settle on the twigs, none of these young ever 
matures to lay eggs the following spring. Many trees have a low susceptibility to aphid attack, never having many galls in any one year. If we group the trees into two categories, (I) uninjured, that is, uninfested or lightly infested, and (2) injured, medium to heavy infestation, then about three-fourths are not injured to any practical extent by the insect. Moreover, the badly injured trees are predominantly among those of slow growth. Trees on a good site, and hence growing rapidly, appear to literally outgrow the insect. Rapidly growing trees, after attaining a height of about 15 feet or 20 feet, become less heavily infested at the top than on the lower branches. Thus, the most heavily galled trees are mainly suppressed individuals and represent a relatively small proportion of the whole stand.

On a good site and with full stocking, this aphid is not likely to be economically significant in the forest. Most of the trees severely injured will be among those that would normally be suppressed. In the average Norway spruce plantation a relatively small proportion of the trees will be heavily galled, and the more vigorously growing of these may throw off the effect of the insect.

Observations on white spruce in southern Connecticut have not been as extensive as those on Norway spruce, but in the Eli Whitney forest less injury apparently is done to white than to Norway spruce.

\section{Mound-Building Ant (Formica exsectoides Forel)}

The mound-building ant is a pest of young plantations, killing the trees and shrubs, particularly young pines, in the immediate vicinity of the mound. Affected trees have conspicuous bark lesions at the base. As the ant colony increases in size, the area around the nest in which trees are killed increases in extent. Open circles, about 40 feet in diameter, with an ant hill in the center, are quite common in plantations. Where several mounds are near by the area rendered blank may be considerably greater. The trees are reported by Peirson ${ }^{18}$ as being killed by injection of formic acid into the stem near the ground which results in girdling the tree. In some stands a considerable loss may ensue, particularly those growing on light, sandy soils where ant hills often are numerous and close together. The insect does not apparently seek out plantations in which to build

18. Mound-building ants in forest plantations, by H. B. Peirson. Journal of Forestry 20: 325-336. 1922. 
mounds, but is purely fortuitous there. The colonies originate in the plantation while the trees are small and the stand open.

Methods of control involve destruction of the ant colonies. A chemical such as carbon bisulphide or ethylene dichloride, which volatilizes and produces a gas heavier than air may be placed in the mound. 19 The gas should spread downward through the mound and kill the ants. The best time of year to treat the mounds is late in the fall after activity has ceased or early in the spring before it begins, since the ants will then be all inside the mound.

Summer treatment should be made when the atmospheric humidity is high and the barometric pressure low. In treating a mound several inches of material should be removed from the top, one hole made in the center and several on the periphery, the chemical poured into the holes, the material put back over the holes and tamped. Carbon bisulphide is inflammable, toxic, and rather awkward to handle, and ethylene dichloride also, being a liquid, is inconvenient to use.

Methyl bromide, 250 to $500 \mathrm{cc}$. per hill, has been found very efficient in killing colonies. ${ }^{29}$ This material is very volatile (must be kept in cylinders under pressure) and its vapors are toxic to man, so its use is limited. It does not present a fire hazard.

Ground derris (or cube) root, containing about 4.0 per cent rotenone, is very toxic to ants and has given promising results in a preliminary trial. The derris should be liberally spread over and around the mound during dry weather in the summer when the ants are active. A pound on a mound 6 feet wide and 12 feet long is suggested. This material is easy to handle and as cheap as any others under normal conditions. It should not be allowed to wash into streams or ponds, as rotenone is very toxic to fish.

The use of materials poisonous to warm-blooded animals in the forest has obvious objections and is not to be recommended.

\section{WILDLIFE}

Small rodents such as mice, rabbits, and squirrels have not acted generally as serious enemies of white and red pine and spruce plantations in this region.

I9. Experiments in simplified control of mound-building ants in the forest, by H. J. MacAloney and N. W. Hosley. Journal of Forestry 32: 1003-1006. 1934. 
It is true that on several occasions severe damage has been done to certain plantations. Mice have practically destroyed some, although not all, hemlock plantations made in grassy fields. On the same, and on similar areas, white and red pines and spruce have been injured to a very small extent. As a result of experience hemlock is now not planted on grassy fields unless provision is made to poison the mice. Hemlock can be planted successfully on cutover areas without poisoning.

Conifer plantations in this region are virtually untouched by rabbits, presumably because of the abundance of other preferred food. Hardwood reproduction on many areas is severely injured by rabbits, being either cut off or girdled. Most of the red oak seedlings in plantations and sowings are cut back, often several times, by rabbits. Ultimately a satisfactory percentage of oak seedlings become established in spite of the rabbits.

Until the last year or two squirrels have not caused appreciable injury to the conifer plantations. Recently some small plantations adjoining wooded areas have suffered from squirrel depredations. Injury has been principally to Norway spruce and consists in cutting of the terminals and side branches.

Deer occasionally cause damage in young conifer plantations by browsing and by breaking branches and tops. Except on a few areas where deer were concentrated the amount of damage done has been immaterial.

\section{CULTURAL OPERATIONS TO INCREASE AMOUNT AND VALUE OF THE CROP}

7 HE three types of cultural operations which can be advantageously

1 employed for the purpose of increasing crop values are (I) release of the planted trees from overtopping vegetation of worthless or inferior character, (2) artificial pruning of branches, and (3) periodic reduction of the number of trees per acre (thinning), in order to eliminate excessive competition for all final crop trees and to concentrate growth upon these trees. All of these measures must be considered in relation to cost as compared with the return expected from the crop produced.

\section{Release from Overtopping Vegetation}

Open old-fields are the areas which have been recommended for plant- 
ing (see page 40). Since these areas are unoccupied by trees at the time of planting, it would appear that there is little danger of overtopping vegetation threatening trees planted in open fields. Such is the case in many plantations. The planted trees after a few years of struggle with the herbaceous vegetation gain the ascendancy and form a forest cover free from overtopping vegetation of other tree species. There are many exceptions, however, where such overtopping does take place.

Sometimes the presence of small hardwood seedlings, bare of leaves in the late fall to early spring, scattered over an old-field escapes observation when the area is inspected as a possible planting site. These areas should not be planted but should be left to develop as natural hardwood stands. Once planted the tendency is to favor the planted trees as against the natural regeneration. This is justifiable provided the natural seedlings are of species useless or inferior for timber purposes such, for example, as alders, gray birch, sassafras, and red maple. Seedlings of species valuable for timber such as white ash, basswood, sugar maple, oak, and yellowpoplar can well be left to form a mixture with the planted conifers.

On some old-fields, entirely without trees at the time of planting, seedlings of rapid-growing species, usually of low timber value, become established naturally after the area is planted and, surpassing the planted trees in height growth, soon overtop the latter. Overtopping vegetation may consist not only of tree species but also of vines such as bittersweet (Celastrus scandens L.), poison ivy, grape (Vitis spp.), and greenbriar (Smilax rotundifolia L.). Such vines frequently climb into the treetops and deform and even kill individual trees.

Control of overtopping vegetation to be most effective, which implies the least possible interference with planted trees and the least expenditure for removal of the undesirable plants, should be started early when the stems are small. Ordinarily the plants to be removed have no sale value. Consequently the release of the planted trees from overtopping vegetation requires a direct financial outlay, to be returned only after a considerable period of time through increased timber production as a result of the operation. This situation renders it necessary to keep ex-. penses at a minimum. The method of work most suitable for conditions in young plantations is the cutting of the inferior stems, which either are overtopping or evidently will very shortly overtop the planted trees. Distinction must be made between overtopping and crowding from the side. The latter condition is wanted since it assists in forming a forest canopy and in accomplishing natural pruning of the lower limbs. What 
is to be avoided is the actual overtopping of a good by a poor tree or by a vine. Knowledge of the relative height growth of the species in the stand is essential to a correct understanding of the danger of overtopping between any two stems. With workers unskilled in the operation the tendency is to cut far too many stems and consequently to make the cost per acre excessively high. It is better policy to make a single release cutting too light rather than too heavy, and plan to return for a second cutting if necessary within two or three years.

A variety of tools have been employed in the work. When done at the proper time the stems to be cut will average less than an inch in diameter and the space in which to swing a tool is likely to be restricted. Hence a cutting tool of the machete type is likely to prove most efficient. Whether more than one cutting will be needed depends, not only upon the degree of severity of each cutting, but also upon the relative height of the trees cut and those left. Many of the inferior species are vigorous sprouters, and may grow so rapidly as to catch up with and overtop for a second time the trees it is desired to save.

Experience in the Eli Whitney forest has shown that only about I 5 per cent of the plantations, made on open old-fields, will need a cutting to remove undesirable overtopping vegetation, and not over half of the areas so treated will need a second cutting of the same character. This stands in contrast to the situation where conifers are planted on cutover hardwood areas. There three to four cuttings are usually needed on every area to permanently release the planted conifers from their hardwood competitors. The expense of these cuttings is a strong argument against planting conifers on areas stocked with hardwoods and attempting conversion to conifers.

\section{Artificial Pruning of Branches ${ }^{20}$}

It is now well recognized that production of timber free of knots cannot be secured in stands of pine and spruce, in crops which are allowed to grow only 60 to 80 years, unless the trees are artificially pruned. This fact applies not only to planted stands of these species but also to natural forests of pine and spruce. With the market existing for material of small size, such as can be readily grown within a period of 60 to 80

20. In preparing the section on pruning, information contained in Artificial pruning in coniferous plantations, Yale University, School of Forestry Bul. 39, 1935, has been freely used. 
years, it is probable that second-growth pine and spruce will be harvested when between 40 and 80 years of age.

Plantation-grown timber is likely to be more knotty, at least so far as size of knots in the lower log is concerned, than well-stocked natural stands since not more than 700 to I,200 trees per acre will be planted, giving a relatively open stand for the first I 5 to 20 years. Size of knots in upper logs in second-growth stands will depend more on management policy as regards thinning practice than it will on the question of natural versus artificial origin.

Artificial pruning is a question which merits consideration in the management both of natural and planted stands of pine and spruce, although this discussion refers particularly to planted stands.

It is an expensive operation and its justification must rest on the premise that timber free of knots will be worth enough more in the future as to more than offset the cost of the work. Is this a sound premise? The answer may depend on the species considered since the type of product for which the tree is used is of importance in this connection. Spruce, for example, is used in many regions principally for pulpwood for which product the degree of knottiness characteristic of second-growth stands would not be a serious drawback. Spruce stands form a dense shade and are characterized by the dying of shaded limbs while still small in size. It is doubtful if limbs larger than 1.5 inches in diameter will be found in butt logs of properly stocked Norway spruce plantations, and the great majority will be less than one inch in diameter (see Table 8). However, in southern Connecticut the distance to mills buying pulpwood is too great to make pulpwood a profitable product, at least in the market today. Spruce here finds its principal local market as building dimension. A reasonable amount of knots of such size as may be found in plantationgrown lumber will not prevent the acceptance locally of this lumber for dimension. Spruce also is used for purposes requiring freedom from knots and such material should sell for enough more than knotty dimension to more than cover the cost of pruning. For these reasons the advisability of pruning Norway spruce (and also white spruce) in southern Connecticut will depend largely upon the product for which the tree is grown.

In the case of white pine the probability is greater than for spruce that artificial pruning may prove a profitable investment. White pine has been used for decades for many purposes calling for material clear of knots. Its texture and qualities of workability establish white pine as the best softwood for such use as sash and blind stock, pattern stock, and 
similar special uses. White pine, because of its high technical qualities, will always be worth too much in a region like southern Connecticut to be utilized primarily for pulpwood, even if a market for such material should develop. Clear white pine lumber sells today at a price sufficiently above the price of knotty lumber to cover the expense of pruning. Whether this price differential will prevail several decades hence when trees pruned today are ready for harvest cannot now be known. Each owner will have to decide for himself whether to invest in pruning on the assumption that the present relative scale of prices will hold in the future. The authors believe it likely that market conditions in this region will continue to make clear white pine lumber worth much more than knotty material, and consequently advise artificial pruning of white pine.

Whether the returns from artificial pruning of red pine will justify the investment is more open to question than in the case of white pine, although there appears to be no reason why the same principle should not apply. Red pine for many years in the past was sold as white pine, but at the present time the better grades of red pine lumber are sold on their own merits since the wood possesses somewhat different characteristics. Furthermore artificial pruning costs less for red than for white pine. It may be questioned, however, whether red pine will not find its most general use as structural material and as piling. Pruning would not be justified if piling will be the product grown. With the 8 by 8 foot spacing now advised in planting red pine, many of the lower limbs will be relatively large. Even where structural material is the main product to be grown it may prove profitable to prune the butt log of red pine trees in these wide-spaced plantations. While red pine planting has been discontinued on the Eli Whitney forest, for the reason already mentioned, selected trees in the older plantations which appear reasonably safe from the European shoot moth have been pruned.

Correct plantation pruning is based on pruning only a selection of the best trees adequate in number to fully stock the area when the timber is ready to be harvested. The expense of pruning trees which will be crowded out and die, or have to be cut, before producing enough clear lumber to justify the cost is thus avoided. The final crop produced in well-managed plantations on a 60- to 80 -year rotation is likely to consist, for white and red pines of 60 to 100 trees per acre, and for Norway spruce of 80 to 120 trees per acre. The numbers of trees pruned per acre can well be placed at 20 per cent higher than the number of trees desired in the final crop, to 
allow for poor original selections and for injuries to some of the final crop trees.

The productive capacity of the site, and the character of the prociuct desired, which should govern the type of treatment given the stand, influences the number of final crop trees. In general, the smallest number of final crop trees is likely to be wanted on the most productive and on the poorest sites and the largest number on medium sites. If the product desired may contain fast-grown wood and require pieces of large diameter, a relatively small number of final crop trees is indicated. If wood of relatively slow diameter growth and stems with very little taper are wanted, the number per acre of final crop trees should be relatively large.

The trees selected for pruning should be distributed over the area as evenly as is consistent with selection of the best individuals. These trees ordinarily should be in the dominant or codominant crown classes. The expense of pruning an intermediate or overtopped tree cannot be justified, unless such treatment is promptly given these trees as will place and keep them in a free position, where they will be stimulated to increased growth. Fast growth after pruning is an essential requirement for pruned trees, if cost of the work is to be repaid.

Pruning becomes more expensive as distance from the ground increases. Just how high above the ground artificial pruning can be done and still result in financial profit is difficult to determine. Practice at present is to prune the limbs only from the first I7 feet of the trunk, making it possible to cut a 16 -foot log from the pruned section of the tree. A large proportion of the total tree volume will be found in this pruned butt log.

Success in artificial pruning depends upon developing a zone of wood free of knots and of sufficient width so that square-edged lumber can be sawed out (see Plate 20). The center of each pruned log contains a knotty core around which a zone of clear wood has developed since the pruning. In sawing, the knotty core must be kept separate from the clear lumber. The zone of clear wood should be at least four inches wide and preferably over six inches wide, in order to obtain satisfactory width in the boards. containing clear lumber. Hence artificial pruning is not worth while and should never be undertaken unless the trees will be allowed to grow long enough after pruning to produce the necessary wide zone of clear wood. The diameter of the tree before pruning is less important than the period of time after pruning which will elapse before the tree is harvested. At least a 30 -year period after pruning should be allowed with planted white 
pine and 50 years is desirable. In order to obtain even the smallest adequate zone of clear wood in 30 years after pruning, an annual growth in diameter of at least 0.3 inch must be maintained at the top of the pruned log length. This can be accomplished if the stand is properly thinned.

A variety of methods for carrying on pruning have been tried out and no one method appears to be the best for all conditions. The following procedure for pruning white pine is frequently used in the Eli Whitney forest.

Pruning is begun as soon as all the limbs below 7 feet can safely be removed. This occurs usually around the twelfth to fifteenth year after planting (see Plate I5). The correct time is judged by the degree of closure between adjoining trees (see Figures 2 and 3 ). When branches of adjoining trees interlace those below the highest point of contact may be cut off without decreasing the growth of the tree. Removal of limbs above this point usually results in decrease of growth. Most, though not all, of the branches below this point will be dead. The principle involved is that branches below the point of closure are cut off from the sunlight and hence cannot function efficiently in elaborating plant food. Hence, such branches even though remaining alive for a year or two cannot assist in the growth of the tree and are no longer needed.

Should branches above the point of closure be removed, the growth of the tree both in diameter and in height is likely to be decreased. An exception to this rule of pruning only below point of closure is found in the case of isolated trees. These, if big enough for pruning, will be 15 to 25 feet high, and be standing in an open part of the stand where closure has not taken place and the live crown extends down to the ground. In such cases the removal of the lower 25 per cent of the live crown, measured vertically, can be undertaken without seriously reducing the growth of the trees.

In closed stands pruned first to 7 feet, a second pruning can be made in 3 to 4 years removing the branches from 7 to 12 feet above the ground. Again the same rule is observed of cutting only limbs below the point of closure between adjacent trees. Finally, 3 to 4 years after the second operation, a third pruning is made cutting the limbs between 12 and $I 7$ feet, which latter point should not be below the point of closure. According to this schedule the first pruning probably would come 12 to 15 years after planting, the second 3 to 4 years later, and the third 3 to 4 years after the second. The average stand would be completely pruned 20 years after planting. 
The advantage of making the pruning in three operations instead of one is that in this way the knotty core at the center of the log will be restricted to a smaller diameter than would be the case if all pruning was delayed until the time arrived that the entire 17 -foot length could be pruned at one operation. Such delay may make a difference of as much as two inches in diameter of the knotty core. Carrying on the pruning in three operations rather than in one does not involve extra cost, since there is an adequate volume of work in each operation and the equipment used differs somewhat in each of the three prunings.

The first pruning from the ground to 7 feet is accomplished by a man standing on the ground and equipped with a curved orchard saw. A saw similar to Disston No. 53, which has approximately 8 teeth per inch, cuts chiefly on the pull stroke, has a pistol grip and a blade length of I 2 inches, or a similar type of saw is liked in the Eli Whitney forest. Saws used in pruning should be frequently sharpened and should be washed with kerosene often enough to remove deposits of pitch. The second pruning from 7 to 12 feet is done by a man with the same saw standing on an 8-to 9-foot ladder (see Plate I8). This ladder may be built with a narrow top and fitted with a metal top rung concave toward the tree to fit the trunk. The top rung should be covered with rubber or cloth to prevent wounding of the tree. The third pruning from I 2 to 17 feet is done by a man with a saw working on a longer ladder 12 to I 4 feet in length, similarly equipped (see Plate I6).

Pruning in three operations has a definite disadvantage as contrasted with pruning the full 17 -foot log length in two operations. It is difficult and sometimes impossible to make the right selections of final crop trees so early (twelfth year) at the time of the first pruning operation. Trees which look promising at that time may receive some injury or simply be outgrown by neighboring trees in the next 6 to 8 years. Particularly in stands of white pine where severe attack by the white pine weevil is expected, it may be advisable to delay pruning until the trees have reached a total height of about 20 feet. Pruning is then carried up as high as the point of contact between crowns and finished later on in a second operation (see Plate I7). Individuals which have not been weeviled in the first log can in this method be selected with certainty for pruning, thus insuring butt logs without weevil injury. Weeviling higher up the stem is of less importance than similar injury in the butt log.

Some people prefer saws mounted on poles of different lengths for pruning the section of the log which is above 7 feet. For plantation- 
grown white pine it is believed that the saw and ladder method results in a better and cheaper job than is secured with pole saws. Others favor pruning shears instead of a hand saw for removing the limbs from the ground to 7 feet. The authors believe the saw to be the superior tool in the hands of the average workman for this pruning height.

It stands to reason that all cuts through limbs should be as close as possible to the tree trunk and tangential to it. The longer the stub which is left, the longer will be the time required after pruning before production of clear wood is started. Even where branches are carefully cut flush with the bark it is likely to take several years to heal over the stub (see Plate I9). In the process of healing pitch may accumulate on the branch stub and pieces of bark may be caught under the folds of callus as they grow over the stub (see Plate 2I). To be conservative, an inch should be allowed over every stub for pockets of bark and pitch before clear wood forms across the stub. The diameter of the knotty core, measured at any point on the tree immediately after pruning, should therefore be increased by two inches to allow for the layer containing bark and pitch pockets.

\section{Cost of Pruning and Financial Return Expected}

It is more expensive to prune white pine than red pine, while Norway spruce occupies a middle position. Hours per tree to prune 17 feet are estimated $^{21}$ at 0.225 for white pine, 0.185 for Norway spruce, and 0.146 for red pine. Differences in cost are due to number and size of branches characteristic of the three species.

As an indication of expected returns from pruning Table i 2 has been prepared.2r

Under the conditions stated, the cost of pruning one tree to 17 feet is, at the end of a 60-year rotation, 42 cents for white pine and 31 cents for red pine.

Assuming that a I6-foot log is cut from the 17 -foot pruned length, and that the diameter inside bark at the small end is 16 inches when the tree is felled at 60 years of age, the volume of the log by the International log rule, $1 / 4$-inch kerf, will be 180 feet, board measure. The pruning cost for

2I. The basic data have been taken from Artificial pruning in coniferous plantations, by Ralph C. Hawley and Robert T. Clapp, Yale University, School of Forestry, Bul. 39, 34-36, I935, but have been computed at 3 per cent interest rate instead of 4 per cent used originally in the bulletin. 


\section{CULTURAL OPERATIONS TO INCREASE CROP}

TABLE I2. COST OF PRUNING ONE I7-FOOT LOG OF WHITE OR RED PINE IN THREE OPERATIONS. (USING THE LADDER METHOD FOR HIGH PRUNING.) THE THREE PRUNING OPERATIONS OCCUR IN THE TWELFTH, FIFTEENTH, AND EIGHTEENTH YEARS AFTER PLANTING. COMPOUNDED TO

THE END OF A 6O-YEAR ROTATION AT 3 PER CENT, WITH LABOR AT 50 CENTS PER HOUR

\begin{tabular}{|c|c|c|c|c|c|}
\hline \multirow[b]{2}{*}{ Operation } & \multirow{2}{*}{$\begin{array}{c}\text { Interest com- } \\
\text { pounded for } \\
\text { years }\end{array}$} & \multicolumn{2}{|c|}{ Wbite pine } & \multicolumn{2}{|c|}{ Red pine } \\
\hline & & $\begin{array}{c}\text { Initial } \\
\text { cost }\end{array}$ & $\begin{array}{c}\text { Cost } \\
\text { compounded }\end{array}$ & $\begin{array}{c}\text { Initial } \\
\text { cost }\end{array}$ & $\begin{array}{c}\text { Cost } \\
\text { compounded }\end{array}$ \\
\hline o to 7 feet & 48 & $\$ .0370$ & $\$ .1529$ & $\$ .0305$ & $\$ .1260$ \\
\hline 7 to 12 feet & 45 & .0265 & .1002 & .0205 & .0775 \\
\hline I 2 to 17 feet & $4^{2}$ & .0475 & .1644 & .0320 & .1107 \\
\hline Whole log & & $\$ .1110$ & $\$ .4175$ & $\$ .0830$ & $\$ .3142$ \\
\hline
\end{tabular}

white pine will be 42 cents for I 80 board feet or $\$ 2.33$ per thousand feet, board measure, and for red pine 3I cents for I 80 board feet or $\$ I .72$ per thousand feet, board measure.

With a given cost of pruning, the profit depends upon the amount of clear lumber sawed from a log and the prices of clear and knotty lumber. Logs with an appreciable width of clear wood in the outer zone are sawed around, rather than through and through, so as to get the maximum number of board feet of clear lumber. Sawed in this manner a log 16 inches in diameter at the small end, with a 6-inch central knotty core, will saw out at least 75 per cent clear boards and not more than 25 per cent knotty. ${ }^{22}$

On this basis and using the prices of $\$ 50$ per thousand feet, board measure, for clear white pine lumber and $\$ 25$ for knotty lumber ${ }^{23}$ the value of white pine butt logs, if unpruned, would be at the rate of $\$ 25$ per thousand feet, board measure, and, if pruned, at the rate of $\$ 43.75$. This shows a difference in favor of the pruned logs of $\$ 8.75$ per thousand feet, board measure. Subtracting the pruning cost of $\$ 2.33$ per thousand, the profit from pruning white pine butt logs is found to be $\$ 16.42$ per thousand feet, board measure. Pruning red pine and spruce cannot be expected to show as large a profit as is indicated for white pine, but the operation should prove profitable for all these species.

22. This estimate is based upon the diagraming of the small end of the $\log$ to show the number and width of clear and knotty I-inch boards when properly sawed with a saw cutting a $1 / 4$-inch kerf. To be conservative, short clear boards which might be sawed from the butt end of the log were not included.

23. These prices are considered conservative over a long period of time such as a crop rotation, ignoring temporary fluctuations. 
One could arrive at almost any figure of profit, or even loss, by using different combinations of values for the factors involved in pruning, which may be listed as follows: Age of stand when pruned, growth rate of trees after pruning, length of rotation, speed of pruning, wage rate, interest rate, and value of clear and knotty lumber. Since experience as to results is so limited, all that can be attempted in the way of estimating the financial results of pruning is to set forth reasonable and conservative conditions under which pruning can be done at a profit. It is the problem of each individual plantation owner to analyze the factors as they apply to his particular situation and determine for himself whether or not he should practice pruning.

In ending this discussion of pruning a word of caution may not be amiss. For many forest owners and their foremen pruning trees apparently possesses a greater fascination than other lines of work in the forest. Once started they dislike to stop until all the trees on an area have been pruned. One definite consequence is to increase the cost per acre by at least fourfold and thus almost certainly destroy any chance for making a profit on the operation. But this is not the only bad effect of pruning all the trees in a stand. Pruning on such a wholesale scale opens up a young stand too drastically to the sun and wind with the result of increasing evaporation and creating unfavorable atmospheric and soil conditions. Trees along the edge of the forest, where it adjoins open areas, should never be pruned but should be allowed to retain their branches to the ground in order to form a wind and sun mantle on the edge of the forest (see Plate 4 ). For best growth a forest should have a calm interior, free from wind movement and from the drying effects of too much sun.

\section{Thinning}

The fact has previously been emphasized that the trees in a forest compete continually with one another and thereby are mutually weakened. By periodically reducing the number of trees on an area, competition of an intensity sufficient to reduce the grow th rate of the better trees can be avoided. In fact, by skillfully regulating the number of competing trees, the growth rate of the better trees can be controlled to meet the purposes of management. The amount of moisture and food materials available for tree growth on any given area is relatively fixed and limited, but the amount available for a single tree can be increased by reducing the number of trees thereby concentrating the moisture and food supplies 
upon the growth of the remaining trees. Since a group of relatively few trees of large diameter on an area will yield a much higher amount of lumber than numerous trees of small diameter, the advantage of concentrating growth on a small number of trees is evident.

The term applied to cuttings made for this purpose is thinning. Thinning, in contrast to the removal of overtopping plants, strikes mainly at the trees offering side competition and often removes individuals of the same, or of as good, species as the trees left standing. In other words, thinning does not have as its primary purpose a change in the species composition of the stand, but rather attempts to maintain or increase the rate of growth of the best individuals.

The live-crown ratio is one of the best criteria for judging whether a stand is in need of a thinning. If this ratio, as estimated on the dominant and codominant trees in the stand, has dropped to less than 35 per cent of the total height then a thinning is needed at once. The objective should be to maintain a live-crown ratio on the final crop trees of 35 to 40 per cent in white and red pine stands and 40 to 50 per cent in Norway spruce stands.

Thinning, not being primarily designed to change composition, is less critical a type of operation than release from overtopping trees and consequently can usually be delayed in a young stand until the trees to be removed have reached salable size. In plantation management the original spacing should be so chosen as to allow proper development of the planted trees without excessive competition with one another, up to such age and size as will make a first thinning possible without direct expense. As a general rule thinning in a young plantation is delayed until the financial return from the trees to be cut at least equals the expense of making the thinning. Like all rules this one has exceptions.

Unfortunately pine and spruce trees too small to cut into dimension lumber have practically no sale value in southern Connecticut. A much better grade of fuelwood, as well as post material, is furnished abundantly from native hardwoods which crowd the softwoods out of these markets. The minimum-sized salable pine or spruce $\log$ is one with a 6-inch top and 8 feet long (see Plate 3 ). Trees containing only material of smaller size cannot be disposed of except in a small way. Thus in conifer plantations an early thinning which can take out only trees below merchantable log size usually fails to pay expenses.

In white pine plantations in the Eli Whitney forest, made with a spacing of 6 by 6 feet, the first thinning can be made to pay its way at 


\section{CONIFER PLANTATIONS IN THE ELI WHITNEY FOREST}

about the twenty-fifth year after date of planting (see Plates 22 and 23). From that time on thinnings should be made at approximately five-year intervals, until the time comes to harvest the final timber crop. Each subsequent thinning should be increasingly profitable, and the total net returns from the thinnings may form a quarter to a third of the total. net returns from growing the crop.

There are several methods of making thinnings but under a given set of conditions one is likely to be the best. In conifer plantations which have been pruned, the character of thinnings needed is determined by the pruning operation (see Plate 5). A relatively large investment has been made in pruning 75 or more trees per acre, selected as final crop trees, most of which will be carried on to the time of harvesting the crop. If everything works out as planned, only pruned trees will be left at the time of final harvest and will fully stock the area. All unpruned trees will have been removed earlier in the several thinnings.

Selection of trees to be cut in thinnings centers around the pruned trees. Unless these trees are kept growing at the rate of at least one inch in diameter every three years the expense of pruning may never be repaid. This diameter growth rate will not be maintained in unthinned stands of white and red pines or Norway spruce originally spaced 6 by 6 feet. Hence, it is vital that thinnings to stimulate growth of pruned trees be started early and repeated at intervals of about five years. Sometimes, in particularly dense stands, it may be necessary to make the first thinning before the material removed will pay expenses of the operation in order to maintain the desired diameter growth rate on the pruned trees.

At each thinning those trees which offer the greatest competition with pruned individuals are removed. They are the trees which are pressing with their crowns most closely against the pruned trees. The trees cut are principally in the codominant class with some in the dominant and occasionally in the intermediate classes. No attempt is made in any one thinning to entirely eliminate competition with pruned trees, as it would involve too radical a cutting. It is best to restrict the size of an individual opening made in any one thinning to that created by the removal of a single tree. Enlargement of the opening by removing one or more adjoining trees should be avoided to prevent drying of the soil and sunscald, windthrow, or breakage of the pruned trees.

As yet the plantations are not old enough to have received many thinnings, and in fact most of the plantations are too young to have been thinned even for the first time. Hence adequate experience as to the 
number of trees and volume removed at successive thinnings has not been acquired. A few examples of specific thinnings may be of interest. One stand of white pine ${ }^{24}$ thinned when 23 years of age yielded approximately I,100 feet, board measure, per acre, in the removal of about 100 trees per acre, over an area of I6 acres (see Plate 22). In another case a white pine plantation was first thinned in its fifteenth year, removing I 8 of the largest unpruned trees per acre. The material cut was all of cordwood size. A second thinning of the same type was made five years later, removing 32 trees per acre, mostly cordwood size. A third thinning was made in the twenty-sixth year, removing from among the largest unpruned individuals 67 trees per acre, which yielded I,500 board feet of square-edged lumber. These three thinnings, although each as heavy as was silviculturally desirable at the time it was made, have not completely freed all the pruned crop trees from crowding.

Another white pine plantation was first thinned when 20 years old, taking out 60 of the smaller trees per acre for oyster buoys. A temporary market for this product made the first thinning financially profitable. Nine years later a second thinning removed 80 trees per acre, taking out the individuals most seriously crowding the pruned crop trees. The yield in this thinning amounted to I,600 board feet per acre.

A red pine plantation was first thinned at the twentieth year. There were approximately I, I00 trees per acre at that time, of which I 50 of the largest unpruned trees were cut. Only material of cordwood size was obtained. Five years later a second thinning of similar character was made, taking out $9^{8}$ trees per acre (see Plate 9). Even after this thinning all the final crop trees had not been fully relieved of severe competition from unpruned individuals. The second thinning yielded I, IOO board feet per acre.

Red pine plantations, with an original spacing of 6 by 6 feet, need thinning around the fifteenth to twentieth year after planting. At that time nearly all the trees which should be cut in a first thinning are less than 6 inches in diameter at breast height. No reliable market has yet been found for red pine material of this size. Hence, the first thinning, if made at all, will require a direct expenditure. This fact led, as already stated, to a change from 6 by 6 to 8 by 8 foot spacing. Plantations made with this latter spacing should not require thinning until the trees to be

24. First thinning in white pine plantations, by R. T. Clapp. Journal of Forestry 34: 928-935, 1936. 
removed are large enough to be put into 2 by 4 inch dimension or into inch boards. The method of thinning red pine plantations has been the same as in white pine, since the older red pine plantations contain pruned crop trees which need release.

Norway spruce plantations established with 6 by 6 foot spacing, because of the shade-enduring habit of this species and its ability to express early differentiation into crown classes, will not require thinning before the thirtieth to thirty-fifth year, at which time the first thinning should at least pay expenses, and give a profit where pulpwood can be sold. From this time on thinnings should be repeated as often as needed to maintain the desired growth rate of the final crop trees. The material from the second and subsequent thinnings should be of sizes suitable for lumber.

Plate 24 shows a 30 -year-old Norway spruce stand where a profitable thinning for oyster buoys has recently been made. Plate 25 illustrates a profitable first thinning in a 35 -year-old red oak stand established by direct seeding.

\section{HARVEST OF THE MATURE TIMBER WITH PROVISION FOR ESTABLISHING A NEW CROP}

7 HIS last stage in producing timber crops is still in the future so far 1 as the local conifer plantations are concerned. Only a small percentage of the plantations has passed the 3o-year mark. It has already been indicated that satisfactory yields of timber should be secured from stands 50 years in age or older. Where artificial pruning is practiced harvesting of the pruned trees should not come before the sixtieth year. How much longer than 60 years the crop should be allowed to grow will depend upon conditions in each plantation and upon the desires of the owner.

On page 34 the probable course of development in older plantations was discussed and the point emphasized, that a crop of hardwood seedlings may be counted upon to establish themselves naturally under the planted conifers. The repeated thinnings which have been advised will favor and hasten this natural process of conversion to a hardwood type. Pine and spruce seedlings will also be encouraged by the thinnings and will undoubtedly appear with the hardwoods. In fact pine seedlings already have appeared in some 30 -year-old stands, which have been 
opened up by thinnings. If desired, pine seedlings can be favored by releasing them from overtopping hardwoods. In this way a mixture of pine and spruce can be secured and maintained with the new crop of hardwoods. Without release most of the pine and spruce seedlings, which may appear, will be outgrown and eventually eliminated by their hardwood competitors. It is too early to predict the extent to which it will be desirable to favor pine and spruce in the second crop. This is a subject for future consideration and does not require immediate decision. What is plainly seen is that natural regeneration of hardwoods will be abundantly present in the conifer plantations before they are ready to harvest, and that if any appreciable amount of pine or spruce is wanted in the succeeding crop special treatment will be required.

\section{ESTIMATED COSTS AND RETURNS OF GROWING PLANTED WHITE PINE AND NORWAY SPRUCE}

TN Table $\mathrm{I}_{3}$ an estimate of the cost of establishing and caring for 1 plantations of eastern white pine is given, and in Table $\mathrm{r}_{4}$ estimated financial returns from these plantations are shown.

It will be seen that plantations of white pine may be expected to yield considerably better than a 3 per cent compound interest return. Admittedly the figures both of costs and returns are purely tentative estimates, since no planted stands of white pine in the Eli Whitney forest have yet reached the rotation age (6o years) and very few old plantations exist anywhere in Connecticut. Consequently, the results of past experience are not available. However, many of the operations such as planting, release, pruning, and protection have already been undertaken and illustrations of their costs obtained. Estimates of lumber production have had to be secured from such thinning operations as have been made in the plantations, and from extending into the future the growth rates found in the young plantations (see Figure 6). These data have been supplemented by data on production of a few older plantations in other parts of Connecticut and by knowledge of past production in natural stands of white pine.

It is believed that the items of cost and yield given in the tables are conservative. In order to explain the figures used in Tables $I_{3}$ and $I_{4}$ discussion of the various items included in them is needed.

Cost of planting stock is estimated at the prices listed by the Con- 
necticut State Park and Forest Commission for forest planting stock in the spring of 1943 . These prices are $\$ 12.00$ for white pine 3-year-old transplants. With a 6 by 6 foot spacing approximately $\mathrm{r}, 200$ trees are required per acre. Including the cost of transportation, planting the trees, and an allowance of 5 per cent for refilling blanks in the plantations the total cost of establishing a white pine plantation is estimated at $\$ 28.77$ per acre. This should be an ample allowance and greatly exceeds the amount actually spent in establishing the plantations which have been made in the Eli Whitney forest.

As young plantations develop, some release from overtopping hardwood may be necessary as explained earlier. On the bare or sod-covered old-fields, which are the type of site recommended for planting, release will be needed over only a small portion of the area. It is estimated that I 5 per cent of the area will require one release and 7.5 per cent a second release. The cost (one day's work for each acre actually worked on) is spread over the entire plantation. The expense of artificial pruning of the branches up to I7 feet above the ground has been included for selected trees (IOO per acre for white pine). This requires an outlay of $\$ 1$ I.IO per acre.

Protection must be provided of course against forest fires which may quickly destroy plantations, particularly in the early years before a complete forest cover has been established. While forest fire protection in southern Connecticut is furnished by the State Forestry Department, an allowance of 4 cents per acre per year, to cover work which the owner himself might undertake, has been entered as an expense item against the plantations.

White pine requires protection also against blister rust and the white pine weevil. An annual charge of 6 cents per acre per year for blister rust, and 50 cents per acre annually for weevil control during a ro-year period (fourth to thirteenth years inclusive), is the estimated cost for effectively controlling these pests.

An annual charge of 50 cents per acre is allowed for general supervision. Taxes are exceedingly difficult to estimate but are likely to be one of the largest items of cost in forest crop growing. In the present estimate $\$ 36.60$ has been allowed for taxes which is an average annual charge of 6I cents per acre.

All these expenses incurred at various times during the life of the forest crop amount to a total cash expenditure of $\$ 118.37$ per acre. In order to bring the expenditures into direct comparison with the returns, the 


\section{PLANTED WHITE PINE AND NORWAY SPRUCE}

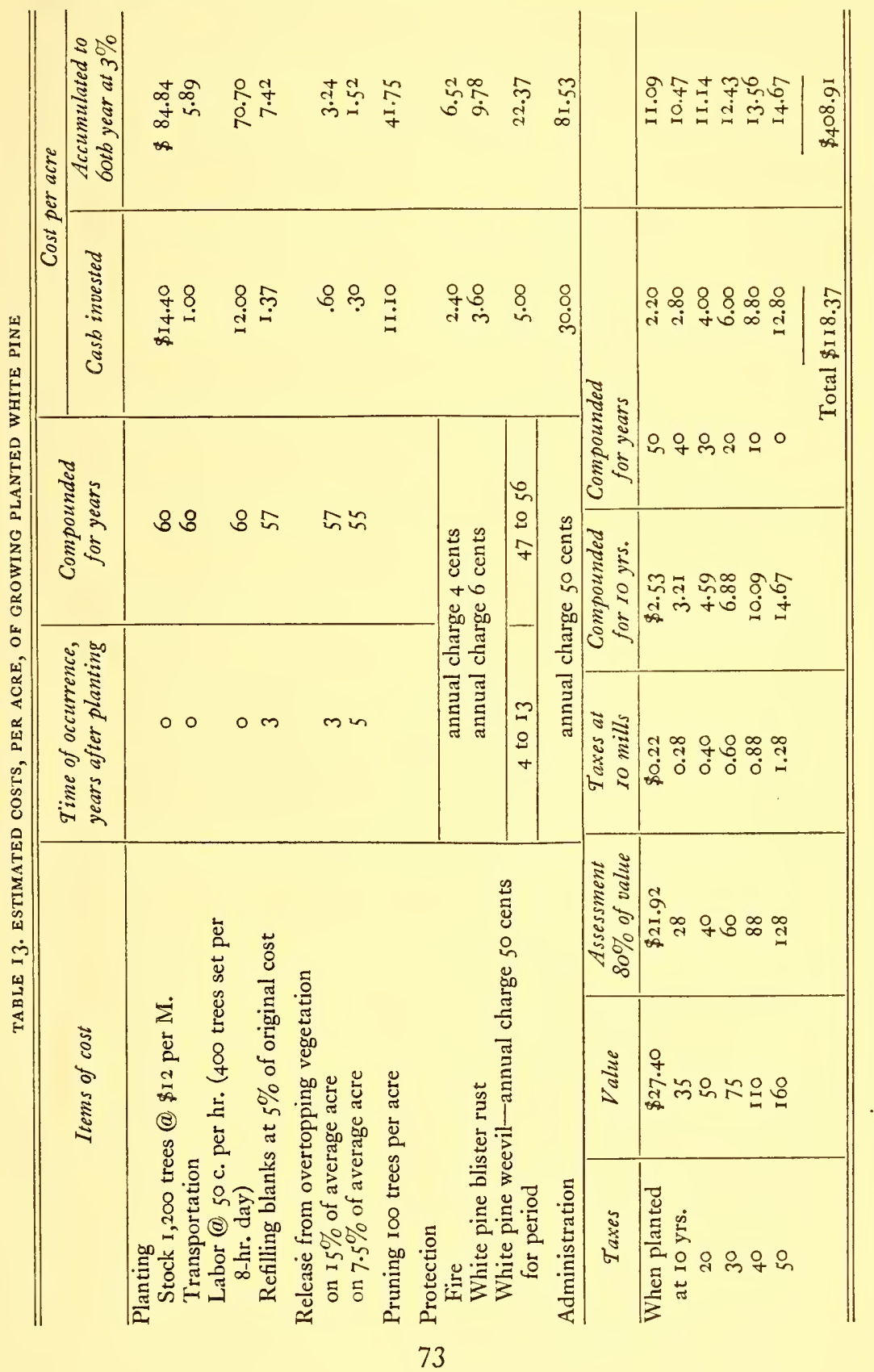




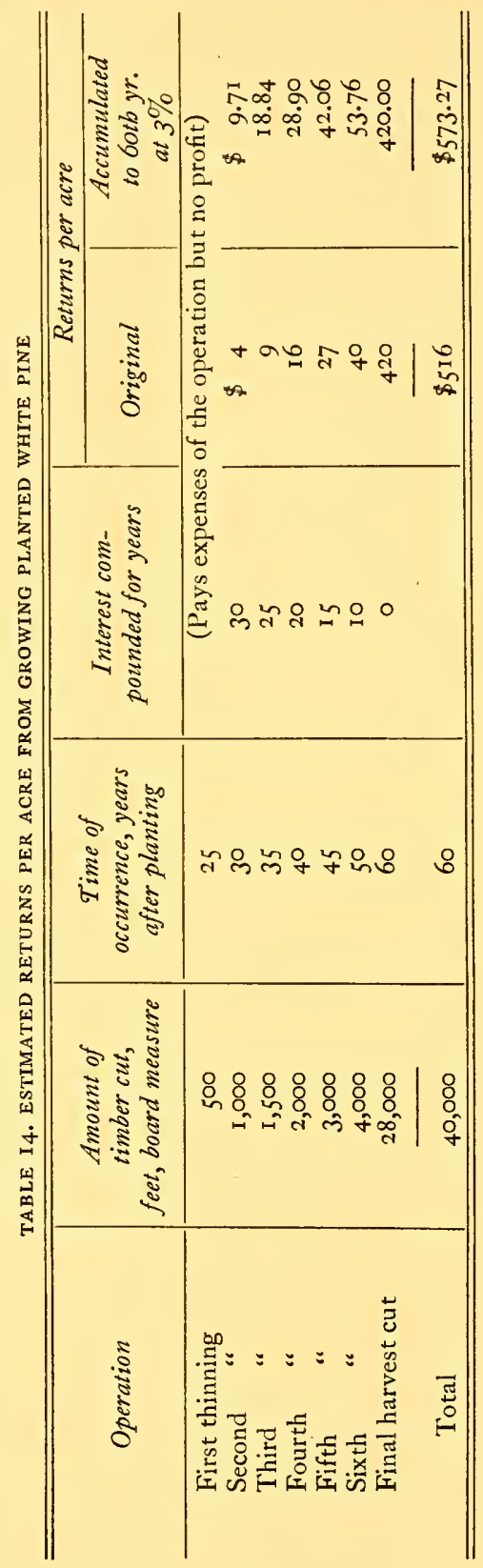


former have been carried forward at 3 per cent compound interest to the time when the mature crop (60 years of age) can be harvested. These accumulated costs amount to $\$ 408.9$ I per acre for white pine plantations.

In contrast to these expenditures estimated receipts from plantations are shown in Table 14. Cash receipts during the 60-year period are estimated at $\$ 516$ per acre. Accumulated at 3 per cent to the end of the rotation they amount to $\$ 573.27$ per acre.

It should be emphasized that Table I4 applies only to well-stocked and properly managed stands of white pine in southern Connecticut established on soils average or better in quality. On dry, shallow, sandy, or otherwise poor soils and in partially stocked, ill-managed stands similar results will not be secured.

Nothing has been said as yet regarding expense of growing and expected returns from crops of Norway spruce, the species which in addition to white pine is recommended for planting. Actual experience with this species in Connecticut is more meagre than in the case of white pine. Furthermore, Norway spruce is an exotic species, and hence comparison of plantations with yields from naturally reproduced stands cannot be made.

However, Norway spruce has the reputation, both in this country and in Europe, its native home, of producing exceptionally high yields of timber and in fact is considered one of the best conifers in this respect. The species has been planted to greater extent in New York State and in the other New England states than in Connecticut. A few mature plantations do exist in the northeastern United States. Hosley ${ }^{25}$ made a study of Norway spruce in this region based on inspection of many plantations, although only one of these was located in Connecticut and that on a poor sandy soil on which spruce should not be planted. His investigation makes available in one reference considerable information on the habits of Norway spruce and its probable success in plantations.

Hosley's (p. 23) conclusion in reference to volume production of Norway spruce plantations is as follows: "Certainly one of its most striking characteristics in America is the high yield which has been produced in the older plantations on better sites. The few plantations in the Northeast that have reached ages from 35 to 65 years show far higher yields than any other species, native or exotic, grown here to date."

25. Norway spruce in the Northeastern United States, by N. W. Hosley. Harvard Forest, Bul. Io. 1936. 
Since indications from younger plantations in the Eli Whitney forest point the same way, it appears conservative to estimate that timber production in Norway spruce plantations will equal that in white pine plantations. Probably the times for thinnings and the amounts per acre removed in the thinnings will not be the same for the two species. Very likely prices may not be quite as high for plantation-grown spruce as for white pine lumber but this is uncertain. Expenses of growing Norway spruce plantations should be slightly less than for white pine. For the former species no expenditure for protection against white pine blister rust is required, very little if any against white pine weevil, and pruning is cheaper. On the other hand, 4-year-old transplants of Norway spruce should be used in planting in contrast to 3-year-old stock of white pine. Thus, cost of planting is somewhat higher for spruce.

In conclusion it appears reasonable to expect that Norway spruce plantations grown for timber will furnish at least a 3 per cent compound interest investment in southern Connecticut.

A source of income, other than from timber, which can be developed in southern Connecticut from spruce plantations is the production of Christmas trees. These might form the principal product, the stand being harvested when 10 to 20 years old and a new plantation established. In many cases it will be preferable to cut Christmas trees only out of the tops of individuals removed in thinning operations and to carry selected trees on to timber size. Sale for Christmas trees should make even the earliest thinnings in spruce stands financially profitable.

The first plan may prove more profitable than growing timber on a relatively long rotation such as 60 years. Success hinges for one thing upon having available a market for the Christmas trees. At present there is a greater demand for native-grown Christmas trees than can be supplied. Freshly cut native-grown trees sell more readily than those shipped in from a distance and are capable of replacing the latter. Details of managing spruce for Christmas trees in southern Connecticut have not as yet been worked out. Plantations might well be made at a spacing of 4 by 4 feet with the expectation of cutting out part of the trees in a first thinning about 8 years after planting. 


\section{CONCLUSIONS}

D URING the last 30 years thousands of acres of formerly cultivated or pastured fields in southern Connecticut have been lying virtually unused. Many of these fields have been planted to conifers, principally white and red pines and Norway spruce, but thousands more still remain without trees. In the course of time such fields gradually seed up with the native hardwoods and thus revert to forest and ultimate forest productivity.

Time can be saved and a larger and more valuable crop of timber obtained by planting these fields with white pine or Norway spruce, which species are easier to establish artificially on grass-covered fields than good timber-producing hardwoods such as ash, basswood, sugar maple, and yellowpoplar. Red oak can be established readily by artificial means (see Plate 25).

Native-grown softwood can be sold locally in competition with southern and western lumber. It is believed that the future for nativegrown lumber should be viewed with optimism rather than the reverse. The density of population in southern Connecticut, its industrial development, and its distance from the larger sources of lumber supply all indicate that the future for native lumber is promising.

Experience has shown that white pine and Norway spruce can be successfully grown in southern Connecticut, but that red pine should not be planted unless some practicable method for control of the European pine shoot moth can be found.

Plantations of all species to be successful must be established with the right kind of stock, suited to the locality, and must receive at all stages of their development proper treatment. Failures in the past can be traced to disregard of this principle, and should not be made the basis for faulty reasoning leading to the viewpoint that it is unwise and impractical to establish forest plantations.

The question has been considered as to whether plantations of pine and spruce in pure stands, in a region like southern Connecticut, where a mixed hardwood forest forms the prevalent natural growth, will injure the soil and also are so unfitted to the site that satisfactory growth cannot be counted upon. This idea stems principally from European experience in planting Norway spruce out of its natural range, on unfavorable sites, and from growing repeated crops on the same ground. Those who have most thoroughly looked into the literature on this sub- 


\section{CONIFER PLANTATIONS IN THE ELI WHITNEY FOREST}

ject are not likely to cite this European case as an argument against the planting of pine and spruce as practiced in southern Connecticut. Planting of conifers here, if desired, may be for one crop only, for as already explained hardwoods will establish naturally a second crop. No serious harm to the soil can accrue from growing one crop of pine or spruce on it for 60 to 80 years, particularly since the thinnings introduce hardwood seedlings in the last 30 years of the crop's life. As a matter of fact, evidence from experience so far indicates that excellent soil conditions can be maintained in plantations and no basis is found for belief that even successive crops of white pine and Norway spruce would adversely affect the soil.

Pure stands are less safe in theory than mixed stands, but here again in actual practice the former may be better and reasonably safe to use in southern Connecticut. White pine in natural regeneration frequently forms pure stands. In fact most of the white pine timber cut in the last Ioo years occurred in pure, evenaged stands. Norway spruce, while an exotic, is thoroughly at home in the climate and on the soils of southern Connecticut. Both these species thrive in pure evenaged stands and produce high yields of timber.

Although there is no necessity to do so, yet it is quite possible to make mixed plantations of two or four species without extra expense, though the amount of timber produced in a given time may be smaller than obtained in the pure pine or spruce stand. Whether the injury actually done to a given species by its dangerous enemies would be lessened by such mixed planting, as compared to pure planting, is very doubtful. What might be anticipated is that, if an enemy attacking one species became very destructive, the plantation would still be partially productive because of the mixture of other species.

In conclusion, it is believed that planting of white pine and Norway spruce (and probably white spruce) will prove profitable and should be continued on old-fields in southern Connecticut, with the definite intention of growing one crop of pine or spruce timber in a 60- to 80-year period, to be followed in the second rotation either by a forest of hardwoods, naturally seeded, or by pine or spruce in varying mixture with hardwoods.

The original plantings may be in pure stands of each species or they may be small groupwise mixtures of pine and spruce and possibly red oak. 


\section{APPENDIX}

\section{APPENDIX}

TABLE I 5. COMMON AND SCIENTIFIC NAMES OF TREES MENTIONED IN TEXT

Common name

Alder, smooth

Alder, speckled

Ash, white

Basswood

Birch, gray

Cherry, black

Dogwood, flowering

Douglas fir

Hemlock, eastern

Larch, eastern

Larch, European

Maple, red

Maple, sugar

Oak, red

Pine, Austrian

Pine, Japanese red

Pine, Mugho

Pine, ponderosa

Pine, red

Pine, Scotch

Pine, white

Redcedar, eastern

Sassafras

Spruce, Norway

Spruce, red

Spruce, white

Whitecedar, northern

Yellowpoplar
Scientific name

Alnus rugosa (Du Roi) Spreng.

Alnus incana (L.) Moench.

Fraxinus americana L.

Tilia americana $\mathrm{L}$.

Betula populifolia Marsh.

Prunus serotina Ehrh.

Cornus florida L.

Pseudotsuga taxifolia (Poir) Britt.

T'suga canadensis (L.) Carr.

Larix laricina (Du Roi) K. Koch.

Larix decidua Mill.

Acer rubrum $\mathrm{L}$.

Acer saccbarum Marsh.

Quercus borealis var. maxima (Marsh.) Ashe.

Pinus nigra Arnold.

Pinus densifiora Sieb. and Zucc.

Pinus mugo var. mugbus Zenari.

Pinus ponderosa Dougl.

Pinus resinosa Ait.

Pinus sylvestris $\mathrm{L}$.

Pinus strobus $\mathrm{L}$.

Funiperus virginiana L. var. crebra Fern.

Sassafras albidum (Nutt.) Nees.

Picea abies (L.) Karst.

Picea rubens Sarg.

Picea glauca (Moench) Voss.

Tbuja occidentalis $\mathrm{L}$.

Liriodendron tulipifera L. 


\section{CONIFER PLANTATIONS IN THE ELI WHITNEY FOREST}

TABLE I6. VOLUME TABLE FOR PLANTATION-GROWN WHITE PINE SHOWING THE MERCHANTABLE CONTENTS OF THE STEM IN BOARD FEET BY THE INTERNATIONAL LOG RULE ( $1 / 4$-INCH SAW KERF), BETWEEN A STUMP HEIGHT OF 0.5 FOOT AND A TOP DIAMETER OF 5.0 INCHES, INSIDE BARK

\begin{tabular}{|c|c|c|c|c|c|c|c|c|c|}
\hline \multirow{3}{*}{$\begin{array}{c}\text { Diameter } \\
\text { breast beigbt, } \\
\text { incbes }\end{array}$} & \multicolumn{8}{|c|}{ Total beigbt in feet } & \multirow{3}{*}{$\begin{array}{c}\text { Basis, } \\
\text { number of } \\
\text { trees }\end{array}$} \\
\hline & 25 & 30 & 35 & 40 & 45 & 50 & 55 & 60 & \\
\hline & \multicolumn{8}{|c|}{ Volume in board feet ${ }^{*}$} & \\
\hline & \multirow{9}{*}{7} & & & & & & \multirow{5}{*}{$\begin{array}{l}36 \\
51 \\
\end{array}$} & \multirow{9}{*}{$\begin{array}{l}75 \\
94\end{array}$} & \\
\hline 6 & & 4 & 7 & 9 & 10 & & & & 166 \\
\hline 7 & & 10 & 12 & I5 & 18 & 21 & & & I74 \\
\hline 8 & & I5 & 19 & 24 & 28 & 32 & & & 166 \\
\hline 9 & & $2 I$ & 27 & 33 & $3^{8}$ & 44 & & & 140 \\
\hline IO & & & \multirow{4}{*}{$\begin{array}{l}35 \\
43\end{array}$} & 43 & 50 & 59 & 67 & & 67 \\
\hline I I & & & & 53 & 63 & 74 & \multirow{3}{*}{$\begin{array}{r}84 \\
102\end{array}$} & & 26 \\
\hline 12 & & & & 65 & 77 & 90 & & & 8 \\
\hline 13 & & & & 77 & $9^{2}$ & & & & \\
\hline $\begin{array}{c}\text { Basis, } \\
\text { number of } \\
\text { trees }\end{array}$ & I & $4 \mathrm{I}$ & 166 & 320 & I97 & 20 & 2 & & 747 \\
\hline
\end{tabular}

*Taken from Volume tables plantation-grown white pine, Pinus strobus, L. in Connecticut, by Henry W. Hicock, Arnold D. Rhodes, and A. Richard Olson. Conn. Agr. Exp. Sta., Bul. 427. I939.

Heavy line indicates extent of original data.

TABLE I7. VOLUME TABLE FOR PLANTATION-GROWN RED PINE SHOWING THE MERCHANTABLE CONTENTS OF THE STEM IN BOARD FEET BY THE INTERNATIONAL LOG RULE (I/4-INCH SAW KERF). CONSTRUCTED BY ARNOLD D. RHODES IN I937 FROM ORIGINAL TAPER DIAGRAMS FORMING BASIS OF VOLUME TABLES ISSUED IN CONN. AGR. EXP. STA., BUL. 4 I 3

\begin{tabular}{|c|c|c|c|c|c|c|c|}
\hline \multirow{3}{*}{$\begin{array}{c}\text { Diameter } \\
\text { breast beigbt, } \\
\text { incbes }\end{array}$} & \multicolumn{6}{|c|}{ Total beigbt in feet } & \multirow{3}{*}{$\begin{array}{c}\text { Basis, } \\
\text { number of } \\
\text { trees }\end{array}$} \\
\hline & 30 & 35 & 40 & 45 & 50 & 55 & \\
\hline & \multicolumn{6}{|c|}{ Volume in board feet ${ }^{*}$} & \\
\hline 6 & 3 & 5 & 7 & 8 & 9 & & 160 \\
\hline 7 & 6 & I0 & I3 & 16 & I 8 & & 65 \\
\hline 8 & & I3 & I9 & 24 & 28 & 32 & 10 \\
\hline 9 & & & 23 & $3 I$ & 39 & 45 & $\mathbf{I}$ \\
\hline $\begin{array}{c}\text { Total number } \\
\text { of trees }\end{array}$ & 36 & I33 & 58 & 6 & 3 & & 236 \\
\hline
\end{tabular}

${ }^{*}$ Heavy line indicates extent of original data. 


\section{APPENDIX}

TABLE I8. TREE HEIGHTS FOR PLANTATION-GROWN WHITE AND RED PINE IN SOUTHERN CONNECTICUT

\begin{tabular}{c|c|c}
\hline \multirow{2}{*}{$\begin{array}{c}\text { Diameter } \\
\text { breast beigbt, } \\
\text { incbes }\end{array}$} & \multicolumn{2}{|c}{ Total beigbt in feet } \\
\cline { 2 - 3 } 2 & Wbite pine & Red pine \\
3 & I5 & 9 \\
4 & 19 & 13 \\
5 & 22 & 21 \\
6 & 25 & 31 \\
7 & 29 & 35 \\
8 & 32 & 38 \\
9 & 35 & 40 \\
I0 & 38 & 42 \\
II & 41 & 43 \\
I2 & 45 & 45 \\
13 & 48 & 47 \\
I4 & & 48 \\
Basis, number & & 50 \\
of trees & 1,534 & 844 \\
\hline
\end{tabular}



ILLUSTRATIONS 


\section{PLATE I}

OLD-FIELD PLANTING SITE STOCKED PRINCIPALLY WITH GRASSES AND CEDARS.

This area has more cedars than the average planting site in the Eli Whitney forest. Cultivation was abandoned several decades ago, but pasturing of cattle was carried on until recently. While a few seedlings of hardwood trees and woody shrubs have started, the area may still be classed as an open planting site. Pine or spruce planted beside the cedars grows faster than the latter and will eventually overtop and kill them. The area was planted to pine one year ago, although the planted trees are hidden in the grass. 


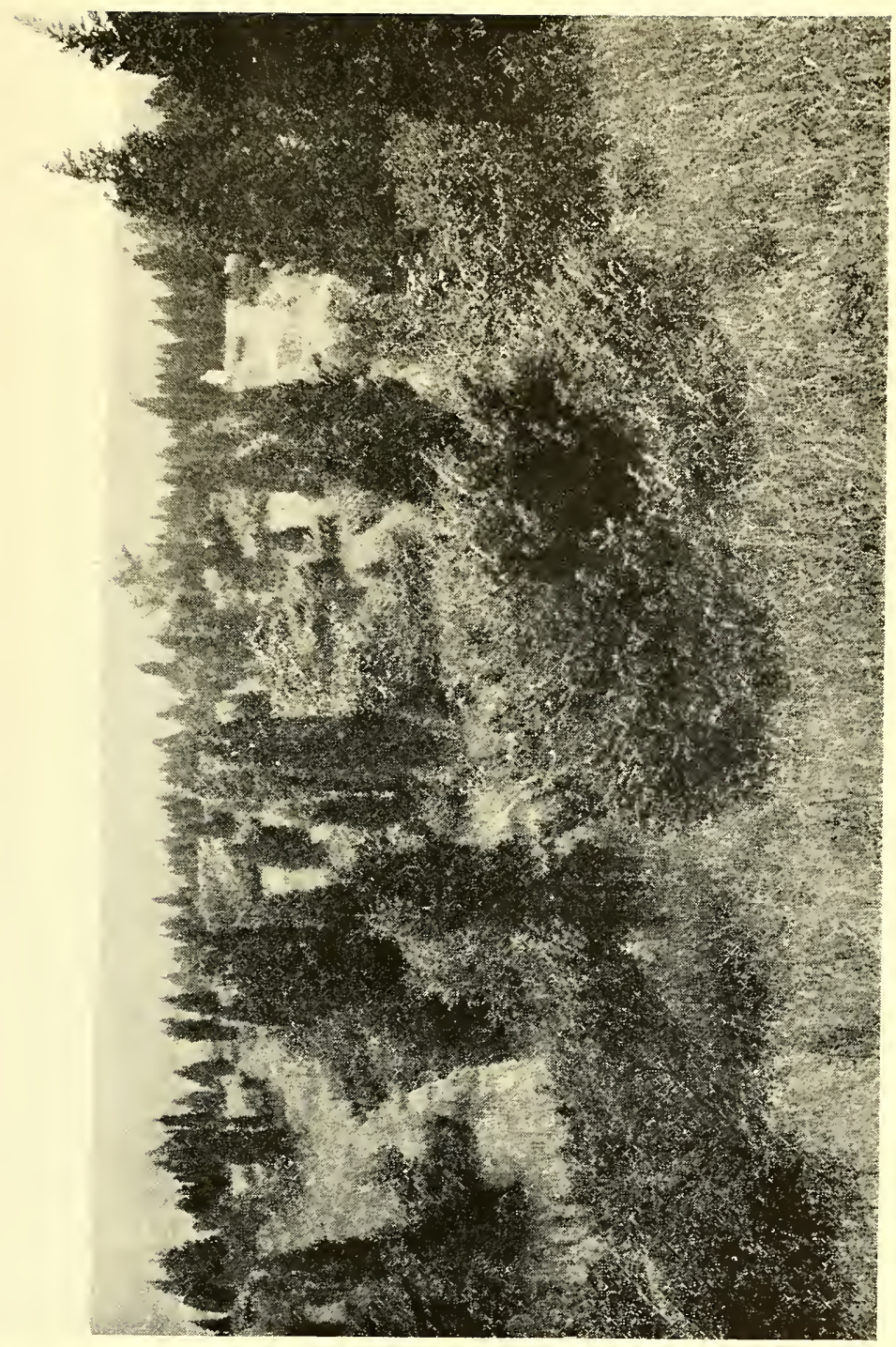




\section{PLATE 2}

WHITE PINE PLANTATION, ESTABLISHED 7 YEARS, WHICH HAS NOT QUITE CLOSED.

At the time of planting, the area was a meadow having good quality soil. The stand has been protected against the white pine weevil by cutting off and burning the infested leaders early each summer. Trees range in height from 6 to 7 feet. A few hardwoods have seeded in among the pine, but as yet no release cutting to free the pine has been necessary. This stand will be ready for the initiation of artificial pruning in less than 5 years. 


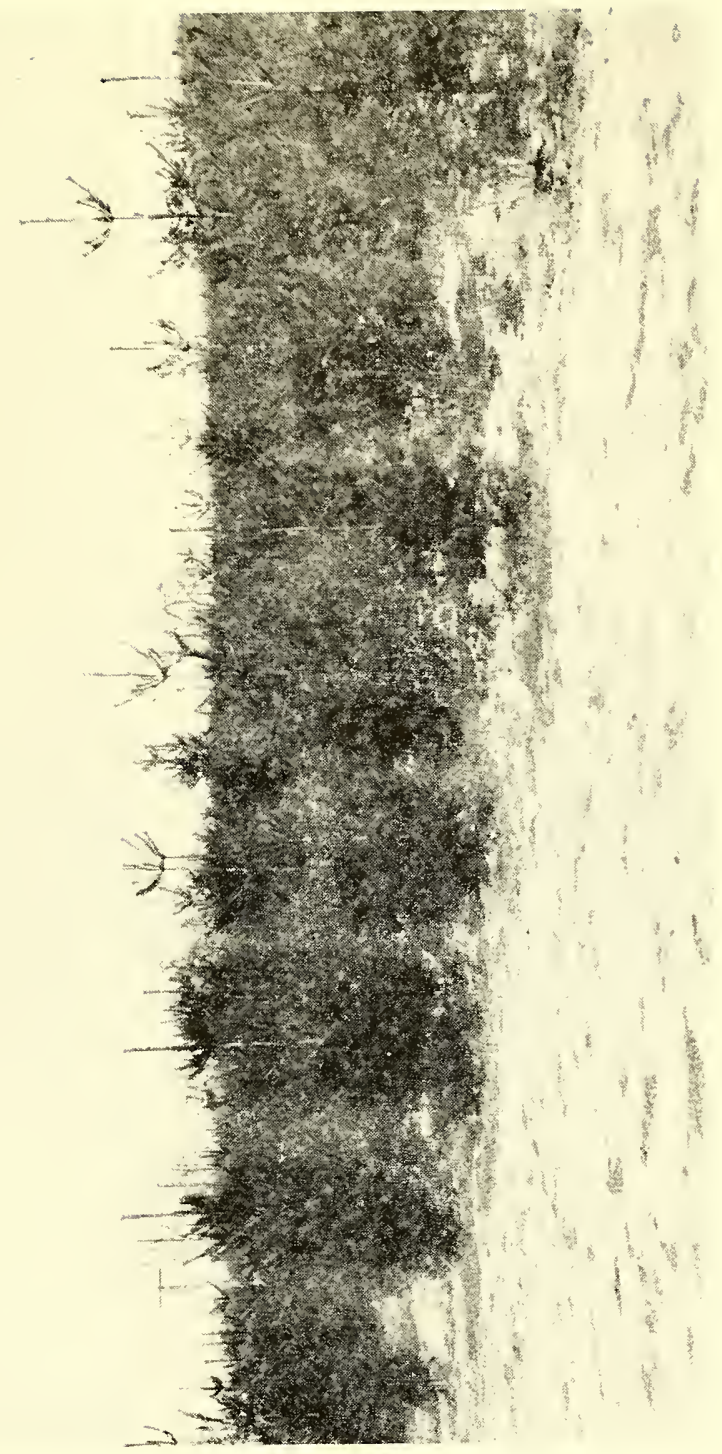




\section{PLATE 3}

A DENSE WhITE PINE PLANTATION 23 YEARS OF AGE.

No living vegetation occurs under this stand. The original spacing here, as in all white pine plantations in the Eli Whitney forest, was 6 by 6 feet. Note that the lower limbs have died but still remain on the trees. Pruning of final-crop trees, selected from the best dominant and codominant individuals, has been completed to a height of $\mathrm{I} 7$ feet above ground. One of these is the 8-inch tree in the foreground, bearing the calipers. The stand has never been thinned but is now in serious need of such a cutting. Most of the trees which should be removed are merchantable for lumber, being large enough to produce at least an 8-foot log, 6 inches inside bark at the small end. Felling the scattered trees selected for removal in a thinning is difficult in such a dense stand, particularly if done when the branches are frozen. The best method of operating is to cut the tree off at the stump and then drag it down by hitching a single horse or small tractor to the butt of the tree. 


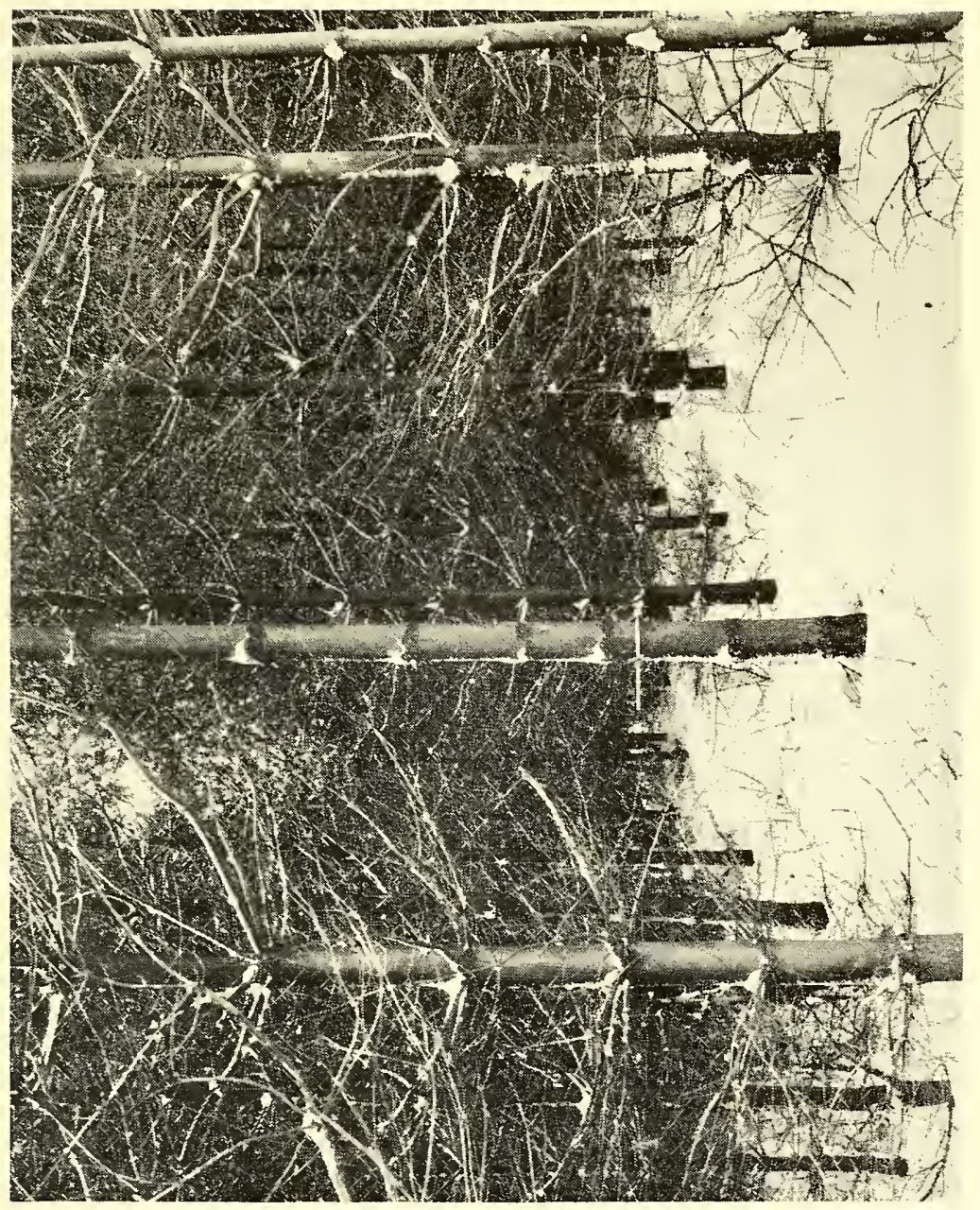




\section{PLATE 4}

WHITE PINE PLANTATION WITH PROTECTIVE BORDER OF LIVE BRANCHES EXTENDING TO THE GROUND.

The plantation is 22 years of age and is the same one as shown in Plate 2. Both pictures were taken from approximately the same point but with a period of I 5 years intervening. A perfectly maintained plantation edge adjoining a meadow is shown. The thick cover of live foliage reaching to the ground forms a wall against the entrance of wind and sun into the interior, and thereby preserves in full the protective value of the forest to the watershed. 


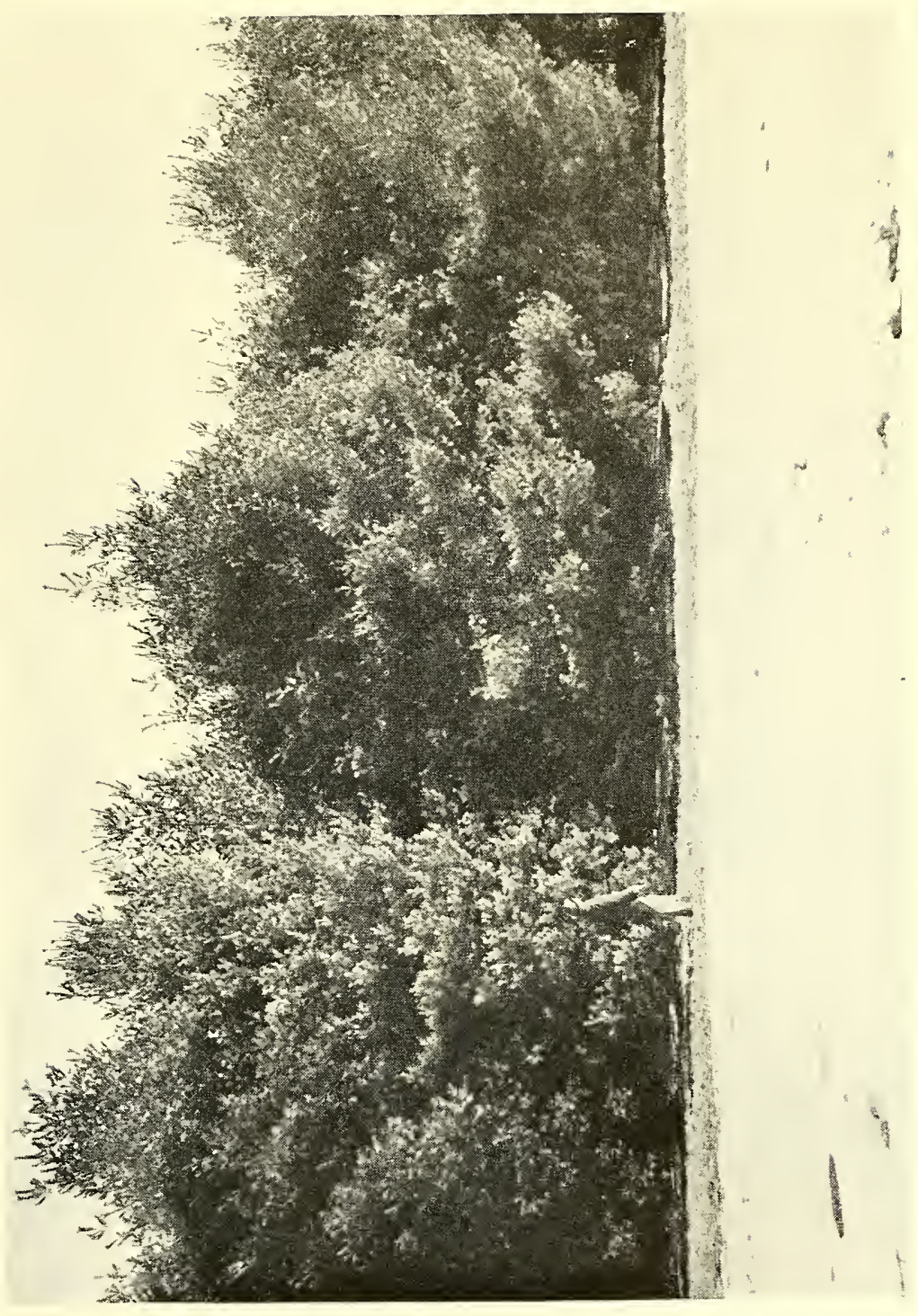




\section{PLATE 5}

WHITE PINE PLANTATION 28 YEARS OF AGE.

A thinning is needed to furnish more growing space for the pruned trees which are intended to form the final crop. The pruned tree in the foreground is 8 inches in diameter. Characteristic examples of trees badly deformed by injuries caused by the white pine weevil can be seen. There are, however, enough straight-stemmed trees to fully stock the area. The thinning which will soon be made will remove principally the larger weeviled trees. In most instances one or more merchantable logs can be cut from these weeviled trees. For example, the tree at the extreme left will be cut, and will yield two logs. 


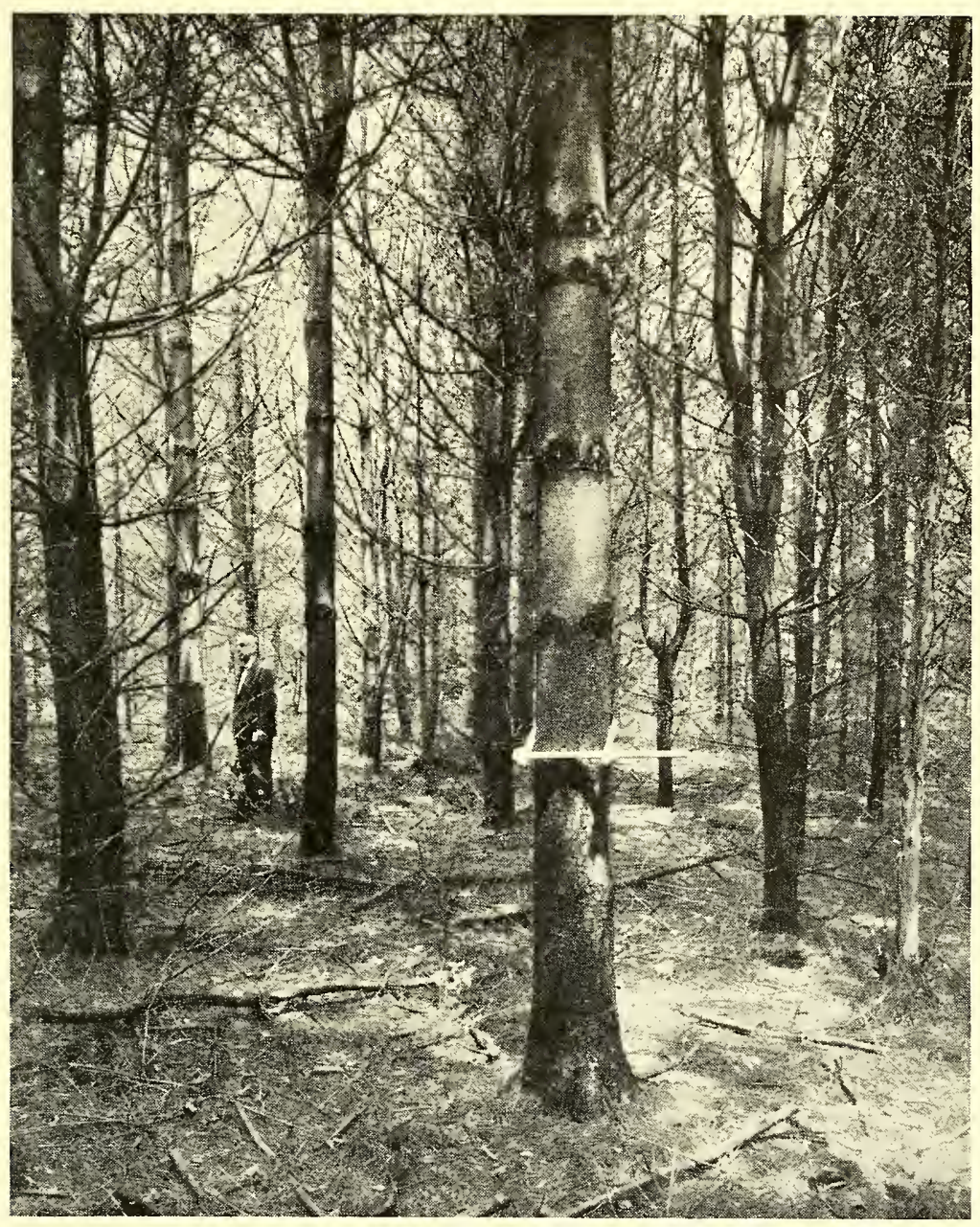




\section{PLATE 6}

A 3O-YEAR-OLD NORWAY SPRUCE PLANTATION.

Originally established with 1,200 trees per acre on a meadow with deep loamy soil, the stand still contains approximately 900 living trees per acre. The largest trees have diameters of over I I inches at breast height and total heights of 50 feet. The volume per acre is estimated to be at present approximately i 5,000 feet, board measure. No thinning has yet been made but one is needed.

The pruned tree in the foreground is one of the selected crop trees which are scattered over the area. Another pruned tree can be dimly discerned in the right background. 


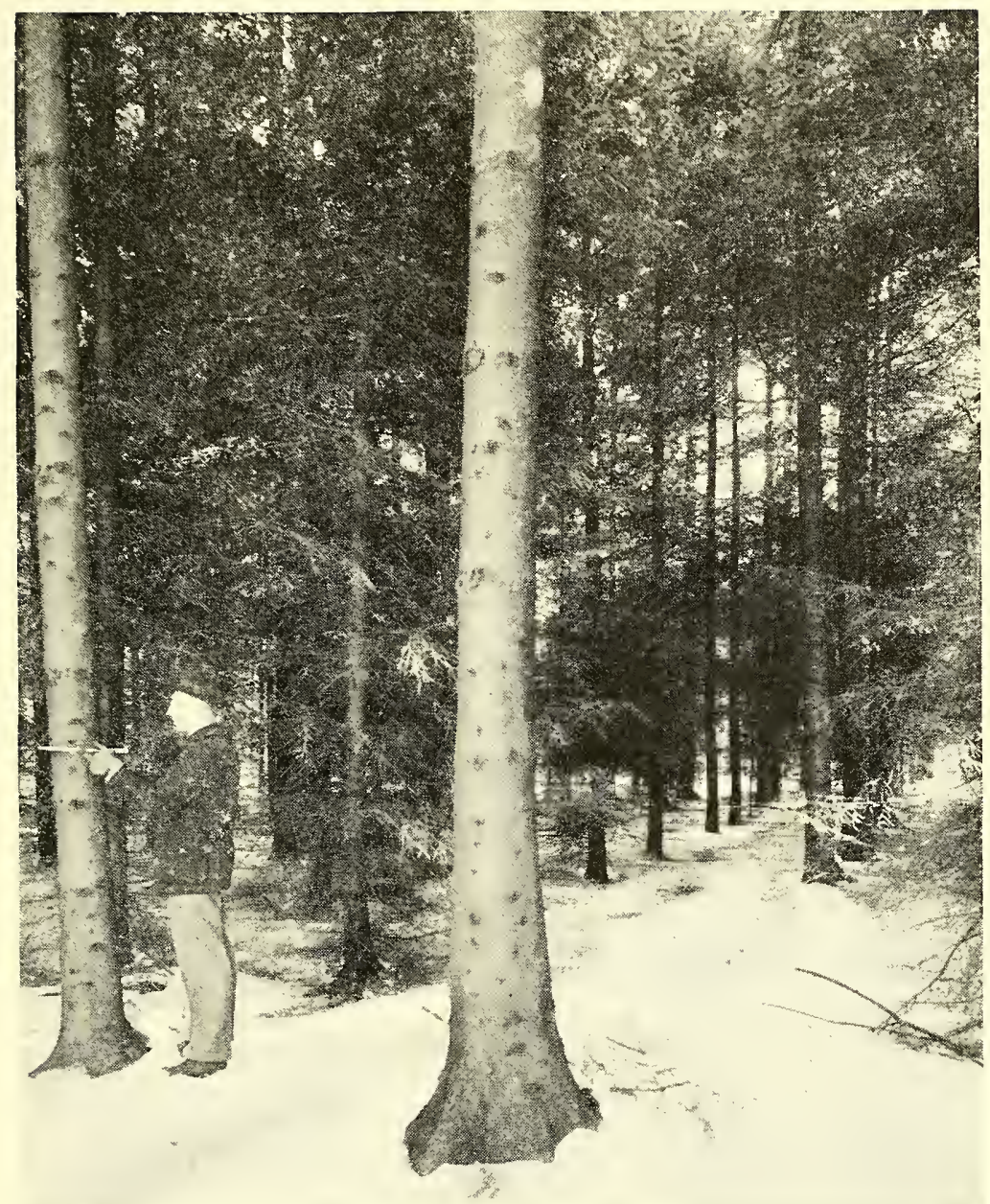




\section{PLATE 7}

WHITE SPRUCE PLANTATION 22 YEARS OLD.

White spruce probably will not grow as fast as Norway spruce, although local experience with the former species is still too meager to draw final conclusions. The open spots in the plantation are due either to small patches of hardwood shrubs and trees, which were not originally planted but have been cut back since the plantation was established, or else to wet spots where the planted trees were killed by frost heaving. 


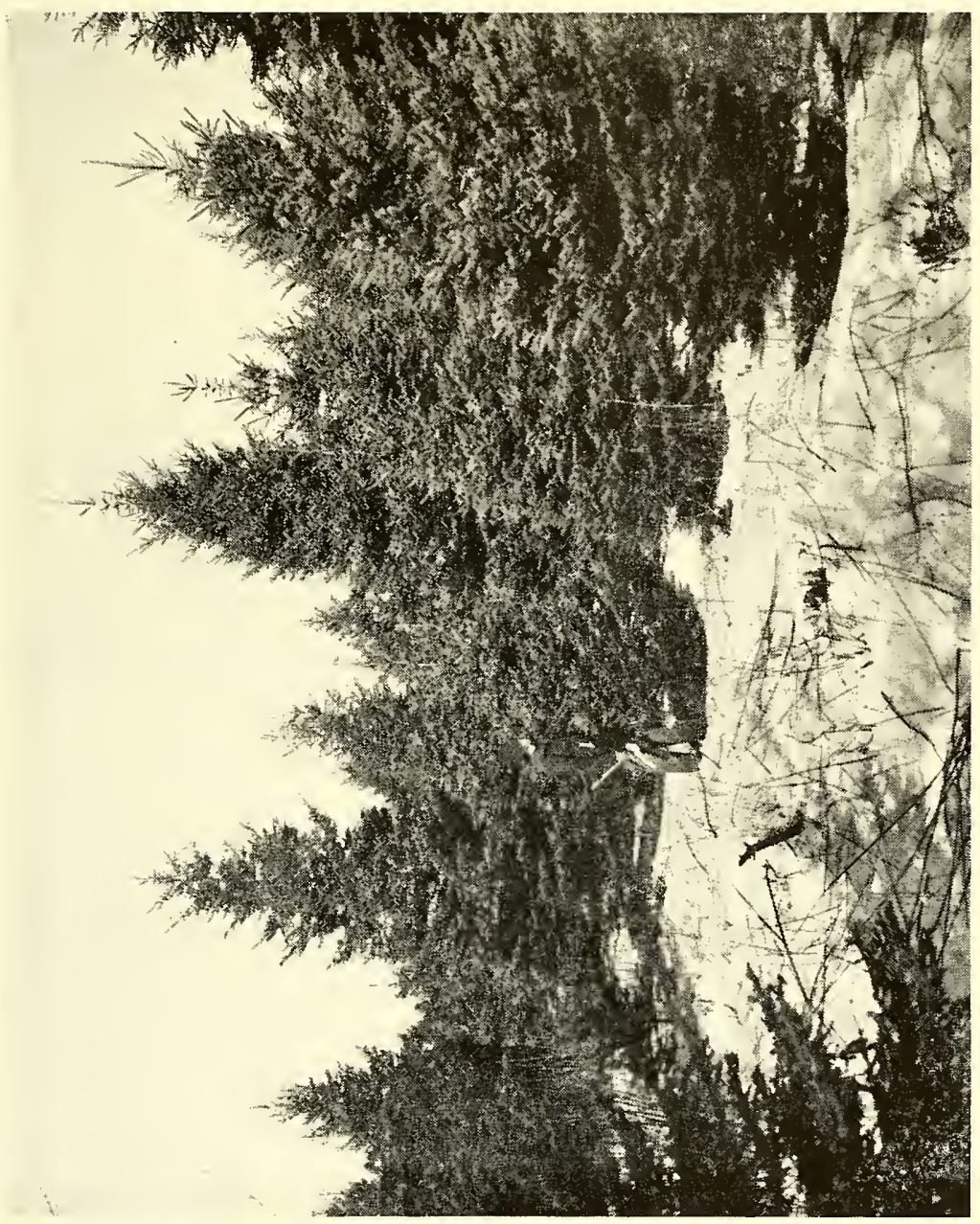




\section{PLATE 8}

A 14 -YEAR-OLD RED PINE PLANTATION HAVING AN ORIGINAL SPACING OF 6 BY 6 FEET. Out of the I,200 trees per acre planted on this former meadow I,088 per acre are still alive. On the tree in the center all branches are dead from the ground upward through the third branch whorl above the calipers. The tree is $2 \mathrm{I}$ feet in height. Artificial pruning will be required in red pine plantations if lumber free of knots is to be obtained. 


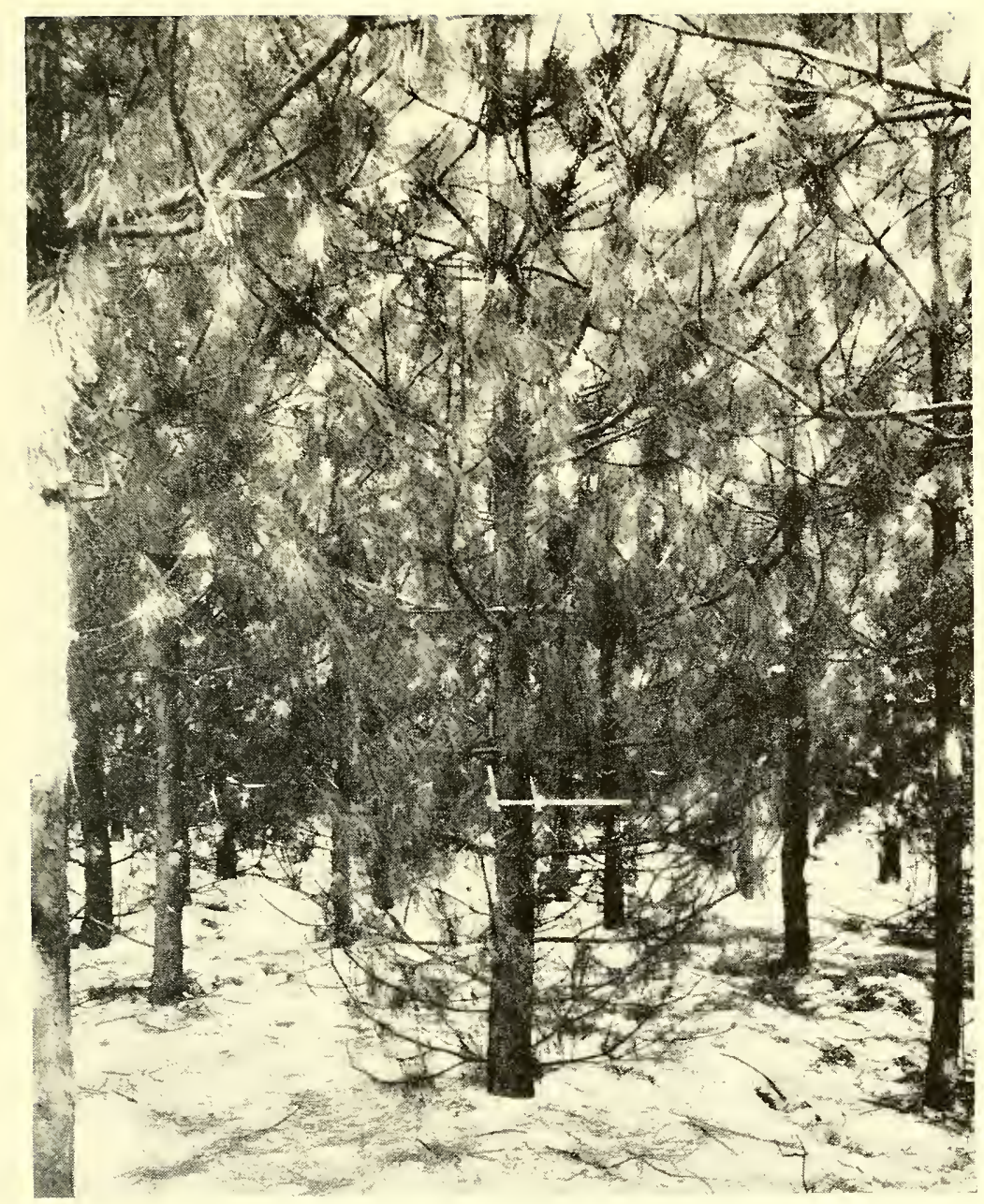




\section{PLATE 9}

RED PINE PLANTATION 28 YEARS OF AGE.

This is the same plantation as shown in Plate 8 except that a period of 14 years has passed. Number of trees has been reduced to 693 per acre as a result of natural mortality and of two thinnings. The first thinning was made 8 years ago and the second 3 years ago. The two thinnings removed 239 trees per acre. A third thinning should be made within 2 years. Living trees in the stand range from 2 to 10 inches in diameter at breast height, and dominant trees average 45 feet tall. 


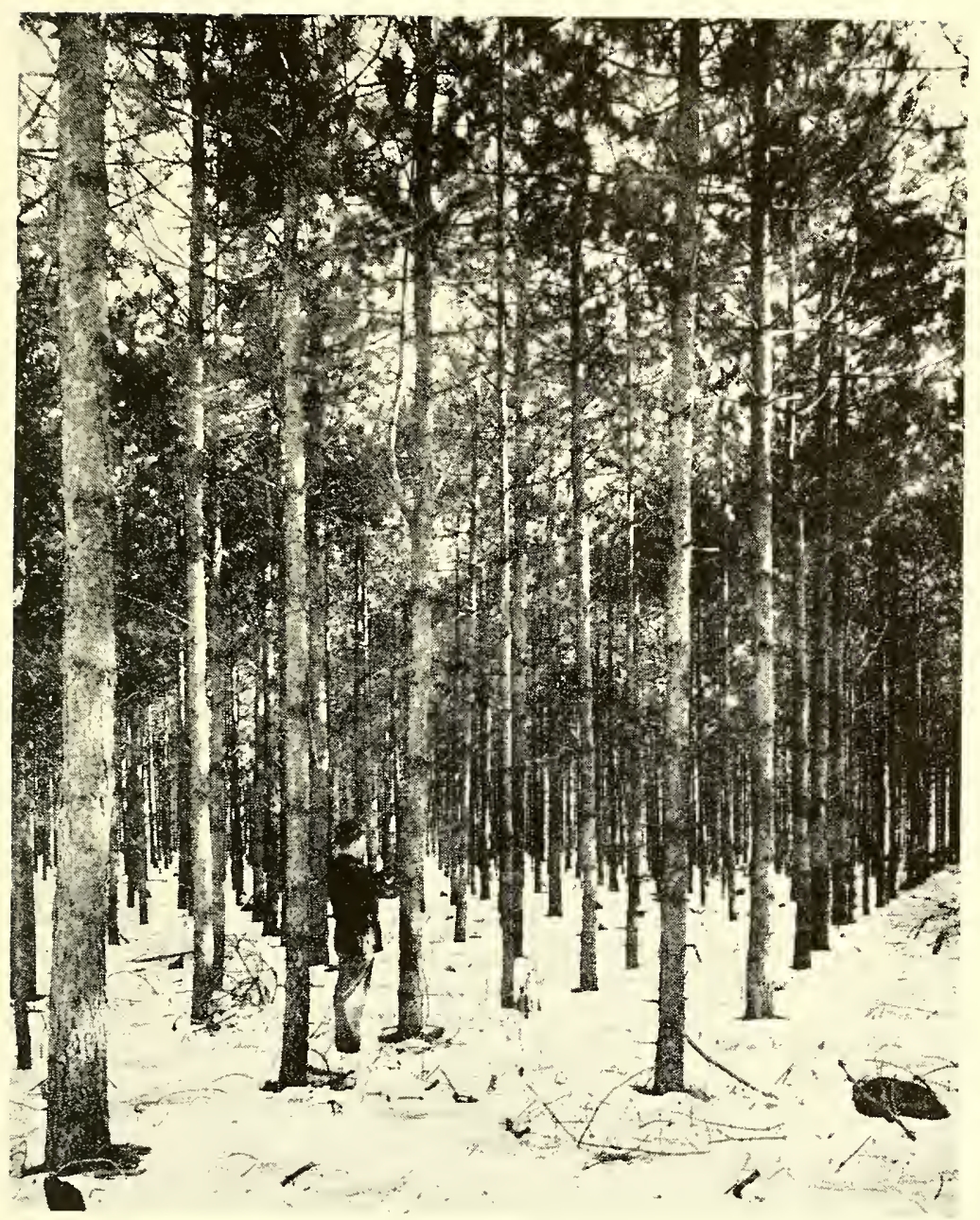




\section{PLATE IO}

RED PINE PLANTATION 6 YEARS OLD HAVING AN ORIGINAL SPACING OF́ 8 BY 8 FEET. Survival of the planted trees is Ioo per cent in the foreground and for the plantation as a whole averages 92 per cent with no gaps more than 24 feet in width. 'The man is holding an 8 -foot pole to indicate the distance between adjoining trees. The two trees at the ends of the pole are of average size for this plantation, about 3.5 feet in height. Individuals range from less than 2 to more than' 5 feet in height. 


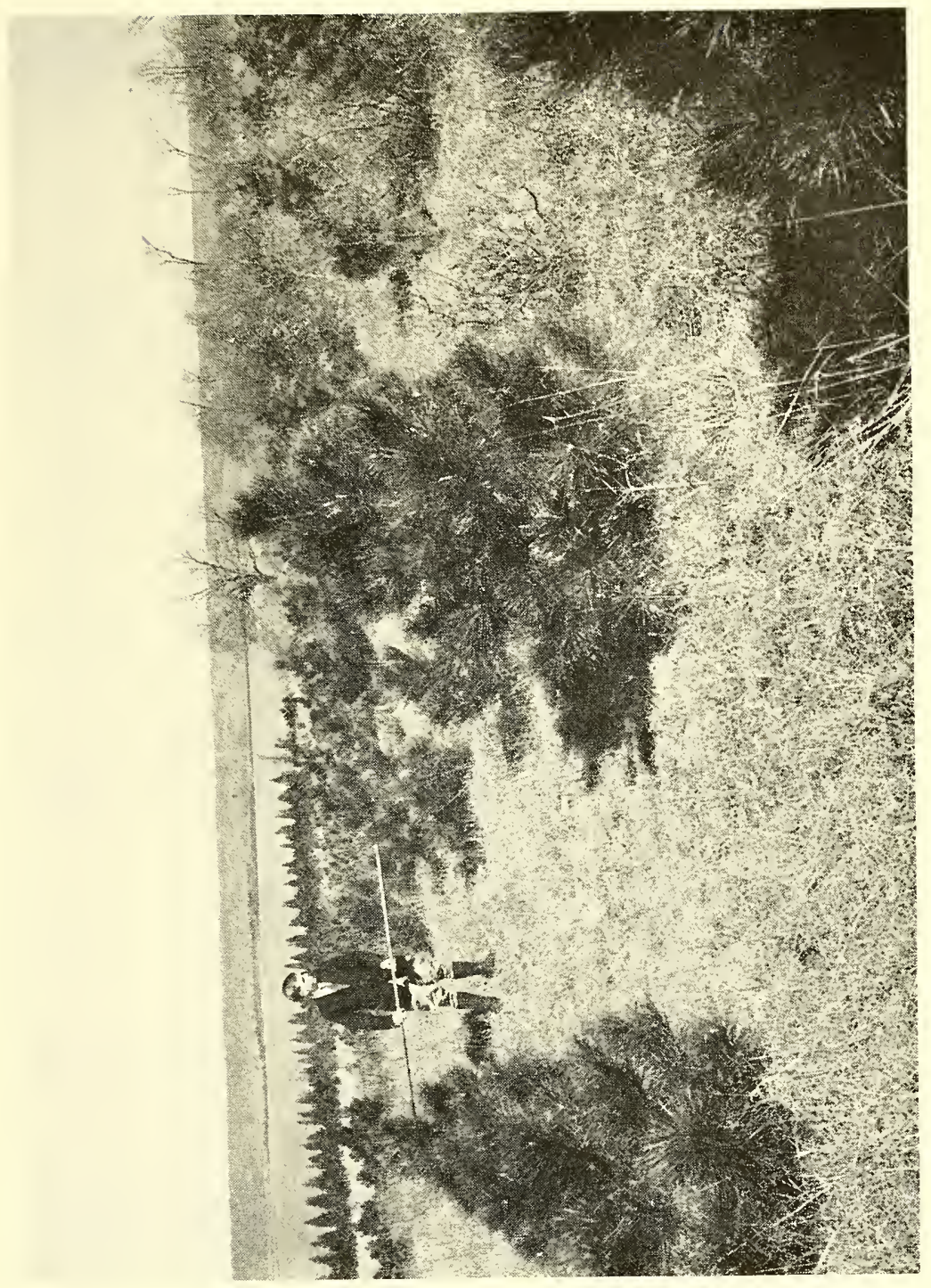




\section{PLATE II}

RED PINE PLANTATION I 2 YEARS OF AGE IN WHICH CLOSURE OF CROWNS HAS RECENTLY TAKEN PLACE.

The spacing in this plantation, made on a meadow having excellent soil, was 8 by 8 feet. Injury from the European pine shoot moth can hardly be detected, which is quite unusual. 


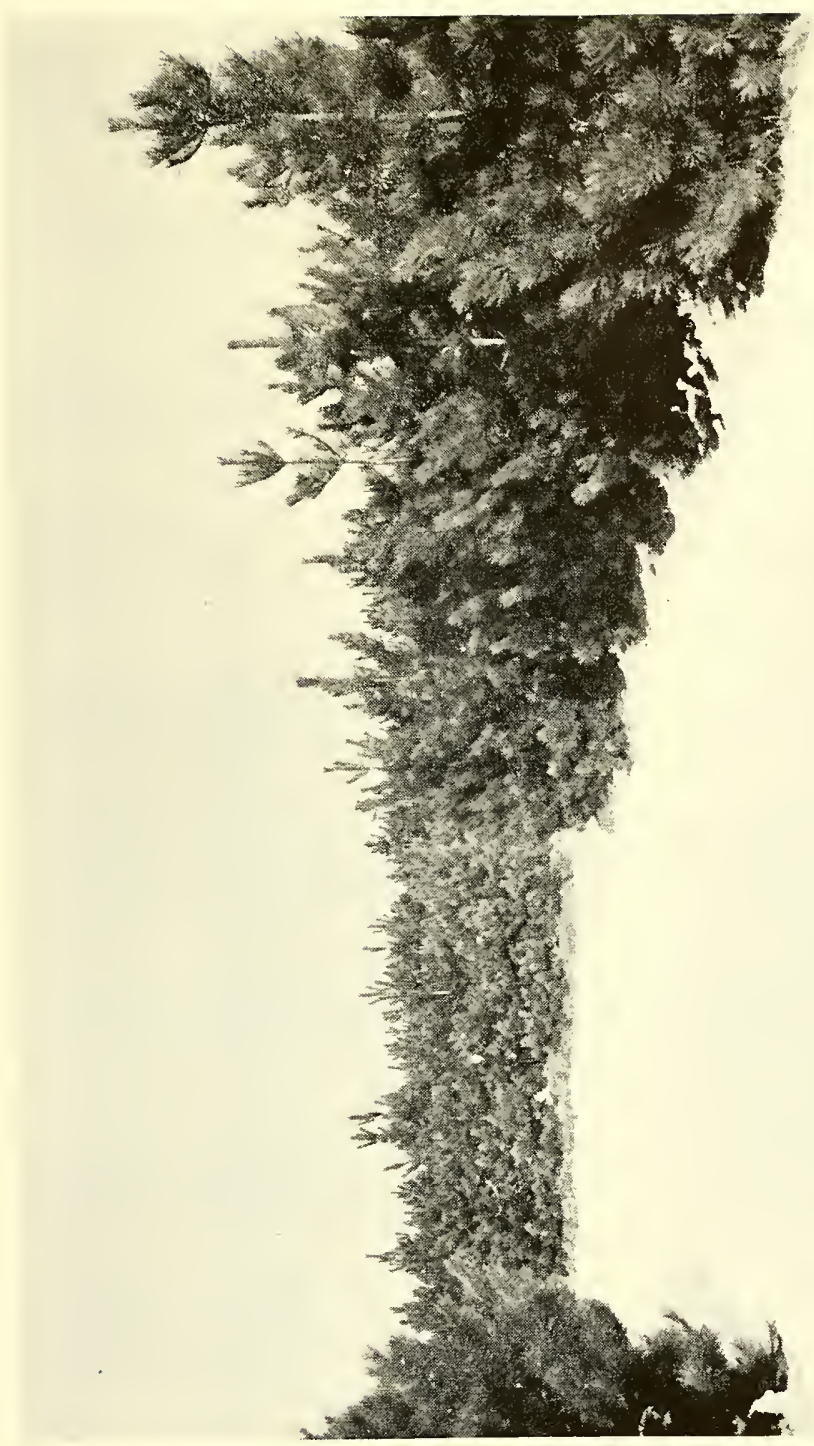


SCOTCH PINE PLANTATION 24 YEARS OLD.

A heavy thinning was made 2 years ago removing many crooked trees. Even now a number of crooked and forked trees can be seen, and several that are crooked do not show this condition in the picture. These defects are attributed principally to using seed of an inherently inferior race. Following the thinning a few of the straightest trees were pruned but it was difficult to find enough trees worth pruning to fully stock the area. The foliage, even before the stand was thinned, admitted a great deal of light to the ground. In contrast to red and white pine, and spruce plantations, a profuse reproduction of hardwood species, particularly white ash, and abundant poison ivy had started and was thriving under the Scotch pine forest. Scotch pine, however, favors the development of a very porous soil layer in excellent condition to permit rapid infiltration of water. 


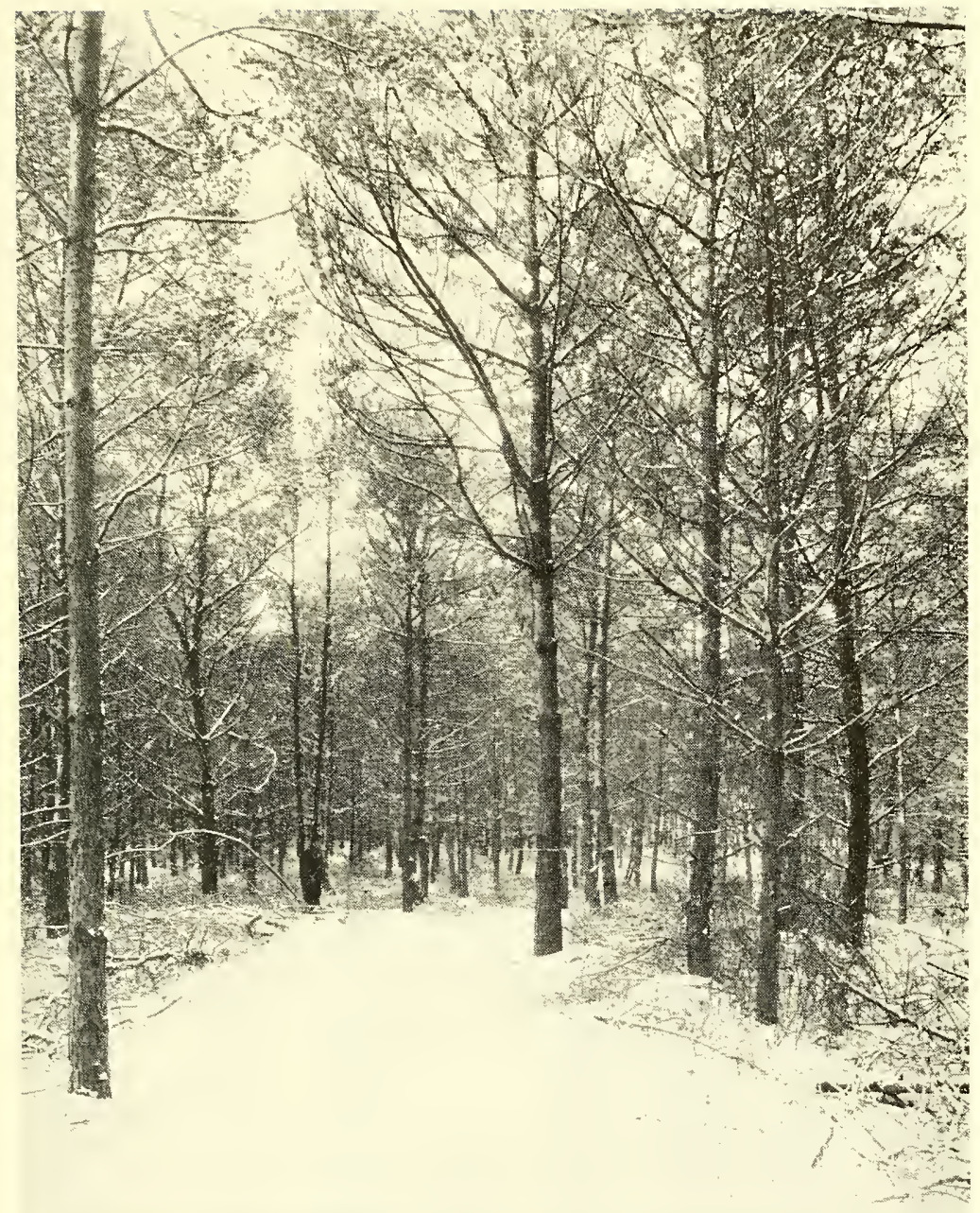




\section{PLATE I3}

A MIXED PLANTATION OF FOUR SPECIES ARRANGed in 9-TREE UNits.

This area, formerly a meadow, was planted with eastern hemlock, white pine, red oak, and spruce (both Norway and white) in groupwise arrangement. Nine-tree units of each species were used with the individual trees spaced 6 by 6 feet apart. The white pine (right background) has the greatest average height, but during the last two or three years individuals of the other three species have equaled or surpassed it in rate of growth. 


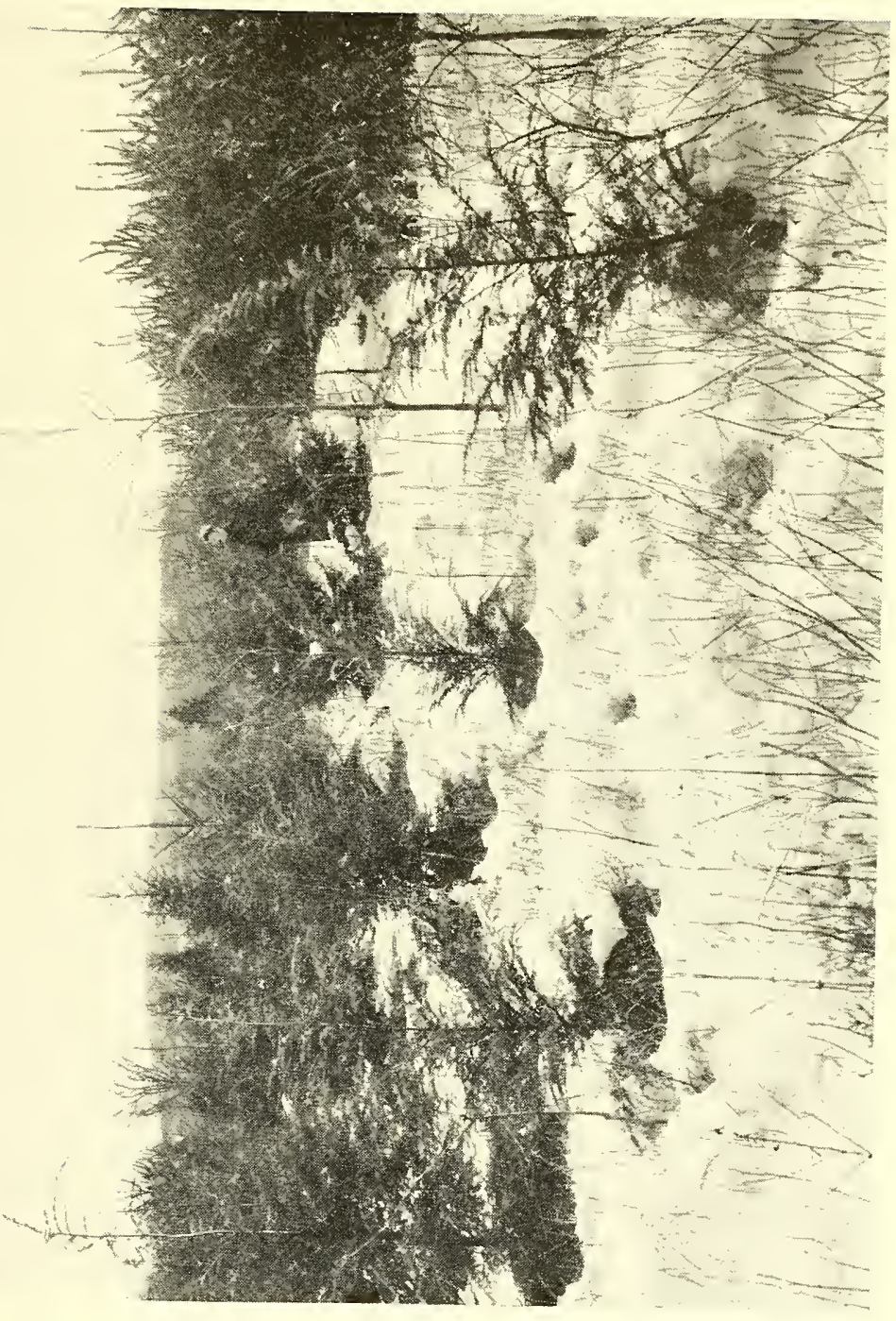




\section{PLATE I4}

RED OAK ESTABLISHED BY DIRECT SEEDING.

A 20-year-old stand of red oak which was established by planting acorns at intervals of 6 by 6 feet. Two or 3 acorns were put in each hole. The tree calipered is 4 inches in diameter at breast height and approximately $3 \circ$ feet tall. The site at the time of direct seeding was a closely grazed pasture of medium to poor quality. Compare with Plate 25 taken 15 years later in the same stand. 


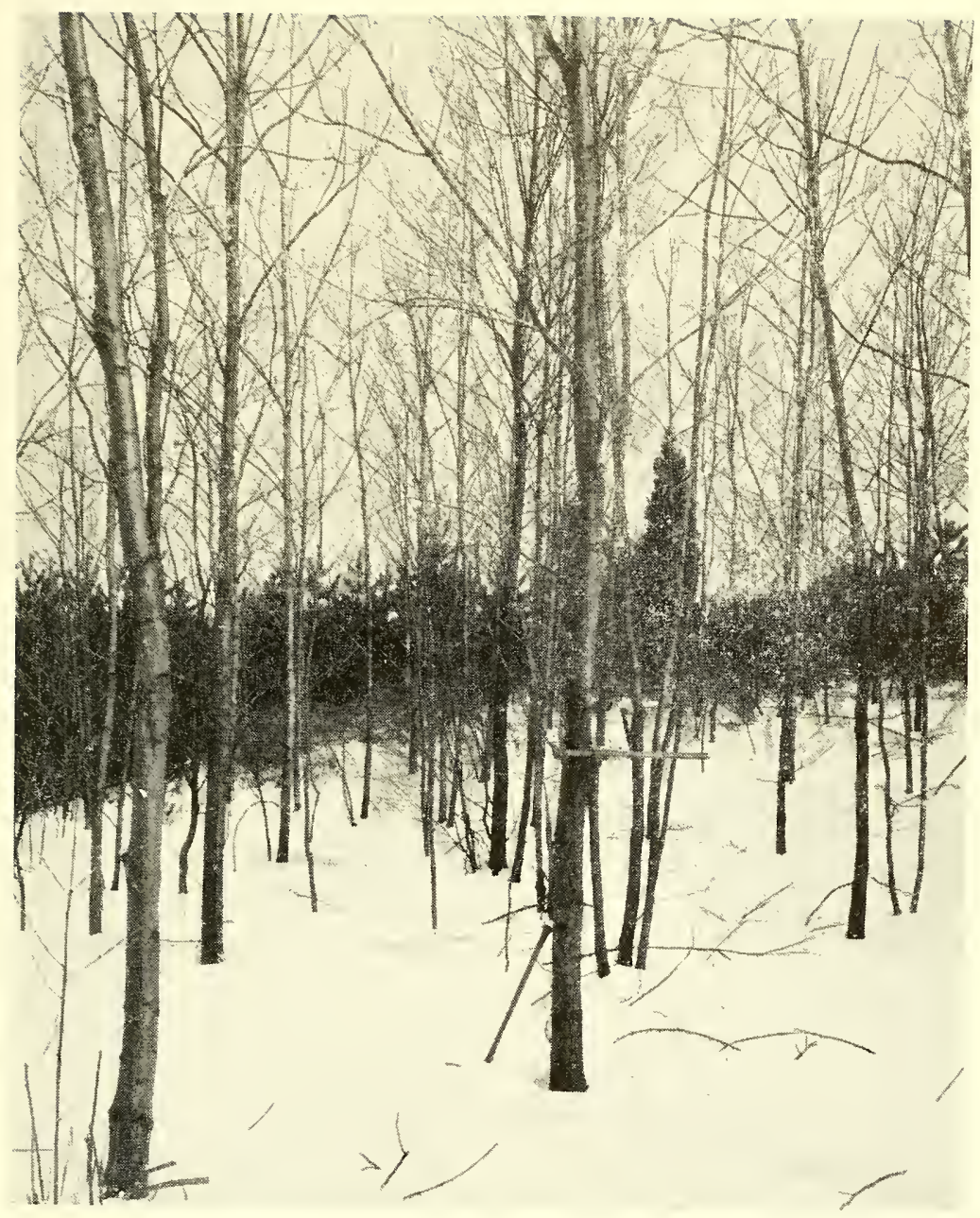




\section{PLATE I 5}

RED PINE TREE, IO YEARS OLD, THAT HAS JUST BEEN PRUNED TO A HEIGHT OF 7 FEET. An illustration of a first pruning operation in a young plantation. Selected trees have been pruned to the height of the highest point of interlacing of the crowns, which in this stand is about the height to which a man standing on the ground can reach conveniently with a hand saw. 


\section{PLATE I6}

RED PINE TREE, I 5 YEARS OLD, THAT HAS BEEN PRUNED TO A HEIGHT OF I7 FEET. The tree in the center foreground has just received its third pruning, completing the operation to a height of I 7 feet. Two whorls of branches were removed in the last pruning. A hand saw and ladder were used in the operation. 
PLATE 17

A WHITE PINE TREE PRUNED TO A HEIGHT OF 18 FEET IN TWO OPERATIONS.

Light-colored stubs indicate the whorls removed in the second pruning. Although most of the branches in the highest three whorls removed were alive, the pruning does not extend above the highest point of interlacing of the live crown with those of adjoining trees. 


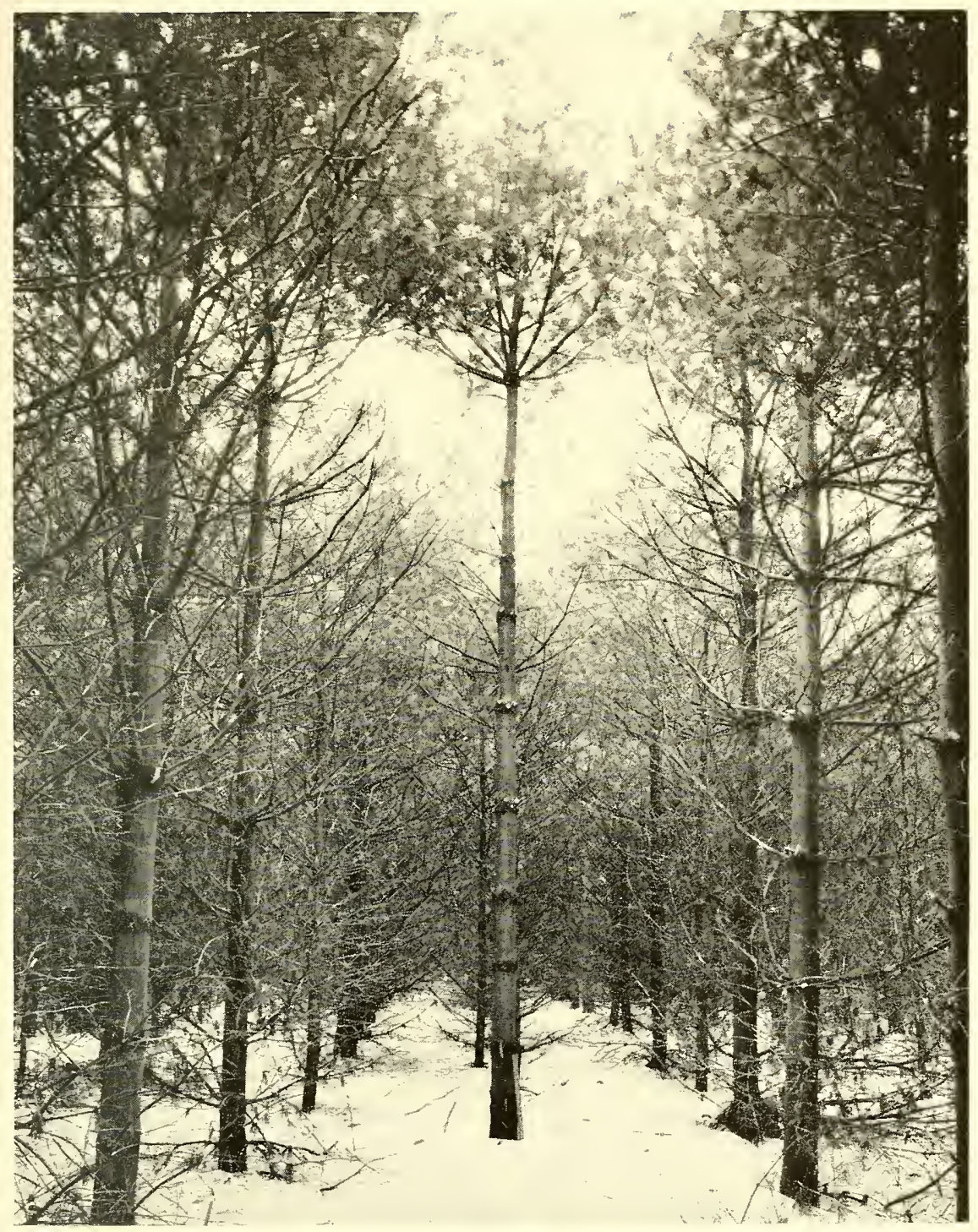


PLATE 18

PRUNING BY THE SAW AND LADDER METHOD.

The man is using a curved pruning saw with a I 4 -inch single-edge blade. The ladder is 8 feet long. With a ladder of this leng th it is possible to prune to a height of $I_{3}$ to $I_{4}$ feet. For pruning to $I_{7}$ feet a $I_{2}$-foot ladder is desirable. 


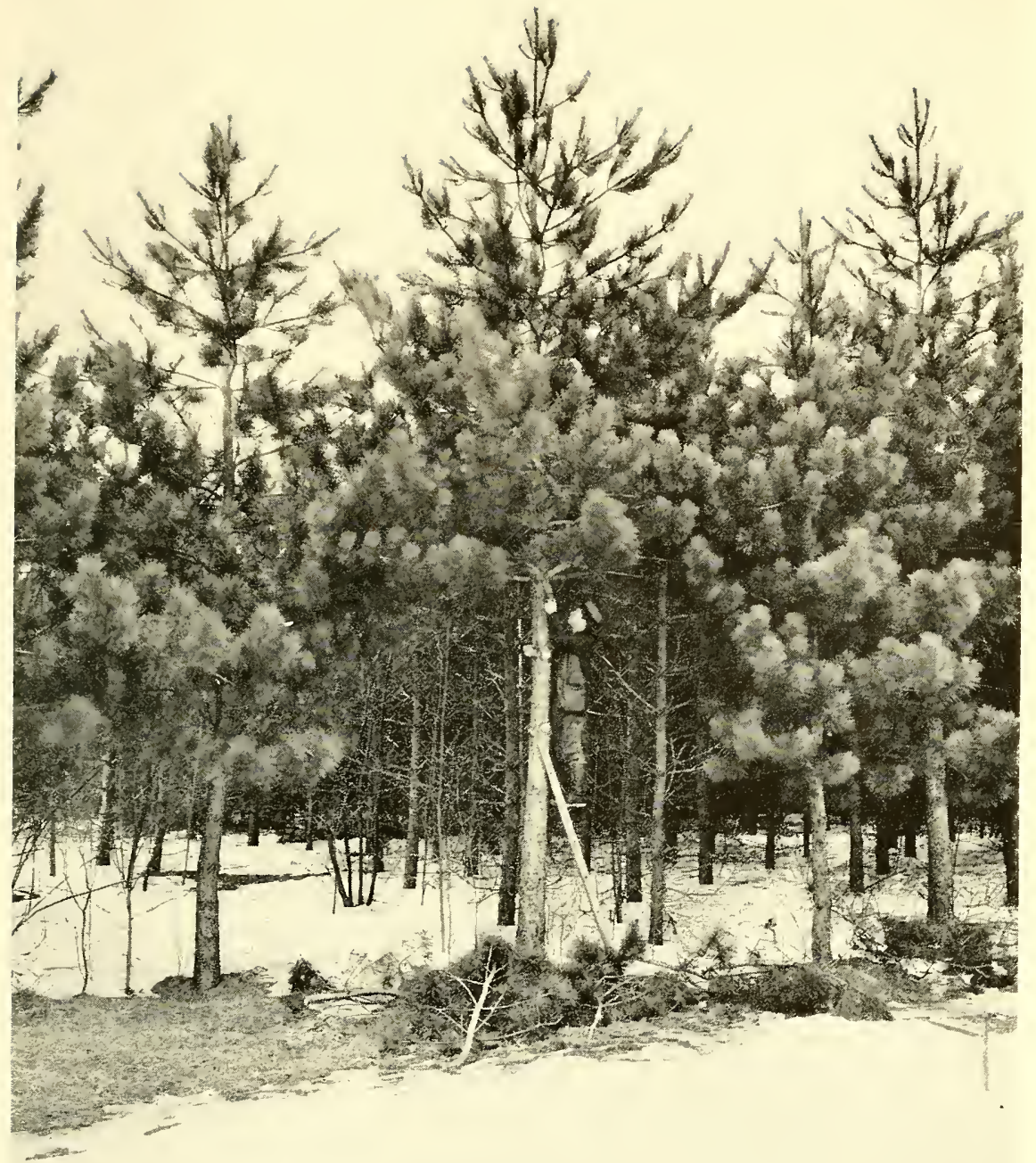




\section{PLATE I9}

TWO VIEWS THROUGH A PRUNED WHITE PINE BRANCH STUB.

A good example of complete covering of a pruned stub with practically no bark and pitch pocket. There is a thin line of pitch covering the stub but the accumulation of bark and pitch extends, at its greatest thickness, less than 0.2 of an inch beyond the face of the cut. The dark vertical line through the center of the lower view indicates where the section was sawed to expose the face shown in the top view. The diameter growth made after pruning was too slow as the tree was crowded by its neighbors. 

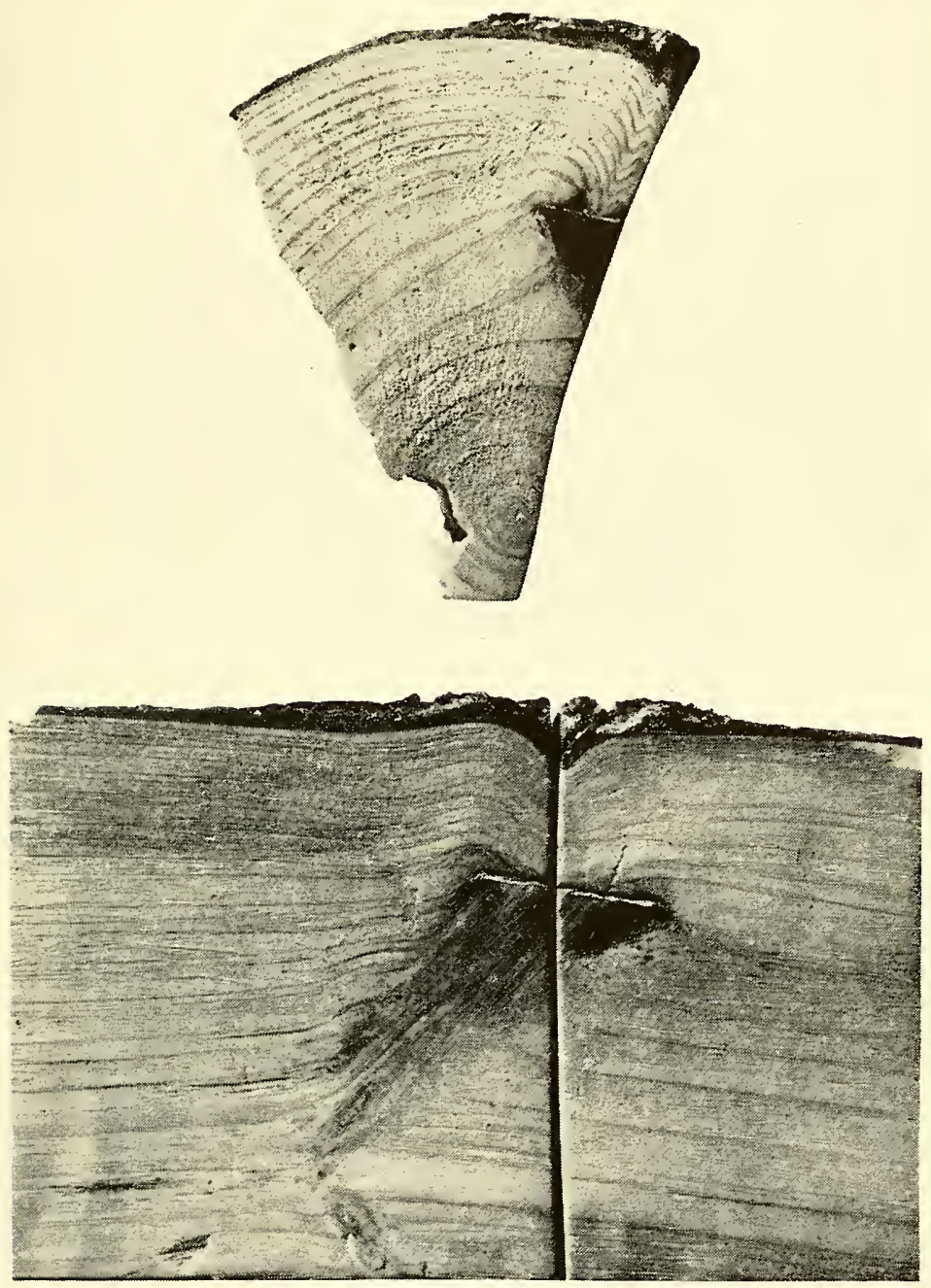


\section{PLATE 20}

ZONE OF CLEAR WOOD FORMED OVER PRUNED BRANCH STUBS.

During the last I 6 years clear wood has been formed over these stubs. In the lower view the clear wood has a radial width of 2.8 inches which represents a satisfactory growth rate. In the upper view only I.3 inches of clear wood has been formed, which is too slow a grow th rate to justify the expense of pruning. Evidently a thinning should have been made to stimulate diameter growth on the tree from which the upper section was taken. 

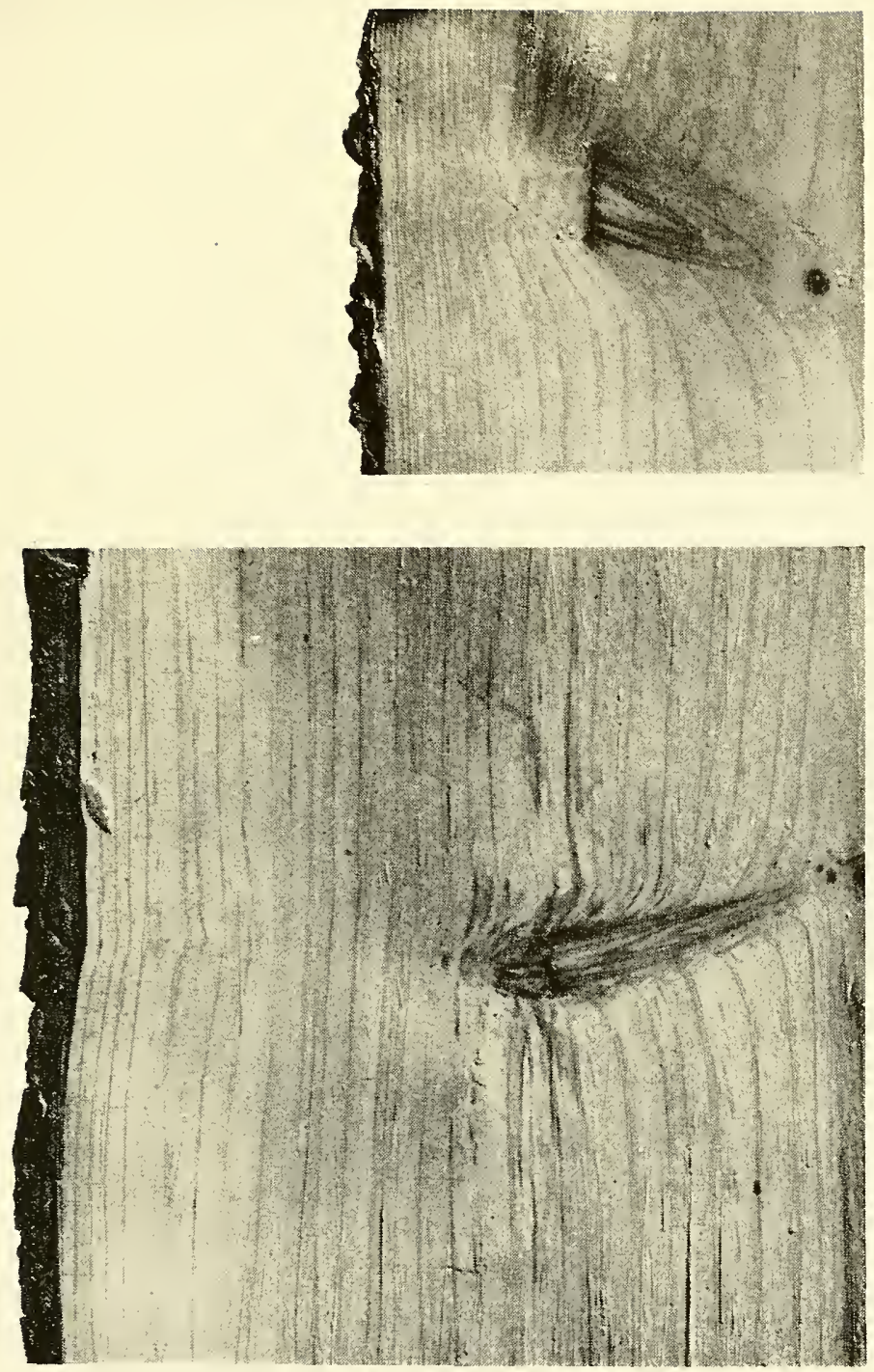
PLATE 2I

A BARK AND Pitch POCKET ENCLOSED ON A COMPLETELY COVERED WHite PiNe BRANCH STUB.

Large bark and pitch pockets occasionally may be found adjoining the face of healed-over pruned branch stubs. Such pockets are of course defects in the wood, but should be considered as belonging with the central knotty core in the log rather than as forming a part of the outer zone of clear wood. In estimating the size of the central knotty core an allowance of one inch radially on each side of the core is added to take care of bark and pitch pockets such as shown in this Plate. Actually the radial width of this particular bark and pitch pocket is only one-half inch and the growth of this section has been very slow. It is believed that slow growth after pruning is responsible for developing larger bark and pitch pockets than would be produced when a fast growth rate is maintained. 


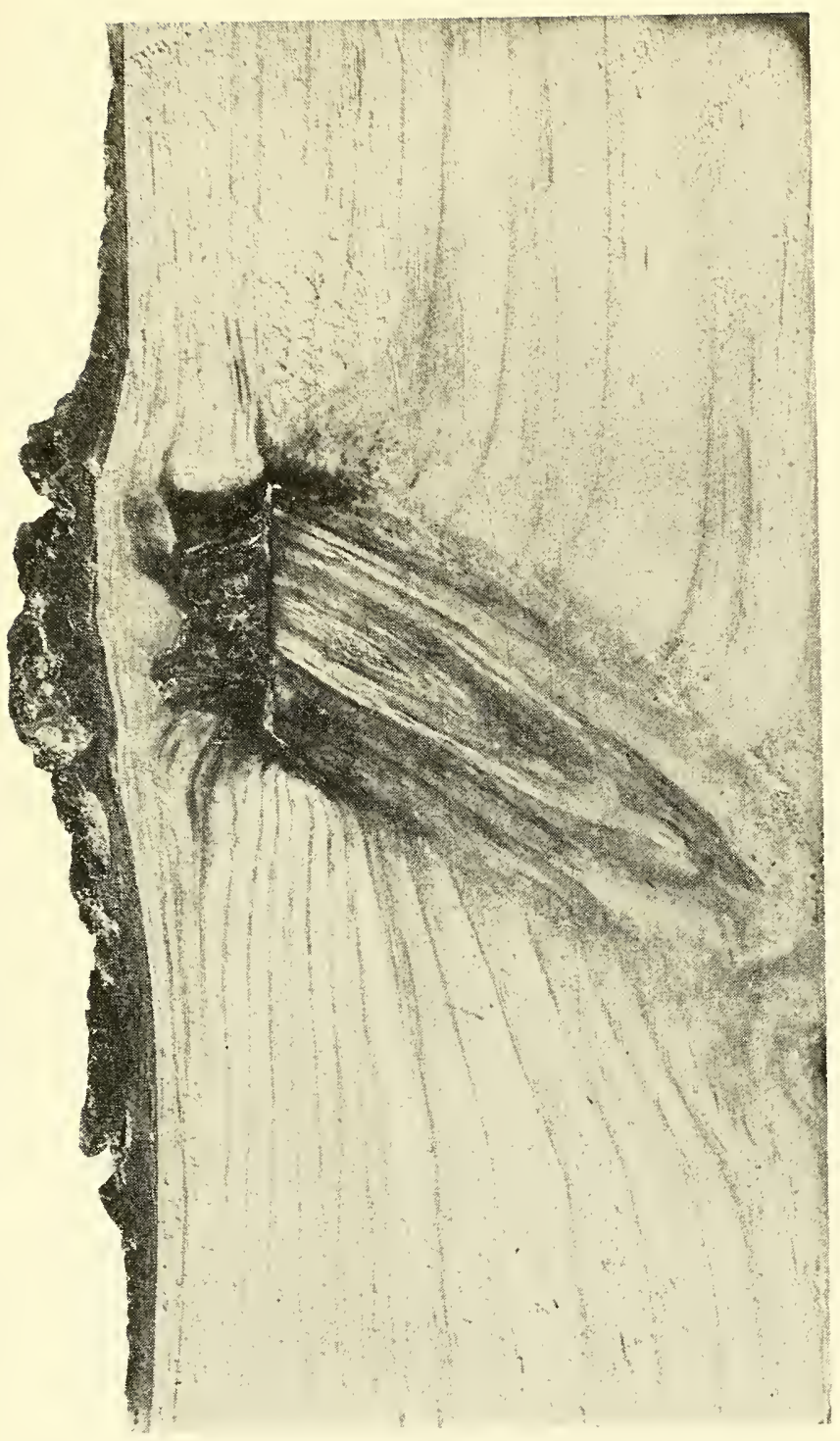




\section{PLA'TE 22}

WHITE PINE PLANTATION, 23 YEARS OF AGE, AFTER A FIRST THINNING.

The thinning removed only trees, containing at least one merchantable log, which were crowding the pruned trees. The primary object of the thinning was to stimulate rapid growth in the pruned trees. Lumber obtained from the trees cut in the thinning was approximately I,750 feet, board measure, per acre. The calipered tree at the left is 10 inches in diameter at breast height. 


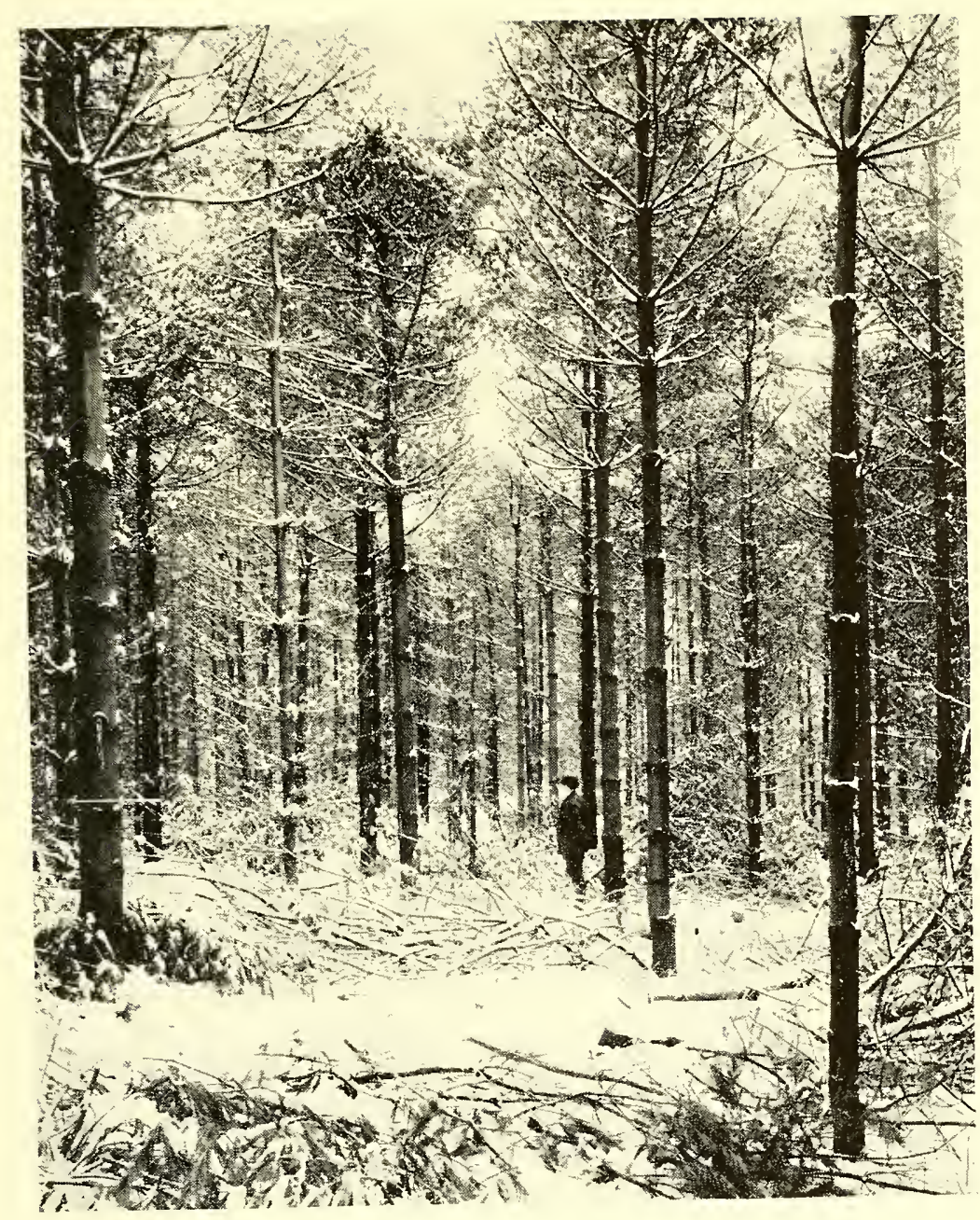




\section{PLATE 23}

WHITE PINE PLANTATION THINNED 7 YEARS AGO.

This plantation was established 32 years ago on a site of excellent quality for growth of white pine. Seven years ago a thinning was made removing merchantable trees which were crowding the pruned trees. Another thinning is needed now. Too many trees per acre were pruned in this stand. As a consequence one or two of the pruned trees shown in this picture may have to be taken out in the next or subsequent thinnings. Number of trees in this stand will be reduced to 60 to 80 per acre (all pruned) before the end of the 6o-year rotation. The four pruned trees in the foreground and center range from 9 to $\mathrm{I} 2$ inches in diameter. 


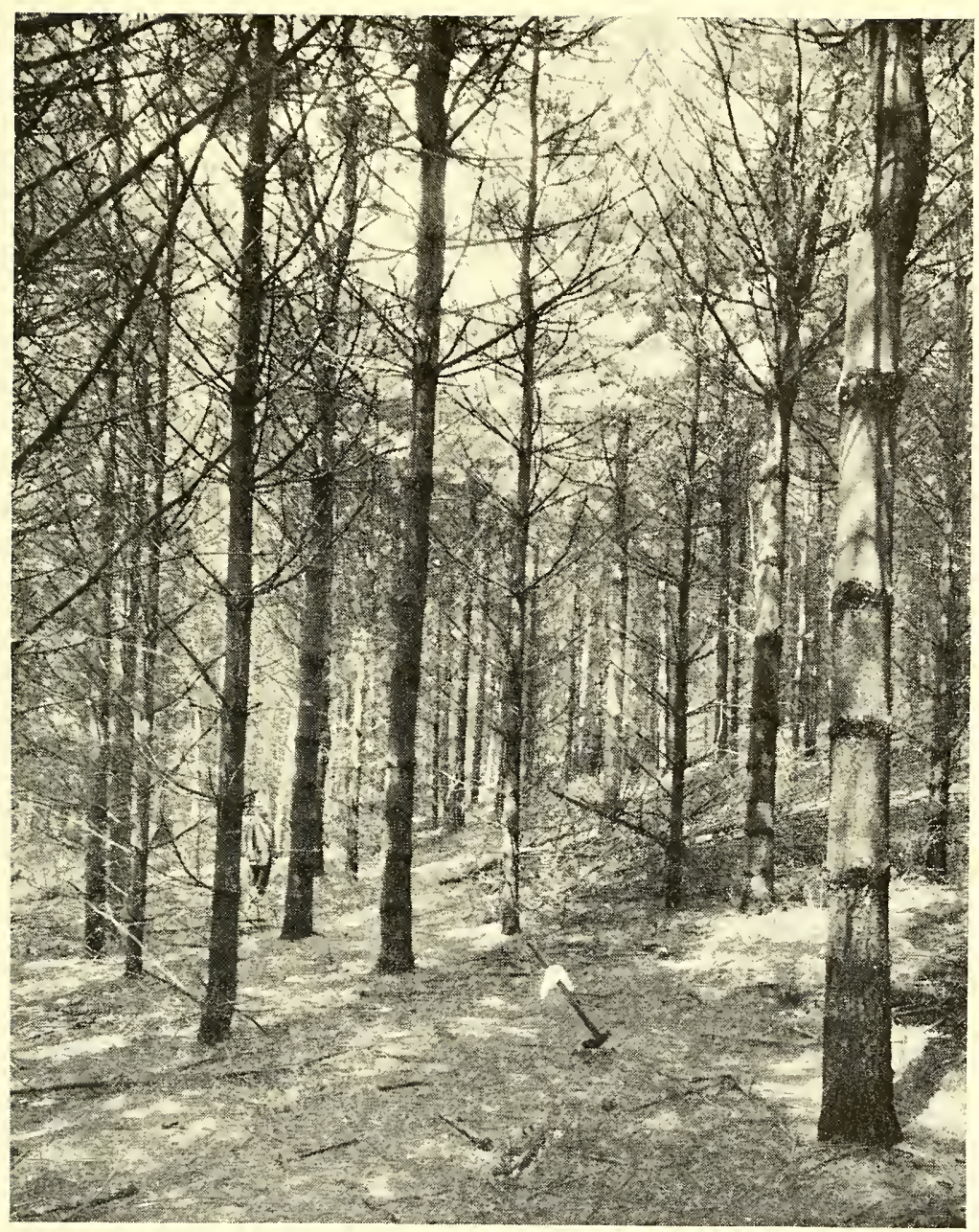




\section{PLATE 24}

NORWAY SPRUCE PLANTATION, 30 YEARS OLD, AFTER A FIRST THINNING.

This stand was thinned about 9 months before the picture was taken. The thinning removed 177 trees per acre from among the smaller size classes ( 4 to 6 inches in diameter at the ground) for oyster buoys. There remain 734 living trees per acre ranging in diameter from 3 to I I inches. Compare with Plate 6 which shows another part of this same stand which was not thinned. 


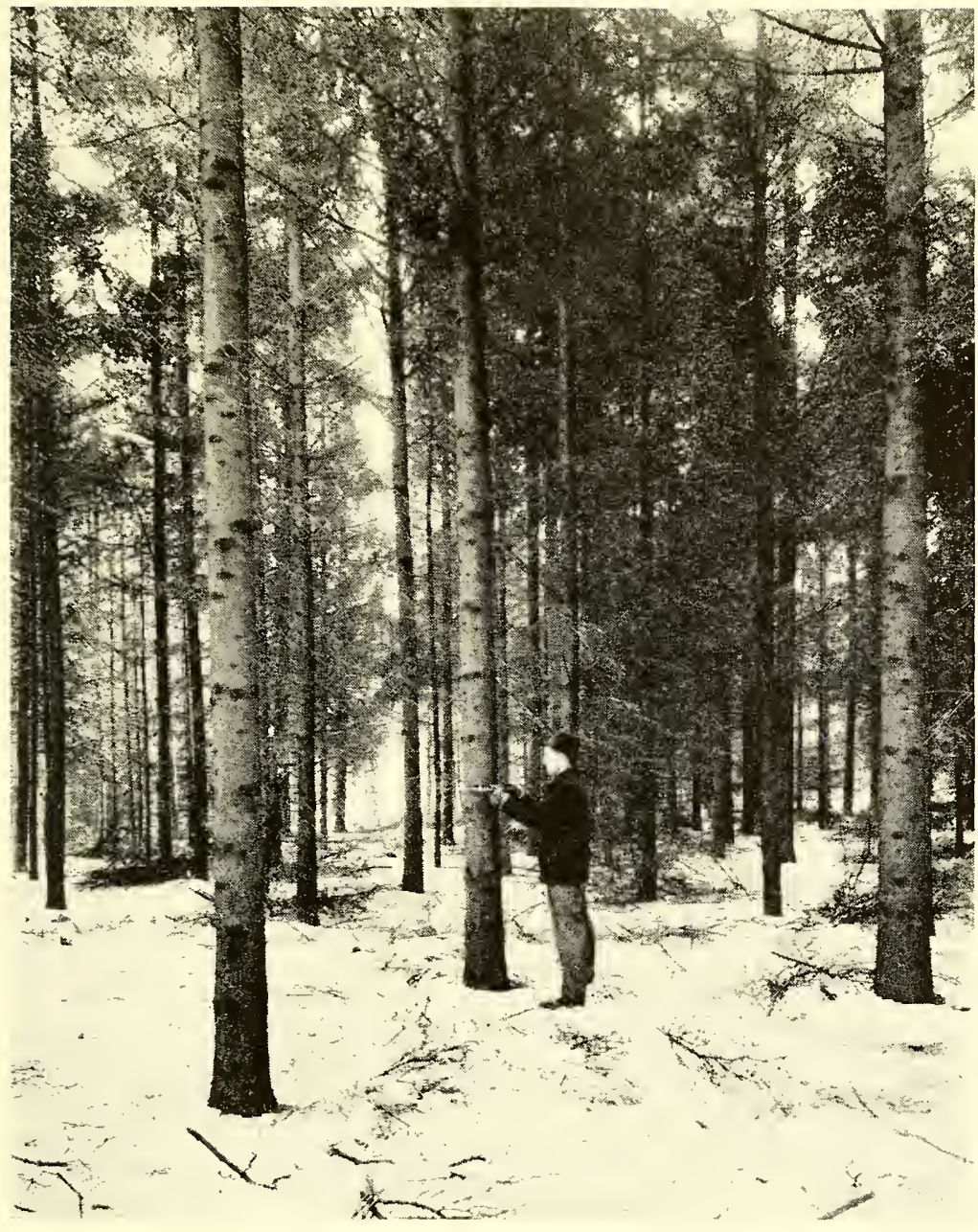




\section{PLATE 25}

RED OAK ESTABLISHED BY DIRECT SEEDING 35 YEARS AGO AND RECENTLY THINNED. The dominant trees are 50 feet in height and those in the foreground and left center are 7 to 9 inches in diameter. A thinning just completed removed approximately 6 cords of fuelwood per acre. The site is about medium for tree growth.

Plate I 4 shows the same stand when 20 years of age. 


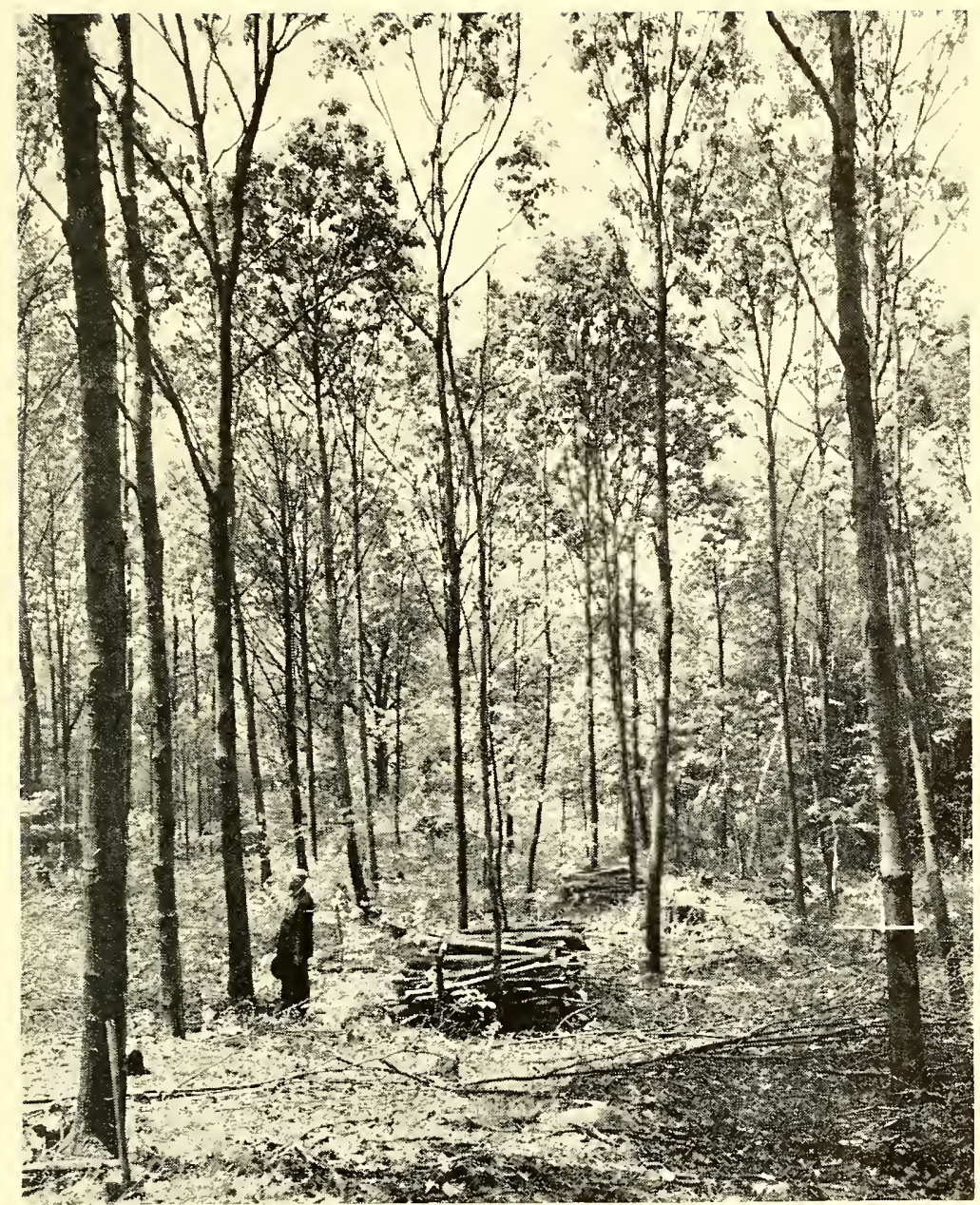







University of

Connecticut

Libraries 
